\title{
ipen
}

AUTARQUIA ASSOCIADA À UNIVERSIDADE DE SÃO PAULO

CARACTERIZAÇÃO MICROESTRUTURAL E MECÂNICA DE UMA LIGA DE CO-CR. UMA AVALIAÇÃO DE SEU DESEMPENHO MECÂNICO EM UM PRODUTO DE ENGENHARIA

DIÓGENES CORDEIRO DE SOUZA NETO

Dissertação apresentada como parte dos requisitos para obtenção do Grau de Mestre em Ciências na Área de Tecnologia Nuclear - Materiais

Orientadora:

Prof. Dr. Waldemar Alfredo Monteiro 
INSTITUTO DE PESQUISAS ENERGÉTICAS E NUCLEARES

Autarquia associada à Universidade de São Paulo

\section{CARACTERIZAÇÃO MICROESTRUTURAL E MECÂNICA DE UMA LIGA DE CO-CR. UMA AVALIAÇÃO DE SEU DESEMPENHO MECÂNICO EM UM PRODUTO DE ENGENHARIA}

DIÓGENES CORDEIRO DE SOUZA NETO

Dissertação apresentada como parte dos requisitos para obtenção do Grau de Mestre em Ciências na Área de Tecnologia Nuclear - Materiais

Orientador:

Prof. Dr. Waldemar Alfredo Monteiro

Versão Corrigida

Versão Original disponível no IPEN

São Paulo

2014 


\section{DEDICATÓRIA}

\section{A Deus}

Pela ajuda nos momentos difíceis, pela saúde e bênçãos.

\section{A minha família}

Pelo amor incondicional, e pelo incentivo

\section{Ao Dr. Spero}

Que mesmo depois de interromper as atividades da Innovatech(empresa que fabricava os Stents) e deu origem ao trabalho, continuou dando apoio material e moral para que o trabalho pudesse ser concluído.

\section{Aos meus orientadores}

\section{Dr. Arnaldo e Dr. Waldemar}

Primeiro que me aceitou como aluno possibilitado o início e desenvolvimento do trabalho, o segundo por ter aceitado assumir formalmente minha orientação e pela ajuda para finalizar o trabalho. 


\section{AGRADECIMENTOS}

Ao Centro de Ciências e Tecnologia dos Materiais (CCTM), por permitir o acesso aos equipamentos e laboratórios fundamentais para o desenvolvimento dos trabalhos.

À Innovatech que forneceu o material a ser estudado, equipamentos e insumos utilizados no trabalho.

Ao Djalma do Centro de Tecnologia das Radiações (CTR) que permitiu a utilização do equipamento de ensaio de tração no momento que o equipamento do CCTM estava ocupado com outro estudo.

Ao Allan pelos conselhos apoio moral e ajuda com a redação do trabalho

Ao laboratório de filmes finos da USP pela possibilidade de analisar amostras durante aulas da Prof. Cecília.

Ao Conselho Nacional de Desenvolvimento Científico e Tecnológico (CNPQ) que financiou minha bolsa de estudos

Ao Instituto de Pesquisas Energéticas e Nucleares que de modo geral possibilitou que todo o trabalho fosse realizado 


\title{
CARACTERIZAÇÃO MICROESTRUTURAL E MECÂNICA DE UMA LIGA DE CO-CR. UMA AVALIAÇÃO DE SEU DESEMPENHO MECÂNICO EM UM PRODUTO DE ENGENHARIA
}

\author{
Diógenes Cordeiro de Souza Neto
}

\begin{abstract}
RESUMO
Este estudo foi desenvolvido no Instituto de Pesquisas Energéticas e Nucleares IPEN mais especificamente, no Centro de Ciência e Tecnologia dos Materiais CCTM com apoio da empresa Innovatech. Foram estudados tubos de Co-Cr (L605) usados para fabricação de stents coronarianos, aplicação esta que pede um comportamento mecânico específico e biocompatibilidade. Os tubos de $\mathrm{CoCr}$ (L605) podem ser adquiridos em duas condições de história térmica: Trabalhado a frio ou com encruamento ou recozido. O tubo recozido se não estiver em condições para a aplicação, dificilmente será possível atingi-las com um novo tratamento térmico. O tubo encruado abre possibilidades para acertar as condições de tratamento térmico e obter a condição ideal de comportamento mecânico, sem comprometer outros aspectos importantes para a aplicação como biocompatibilidade. Foi selecionado um tubo de $\mathrm{CoCr}$ (L605) encruado e com uma quantidade grande de precipitados para os testes, foram selecionadas três faixas de temperatura para o tratamento térmico de recozimento uma abaixo do ponto de solubilização $\left(1000^{\circ} \mathrm{C}\right)$, uma dentro da temperatura $\left(1175^{\circ} \mathrm{C}\right)$ e uma terceira, mais próxima do ponto de fusão alcançável pelo forno $\left(1250^{\circ} \mathrm{C}\right)$. Em cada temperatura foram usados quatro períodos de exposição ao forno( 4, 7, 10 e 15 minutos) totalizando uma matriz com 12 condições de tratamento térmico. Em cada tratamento térmico foram incluídas amostras para ensaio de tração e metalografia. O objetivo deste trabalho é estudar os efeitos dos tratamentos térmicos no comportamento mecânico e na microestrutura do material afim de levantar critérios para determinar os melhores parâmetros de tratamento térmico para a aplicação.
\end{abstract}




\title{
MICROSTRUCTURAL AND MECHANICAL CHARACTERIZATION OF A CO-CR ALLOY. AN EVALUATION OF ITS MECHANICAL PERFORMANCE IN A PRODUCT OF ENGINEERING
}

\author{
Diógenes Cordeiro de Souza Neto
}

\begin{abstract}
This study was developed at IPEN - Institute of Energy and Nuclear Research more specifically in CCTM - Materials Cience and Tecnology Center, with support of Innovatech Medical. It was studied Co-Cr (L605) tubes used for manufacture of coronary stents, this application require a specific mechanical behavior and biocompatibility. The tubes $\mathrm{CoCr}$ (L605) can be acquired in two conditions of thermal history: Cold worked or annealed. If the annealed tube doesn't have the conditions for the application it is hardly possible to reach them with a new heat treatment. Hardened tube opens up more possibilities to adjust the conditions of thermal treatment and obtain the optimum condition of mechanical behavior without compromising other aspects important for application as biocompatibility. A tube CoCr (L605) Hardened and a relatively large amount of precipitates were selected for the tests, three temperature tracks have been selected for the thermal annealing treatment: below the temperature of solution aneealing $\left(1000^{\circ} \mathrm{C}\right)$, at solution aneealing $\left(1175^{\circ} \mathrm{C}\right)$ and a third temperature closest achievable by furnace $\left(1250^{\circ}\right.$ C). For each temperature four periods of exposure where selected $(4,7,10$ and 15 minutes) totaling a matrix of 12 heat treatment conditions. In each heat treatment, samples for tensile testing and metallography were included. The objective of this work is to study the effects of heat treatment on mechanical behavior and microstructure of the material in order to raise criteria to determine the best heat treatment for the application.
\end{abstract}




\section{SUMÁRIO}

Página

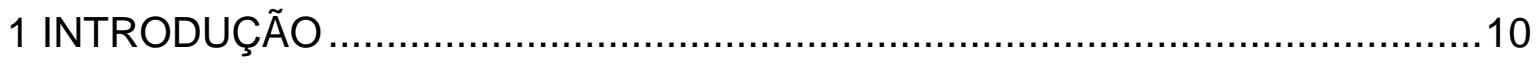

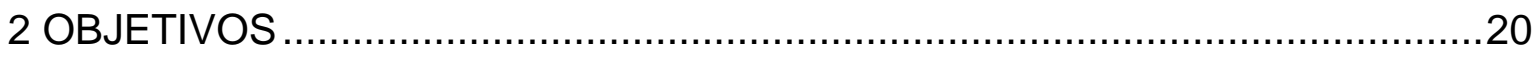

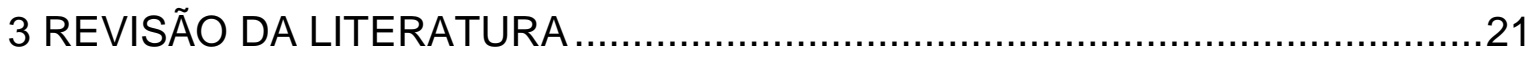

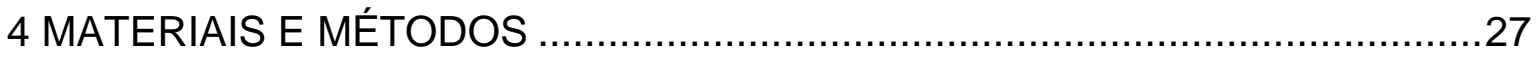

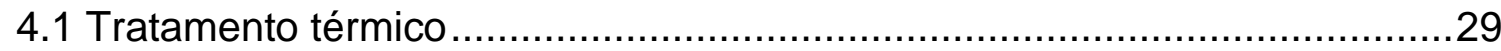

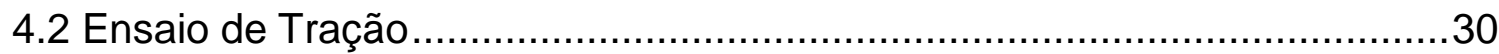

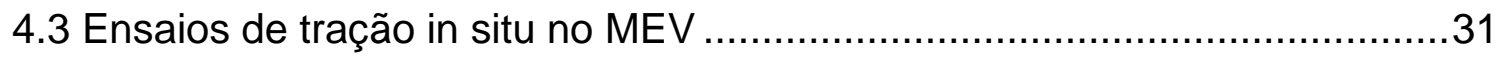

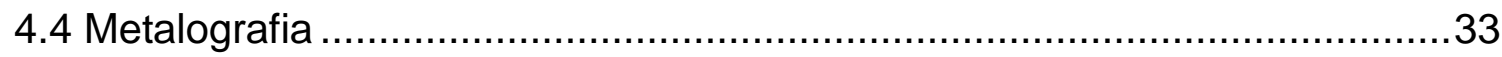

4.5 Microscopia Eletrônica de varredura......................................................36

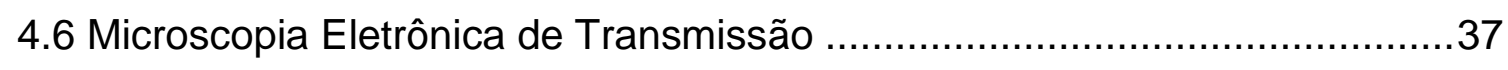

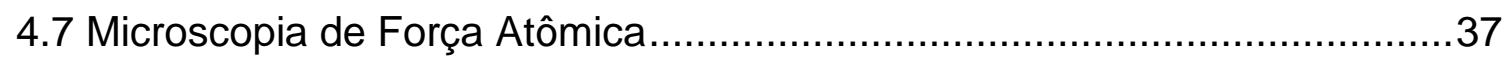

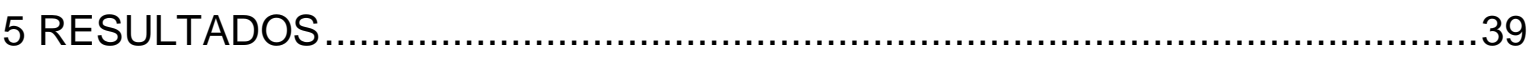

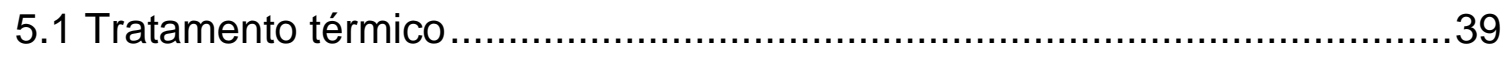

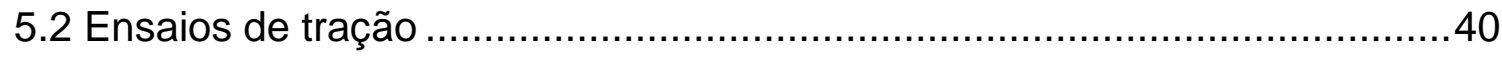

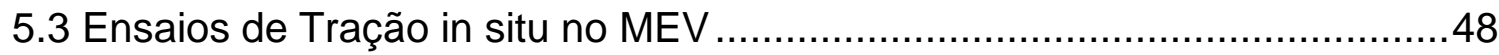

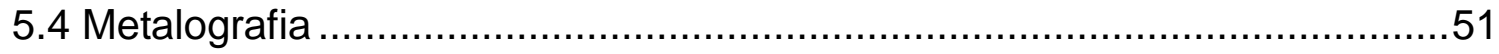

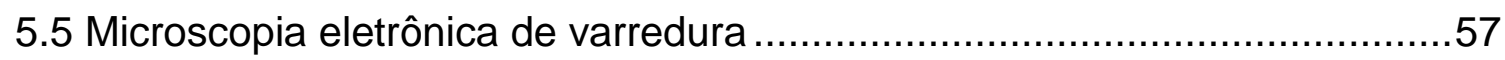

5.6 Microscopia eletrônica de transmissão (MET) ……….................................60

5.7 Microscopia de Força Atômica ....................................................................61

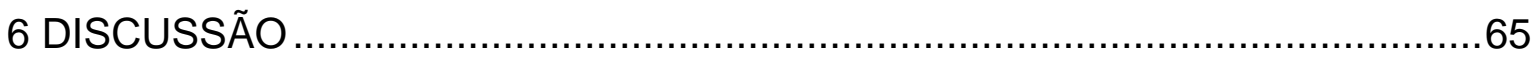

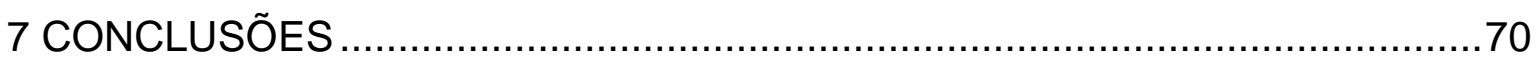

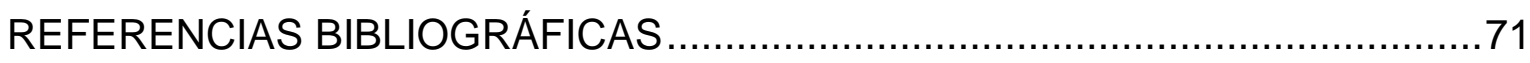




\section{Lista de Tabelas}

Tabela 1 - Formulação utilizada para a decapagem ácida ...............................16

Tabela 2 - Vários precipitados identificados na superliga L605 .........................21

Tabela 3 - Composição Química da Liga L605, segundo ASTM-F90 ...................27

Tabela 4 - Composição Química fornecida pelo fabricante...............................27

Tabela 5 - Dados de ensaio de tração fornecidos pelo fabricante .......................28

Tabela 6 - composição da solução utilizada para o ataque eletrolítico das

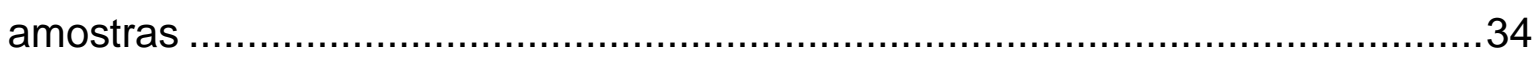

Tabela 7 - Resultados dos ensaios de tração ..............................................47 


\section{Lista de Figuras}

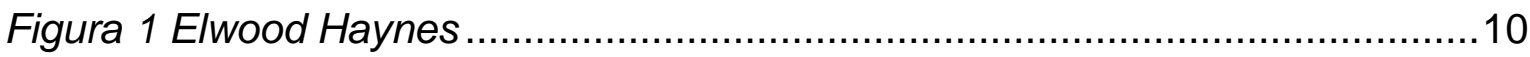

Figura 2 Exemplo de aplicação de um stent ...................................................13

Figura 3 Fluxograma de etapas da fabricação de stents .......................................14

Figura 4 - Projeto digitalizado do sistema de corte, em cinza o laser, em bege o sistema CNC e em vermelho a base de granito juntamente com o suporte do laser também em granito.

Figura 5 Compensação dimensional efetuada na programação do corte a laser .16 Figura 6 - Sistema de corte a laser: Detalhe do sistema laser na parte superior e 0 CNC na parte inferior.

Figura 7 - Forno para tratamento térmico dos stents produzidos e que passam por nova decapagem antes de serem eletropolidos.

Figura 8 - 1 Detalhe do dispositivo que posiciona o stent para o eletropolimento. 2.

Detalhe do Stent posicionado no suporte

Figura 9 - Sistema para eletropolimento de stents.

Figura 10 - Curva típica de Tensão x Corrente para um sistema de eletropolimento.

Figura 11 - Equipamento para crimpagem de stents,

Figura 12- Diagrama ternário Co-Cr-W a $700^{\circ} \mathrm{C}$ .22

Figura 13 - Diagrama ternário Co-Cr-W a $1350^{\circ} \mathrm{C}^{19}$

Figura 14 - Parte de desenho planificado de stent, observa-se que as espessuras das estruturas são inferiores a $100 \mu \mathrm{m}$. .25

Figura 15 - Metalografia em Stent Cortado e tratado termicamente. Observa-se que as dimensões dos grãos são próximos das dimensões do stent .26

Figura 16 - Imagem metalográfica fornecida pelo fabricante .28

Figura 17 - Desenho esquemático do forno de tratamento térmico .29

Figura 18 - Detalhes do forno de tratamento térmico. .30

Figura 19 - Imagem do dispositivo de ensaio montado. 30

Figura 20 - Equipamento de tração in situ do Instituto de criminalística de São Paulo. 32

Figura 21 - Desenho da amostra embutida. .33

Figura 22 - esquerda montagem utilizada para o embutimento das amostras......33

Figura 23 - Montagem utilizada para o ataque eletrolítico das amostras. 
Figura 24 - Padrão de testes para contagem de intercepts sugerido pela norma ASTM E-112.

Figura 25 - Microscópio de varredura por sonda, presente no laboratório de filmes finos .38

Figura 26 - Calibração do forno nas temperaturas trabalhadas. 39

Figura 27 - Leitura do termopar de registro durante o tratamento térmico. 40

Figura 28 - Resultado de ensaio de tração da liga de CoCr L605 como recebido 42 Figura 29 - Gráfico das amostras tratadas a $1000^{\circ} \mathrm{C}$ por $4,7,10$ e 15 minutos .....43 Figura 30 - Gráfico das amostras tratadas a $1175^{\circ} \mathrm{C}$ por $4,7,10$ e 15 minutos .....44 Figura 31 - Gráfico das amostras tratadas a $1250^{\circ} \mathrm{C}$ por 4,7,10 e 15 minutos .45 Figura 32 - Amostra tratada a $1250^{\circ} \mathrm{C}$ por 4 minutos e resfriada rapidamente (têmpera)

Figura 33 - Amostra tratada a $1250^{\circ} \mathrm{C}$ por 4 minutos e envelhecida a $850^{\circ} \mathrm{C}$ por 60 minutos 46

Figura 34 - Coeficientes de encruamento do material após tratamento térmico ...48 Figura 35 - $A$ amostra tratada a $1175^{\circ} \mathrm{C}$ por 7 minutos apresentou Limite de escoamento: de 362MPa e módulo de elasticidade de 793,21 GPa. 49 Figura 36 - A amostra tratada a $1250^{\circ} \mathrm{C}$ por 15 minutos apresentou Limite de escoamento: de 349MPa e módulo de elasticidade de 780GPa.

Figura 37 - Imagem de amostra tratada à $1250^{\circ} \mathrm{C}$ por 15 minutos apos ensaio de tração in situ. .50

Figura 38 - Imagem de amostra tratada à $1250^{\circ} \mathrm{C}$ por 15 minutos apos ensaio de tração in situ. .50

Figura 39 - Metalografia CoCr tratado a $1000^{\circ} \mathrm{C}$ por 4 minutos. .51

Figura 40 - Metalografia CoCr tratado a $1000^{\circ} \mathrm{C}$ por 7 minutos. .52

Figura 41 - Metalografia CoCr tratado a $1000^{\circ} \mathrm{C}$ por 10 minutos. .52

Figura 42 - Metalografia CoCr tratado a $1000^{\circ} \mathrm{C}$ por 15 minutos. .53

Figura 43 - Metalografia CoCr tratado a $1175^{\circ} \mathrm{C}$ por 4 minutos. .53

Figura 44- Metalografia CoCr tratado a $1175^{\circ} \mathrm{C}$ por 7 minutos. .54

Figura 45 - Metalografia CoCr tratado a $1175^{\circ} \mathrm{C}$ por 10 minutos .54

Figura 46 - Metalografia CoCr tratado a $1175^{\circ} \mathrm{C}$ por 15 minutos .55

Figura 47 - Metalografia CoCr tratado a $1250^{\circ} \mathrm{C}$ por 4 minutos .55

Figura 48 - Metalografia CoCr tratado a $1250^{\circ} \mathrm{C}$ por 7 minutos. .56

Figura 49 - Metalografia CoCr tratado a $1250^{\circ} \mathrm{C}$ por 10 minutos .56 
Figura 50 - Metalografia CoCr tratado a $1250^{\circ} \mathrm{C}$ por 15 minutos. .57

Figura 51- Imagem de amostra de CoCr L605 com precipitados........................58

Figura 52 - EDX medido na parte cinza da imagem da figura 40 .......................59

Figura 53 - EDX medido em um precipitado (ponto branco) da figura 40 .59

Figura 54 - Liga de CoCR L605 analisado no microscópio eletrônico de transmissão .60

Figura 55 Liga de CoCR L605 microscopia eletrônica de transmissão. 61

Figura 56 Imagem em perspectiva 3d de microscopia de força atômica 62

Figura 57 imagem em corte de microscopia de força atômica. .63

Figura 58 Imagem em perspectiva $3 d$ de microscopia de força elétrica 63

Figura 59 imagem em corte de microscopia de força elétrica. .64

Figura 60 - Comparação entre resultados de tensão máxima 67

Figura 61 - Comparação entre limites de escoamento .67 


\section{INTRODUÇÃO}

Historicamente muitas das ligas comerciais a base de cobalto são derivadas dos sistemas ternários tungstênio-cobalto-cromo e cobalto-cromomolibdênio investigado inicialmente por Elwood Haynes (Figura 1).

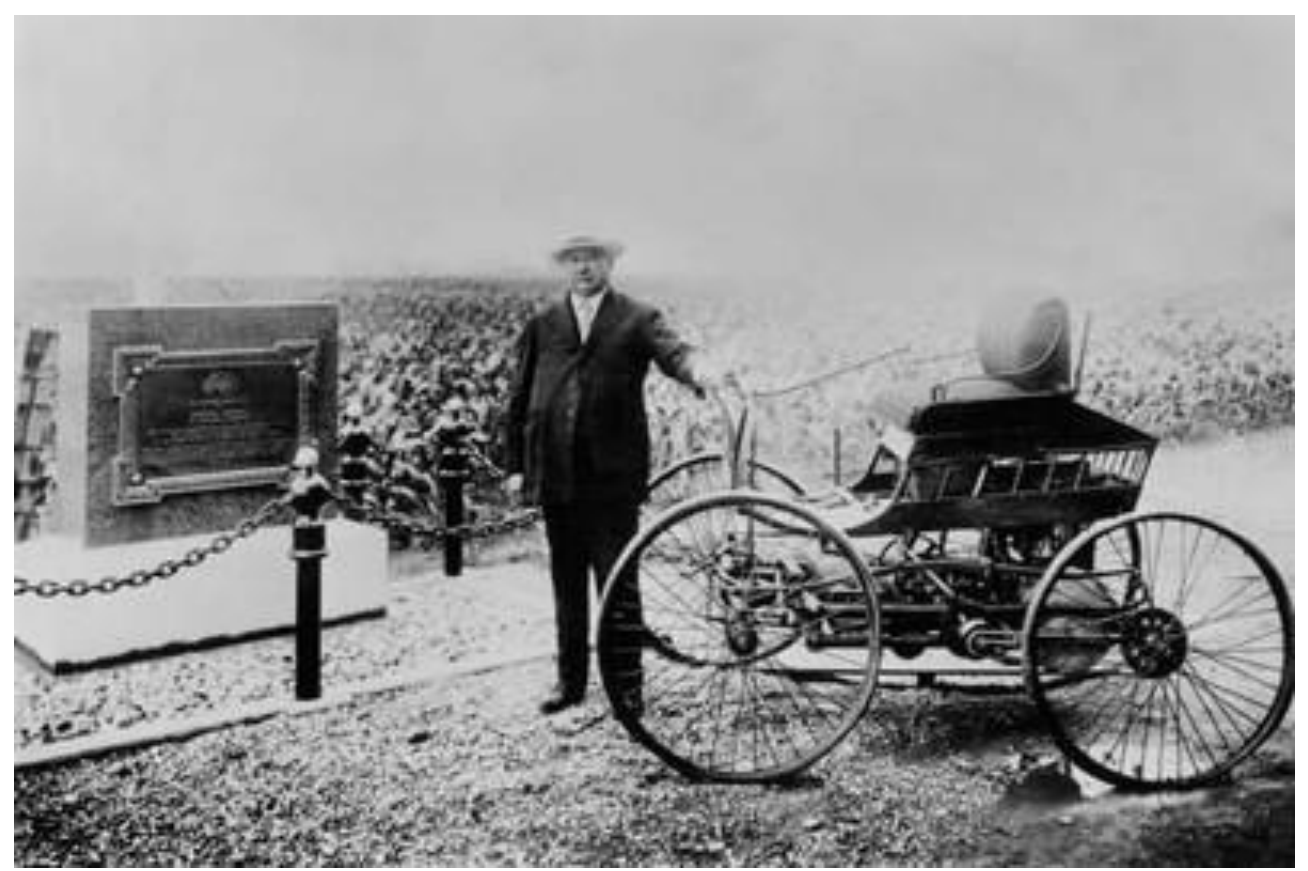

Figura 1 Elwood Haynes ${ }^{1}$

No início do século 20, ele descobriu a alta resistência mecânica e a natureza inoxidável da liga binária de cobalto-cromo, e mais tarde identificou o tungstênio e o molibdênio como componentes importantes para melhorar a liga. Quando ele descobriu estas ligas, Haynes as nomeou de Stellite que em latim significa estrela, por causa de seu brilho.

O cobalto é classificado como um metal criticamente estratégico por suas aplicações na indústria de defesa e na dependência de nações industrializadas da importação de cobalto. O cobalto é utilizado na fabricação de superligas resistentes à temperatura elevadas (próximas a $1000^{\circ} \mathrm{C}$ ), à corrosão e ao desgaste. Algumas ligas de cobalto são biocompatíveis, o que permite a fabricação de dispositivos implantáveis. Como grupo, as ligas a base de cobalto podem ser geralmente descritas como resistentes ao desgaste, à corrosão, e ao calor. Muitas das propriedades das ligas surgem da estrutura cristalográfica de cobalto (em particular, a sua resposta ao carregamento mecânico); dos efeitos das soluções sólidas com adições de cromo, tungstênio e molibdênio, da formação de 
carbonetos metálicos, e da resistência à corrosão, estes últimos efeitos auxiliados pelo cromo².

Esse tipo de material é muitas vezes a melhor escolha para ser utilizada em sistemas de alta complexidade técnica,como em partes de turbinas para geração de energia elétrica ${ }^{3}$, turbinas de avião, partes de sistemas de reatores nucleares, enfim diversas aplicações que exigem componentes que mantenham a resistência mecânica mesmo após serem submetidas a temperaturas elevadas ${ }^{4}$. No caso de aplicações como partes de usinas nucleares, pode ser necessário adicionar camadas depositadas para evitar que íons radioativos se desprendam do material por qualquer razão ${ }^{5}$.

Minérios de Cobalto são normalmente encontrados em associações secundárias com diversos minerais ricos em cobre, níquel e prata. Alguns dos principais minerais são: arsenetos sulfetos e óxidos. A concentração de cobalto nestes minerais é geralmente menor que $0,5 \%$ da massa o que faz necessário que o eventual produtor de cobalto, desenvolva métodos únicos para concentração e refino ${ }^{6}$.

O papel de materiais no campo da saúde como o desenvolvimento dos biomateriais é dirigido por produtos que possam aumentar e/ou manter a qualidade de vida ao mesmo tempo em que diminuem o custo do atendimento médico, reduzindo complicações, e fazendo com que sejam necessários menos tempo de estadia em hospitais, mantendo ainda assim alto desempenho ${ }^{7}$.

A liga de Cobalto-Cromo que é o objeto do presente trabalho, é comumente usada para implantes médicos, por causa da sua alta resistência mecânica, alta resistência à corrosão ou estabilidade química e comportamento não magnético que resultam em biocompatibilidade ${ }^{a}$, no entanto o único aspecto que põe em xeque a biocompatibilidade é a presença de precipitados dependendo da história térmica do material ${ }^{8}$. As aplicações no ramo da medicina incluem a próteses de quadril, joelhos, cotovelos, ombros, tornozelos ${ }^{9}$, válvulas do coração, implantes coronários e além da utilização para implantes odontológicos.

\footnotetext{
a Biocompatibilidade - É a capacidade de um material desempenhar uma resposta apropriada numa determinada aplicação com o mínimo de reações alérgicas, inflamatórias ou toxicas, quando em conato com tecidos vivos ou fluidos orgânicos, isto é, existe uma interação entre tecidos humanos e fluidos com o implante ou material
} 
As doenças cardiovasculares constituem a principal causa de mortalidade e morbidade no Brasil e no mundo. Segundo dados da Organização Mundial da Saúde, em 2002, no mundo, do total de 16,7 milhões de óbitos, 7,2 milhões ocorreram por doença arterial coronariana. Estima-se, para 2020, que esse número possa se elevar os valores entre 35 e 40 milhões. No Brasil, em 2005, houve 196.474 internações e 84.945 óbitos registrados no Sistema de Informação de Mortalidade por doença arterial coronariana ${ }^{10}$.

Hoje em dia, já existem mais de 1 milhão de pessoas com stents implantados em suas artérias coronarianas, para conter os efeitos da arterosclerose $^{\mathrm{b}}$, sendo que a maioria que é implantada hoje, é fabricada a partir de uma liga de cobalto e cromo chamada Co-Cr (L605); portanto, o conhecimento prévio do comportamento desse material sob os mais diversos aspectos é fundamental, pois a maioria dos implantes são avaliados com base na sobrevivência do indivíduo; questões como resistência à fadiga, devem ser bem conhecidas.

A liga possui boas características para deformação e soldagem. Pode ser trabalhada a frio ou forjada a quente, permitindo que a temperatura seja mantida a $1205^{\circ} \mathrm{C}$ durante um tempo suficiente para aquecer toda a peça. Quando trabalhada a frio, esta pode endurecer rapidamente de forma que para componentes complexos é preciso alternar operações de deformação com tratamentos térmicos de recozimento.

A liga forjada é normalmente tratada termicamente entre $1175^{\circ} \mathrm{C} \mathrm{e}$ $1230^{\circ} \mathrm{C}$ e rapidamente esfriada mergulhando em agua para propriedades ótimas. Possui elevada resistência mecânica em temperaturas altas, mas a exposição por períodos prolongados ou se atingir a temperatura de "solution annealling" (recozimento próximo à temperatura de fusão) pode ter suas propriedades mecânicas e microestruturais alteradas.

As ligas atuais a base de cobalto estão um tanto mudadas desde aquelas primeiras usadas por Haynes. As diferenças mais importantes são o controle de carbono e silício (que eram considerados impurezas nas primeiras ligas). De fato, há grande diferença nas concentrações de carbono e tungstênio, o que influencia a quantidade e o tipo de carboneto que ocorre na microestrutura durante a

${ }^{\mathrm{b}}$ Arterosclerose ou arteriosclerose (sinônimos)- Doença causada pelo acumulo de gordura nas paredes das artérias causando diminuição da passagem do sangue ou o entupimento da mesma. 
solidificação. A velocidade de resfriamento e pequenas mudanças na composição, como adição de molibdênio ${ }^{11}$, têm grande influência na formação dos carbonetos que em geral são do tipo $\mathrm{M}_{6} \mathrm{C}$ e $\mathrm{M}_{23} \mathrm{C}_{6}$ mas outros tipos podem ser encontrados ${ }^{12}$.

Convencionalmente admite-se que as estruturas do stent devam ter ao menos alguns grãos na seção transversal para prevenir que não ocorram falhas prematuras no stent ${ }^{13}$, isso significa que para estruturas da ordem de $100 \mu \mathrm{m}$ o tamanho de grão não pode ser maior do que ASTM 5 (três grãos por secção).

Para a aplicação no corpo humano, a resistência à corrosão é a característica de maior importância para avaliar a biocompatibilidade. A liga de CoCr L605, possui características inoxidáveis superiores aos aços inoxidáveis usados para implantes ${ }^{14}$.

Uma razão para a falha de um stent é a possibilidade da superfície do stent liberar íons metálicos, que em muitos casos são gatilhos para a reestenose, esta possibilidade é muito remota no caso de ligas de Co-Cr, pois são quimicamente estáveis.

Na medicina, um stent é uma estrutura metálica que inserido em uma veia ou artéria corpo serve para tratar de doenças oclusivas, este funciona juntamente com um balão inflável de angioplastia que serve para empurrar as paredes das artérias desobstruindo a mesma deixando no local o stent este que tem a função de impedir que as paredes da artéria colapsem obstruindo novamente o fluxo (Figura 2).

Stent com balão de angioplastia

1.

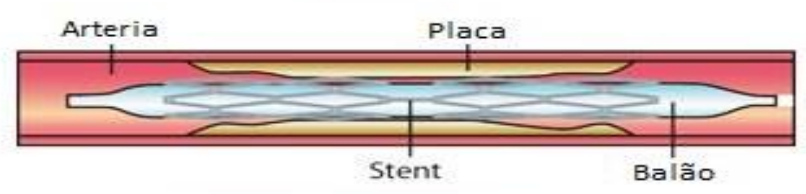

2.

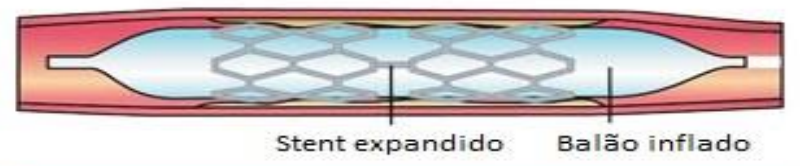

3.

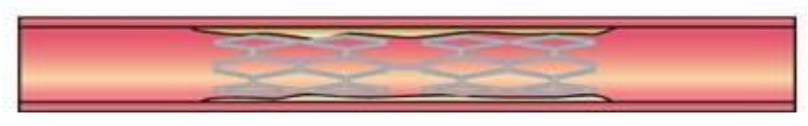

Figura 2 Exemplo de aplicação de um stent ${ }^{15}$

O uso de stents (prótese endovascular) associados à angioplastia coronariana reduz a ocorrência de eventos adversos, reestenose angiográfica e 
reoclusão, em comparação à angioplastia convencional e vêm substituindo gradualmente as cirurgias de revascularização.

A angioplastia é um procedimento não cirúrgico, não restrito à área coronária, que desobstrui artérias ou vasos por meio de um cateter e introduz uma prótese para manter o diâmetro original do vaso/artéria. No Brasil são realizadas anualmente 90000 angioplastias contra 30000 cirurgias de revascularização, sendo que a maioria dos procedimentos de angioplastia inclui a colocação de um ou mais stents $^{16}$.

A Sociedade Brasileira de Hemodinamica e Cardiologia Intervencionista (SBCHI) estima que sejam implantados no Brasil 60 mil stents por ano. Cabe ainda destacar que o mercado de stents é dominado por um número reduzido de grandes empresas.

O processo de fabricação do stent (Figura 3) não varia muito conforme o material envolvido, ou seja, o processo utilizado para a fabricação de stents de CoCr por exemplo é muito parecido com o processo de fabricação de stents de aço inox 316L, sendo que os pontos que variam de fato são o tratamento térmico e as soluções utilizadas nos tratamentos químicos.

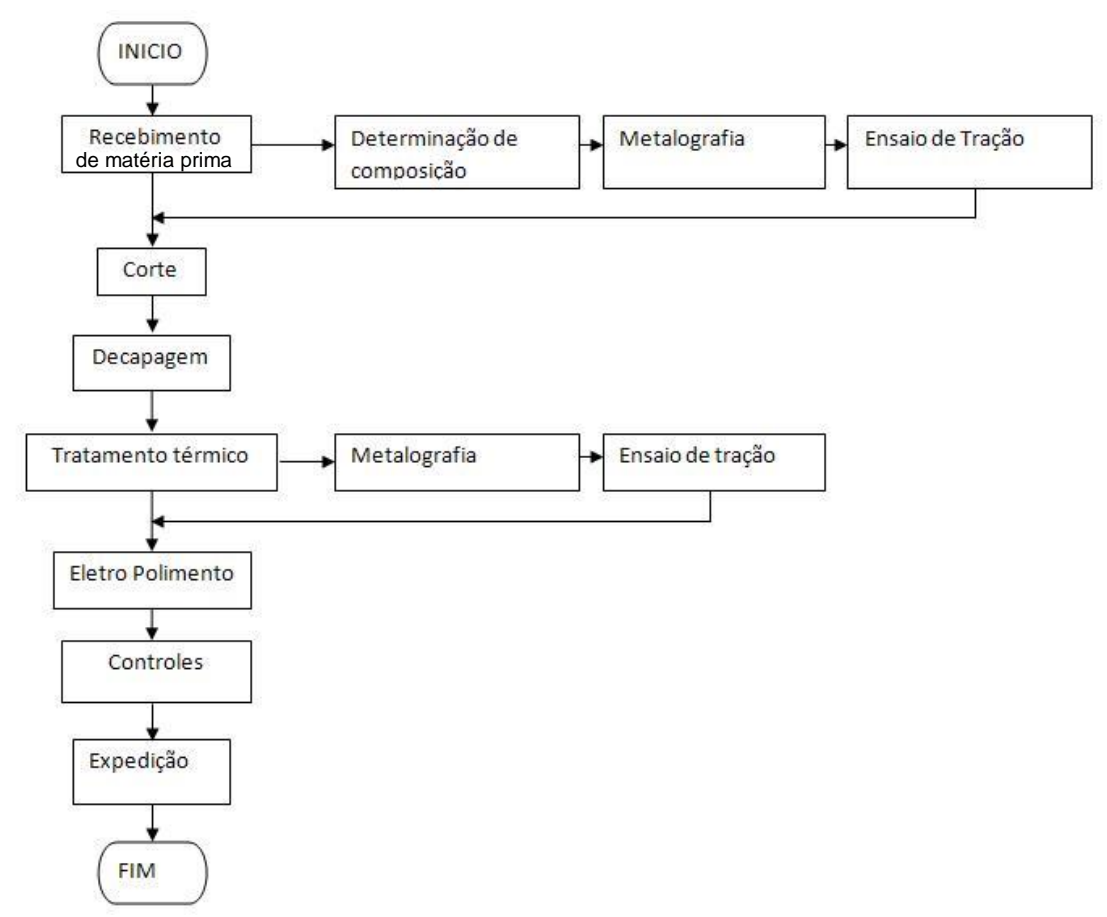

Figura 3 Fluxograma de etapas da fabricação de stents

A primeira etapa da fabricação do stent, é a compra do material, este deve estar dentro dos requisitos de projeto do stent, atendendo com precisão 
características como: Composição química, diâmetro externo, diâmetro interno e suas tolerâncias, ausência de defeitos.

O sistema de corte de stents foi projetado exclusivamente para este fim, de forma que é capaz de cortar apenas tubos. O laser é um laser pulsado fabricado pela Lasag modelo KLS246FC, este laser é específico para cortes precisos em espessuras finas. O sistema CNC é de fabricação Aerotech modelo Vasculathe ACS, que consegue executar comandos numéricos em $X$ (linear) e $\Theta$ (rotativo) fornecendo precisão de reposicionamento na ordem de $2 \mu \mathrm{m}$ (Figura 4).

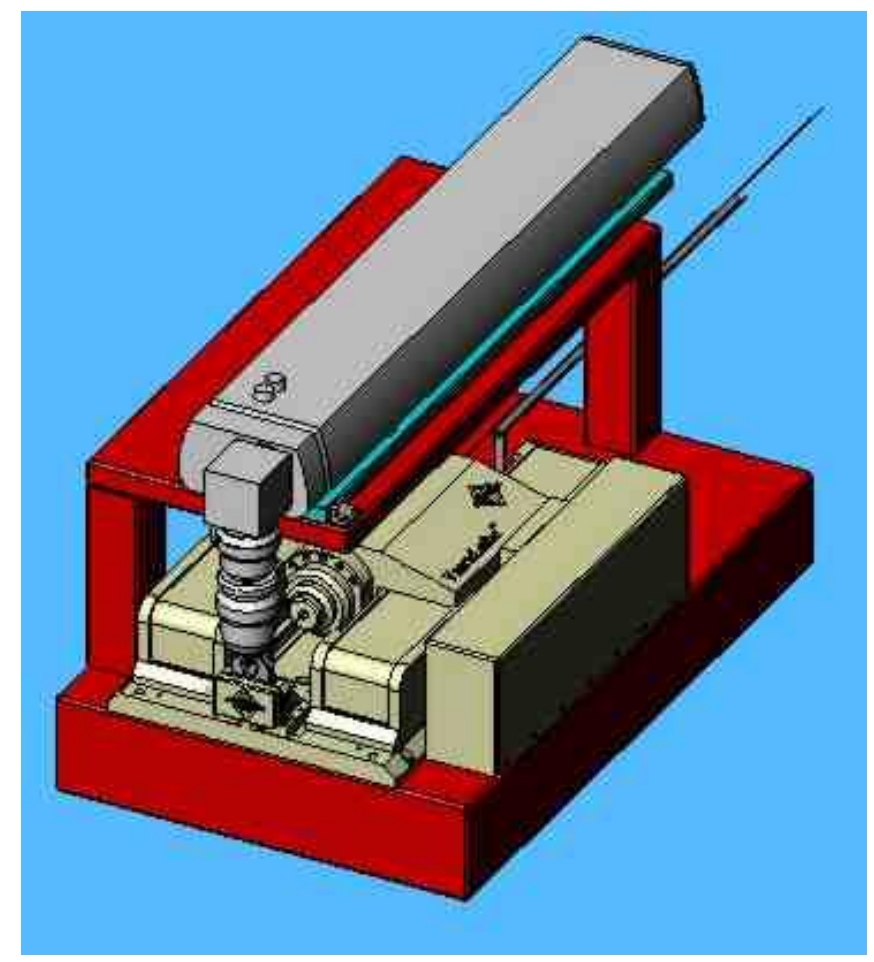

Figura 4 - Projeto digitalizado do sistema de corte, em cinza o laser, em bege o sistema CNC e em vermelho a base de granito juntamente com o suporte do laser também em granito.

A segunda etapa, é o corte a laser que segue um desenho oriundo do projeto planificado do Stent. Tendo em vista o material que será retirado posteriormente ao corte nos processos de decapagem e eletropolimento, faz-se uma compensação (Figura 5) nas dimensões afim de atingir as dimensões de projeto ao fim do processo. Assim efetua-se o corte a laser, o equipamento a laser normalmente utilizado é um laser do tipo Nd:YAG, combinado com um sistema CNC de corte nas direções $X$ e $\Theta$ (Figura 6 ) e um gás de assistência para o corte que no caso utiliza-se oxigênio(para outros materiais como Nitinol, opta-se pro argônio como gás de assistência). 


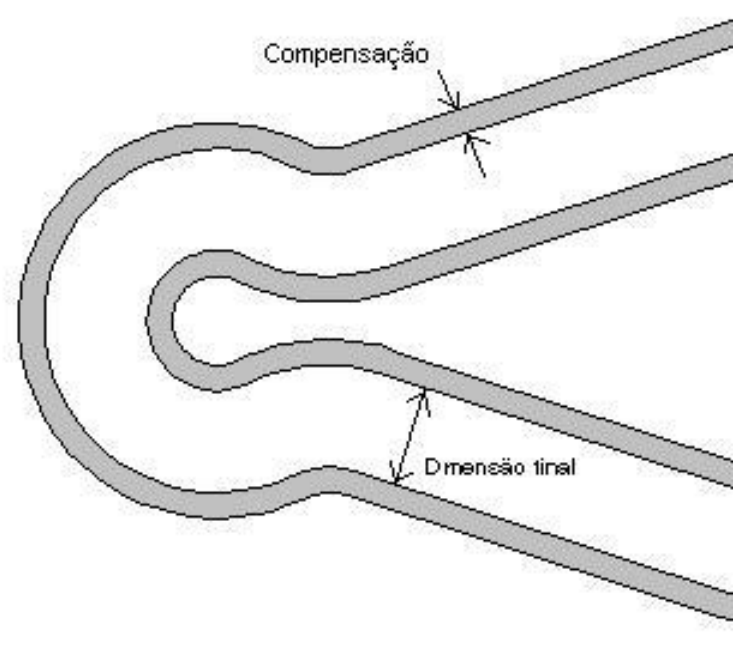

Figura 5 Compensação dimensional efetuada na programação do corte a laser

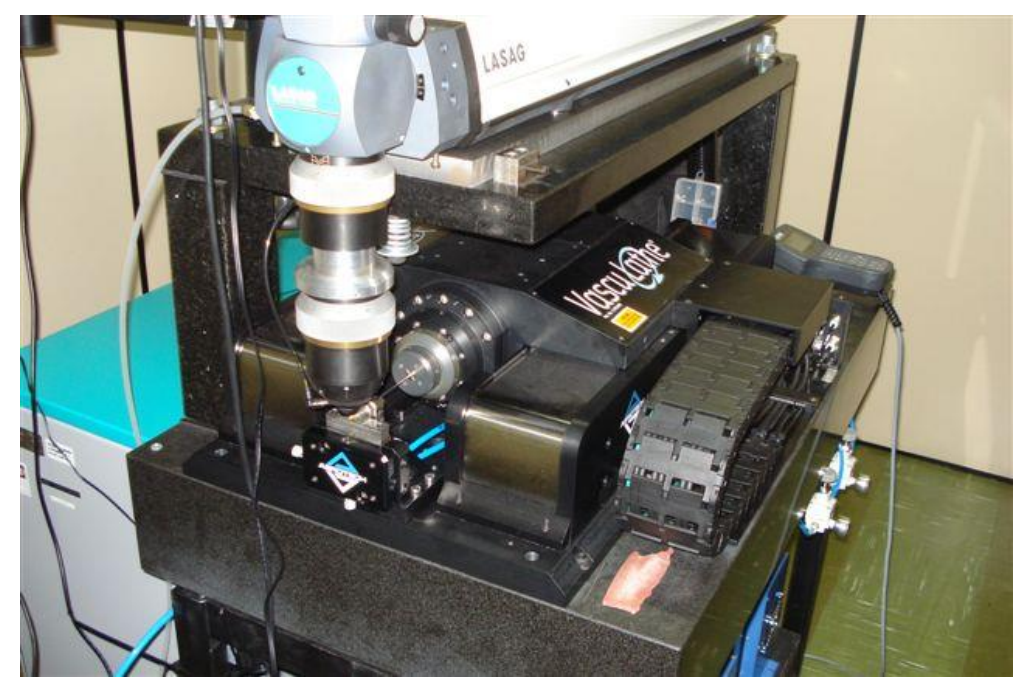

Figura 6 - Sistema de corte a laser: Detalhe do sistema laser na parte superior e o CNC na parte inferior.

Na etapa seguinte da fabricação, o stent é decapado em uma solução ácida(Tabela 1) afim de deixar o material do stent completamente exposto ou seja, sem nenhuma sujeira ou óximo em sua superfície.

Tabela 1 - Formulação utilizada para a decapagem ácida

\begin{tabular}{cc} 
Reagente & Concentração \\
\hline Ácido Fluorídrico $(\mathrm{HF})$ & $10 \%$ \\
Ácido Nítrico $\left(\mathrm{HNO}_{3}\right)$ & $60 \%$ \\
Água Deionizada $\left(\mathrm{H}_{2} \mathrm{O}\right)$ & $30 \%$
\end{tabular}


Após decapados os stents passam elo tratamento térmico(Figura 7), este tratamento é a vácuo para que não haja formação de óxidos na superfície. Um termopar inserido dentro da câmara de vácuo juntamente com os stents controla a temperatura do processo.

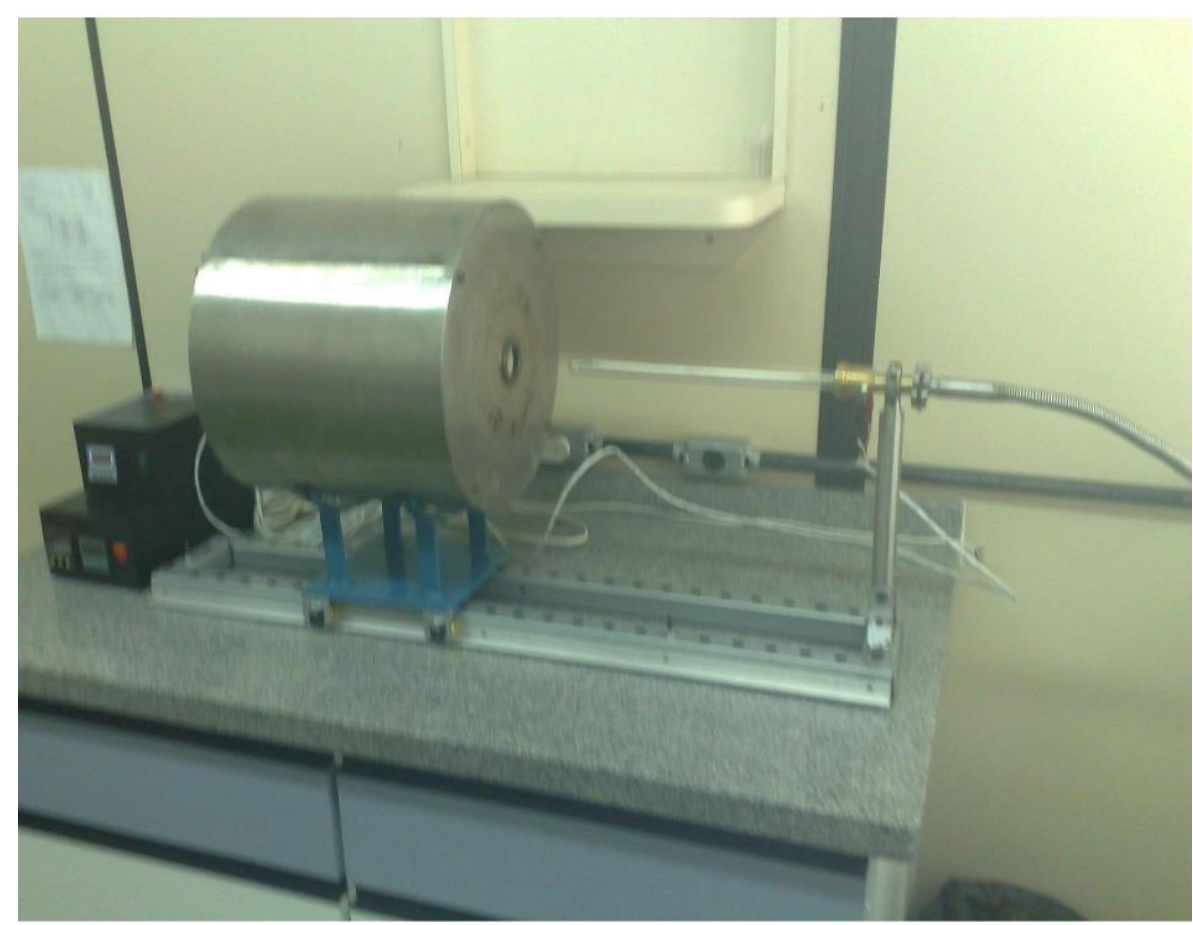

Figura 7 - Forno para tratamento térmico dos stents produzidos e que passam por nova decapagem antes de serem eletropolidos.

O eletropolimento é o processo mais crítico da fabricação, que consiste em uma retirada eletrolítica de material do stent de forma que este fique com a superfície completamente lisa. A maior dificuldade neste processo, é manter todas as estruturas do stent homogêneas.

Para o procedimento é utilizada uma cuba com solução de eletropolimento, um sistema de aquecimento para a solução, eletrodos(Figura 8) e uma fonte DC para aplicar tensão entre o Stent e os eletrodos dentro da cuba.

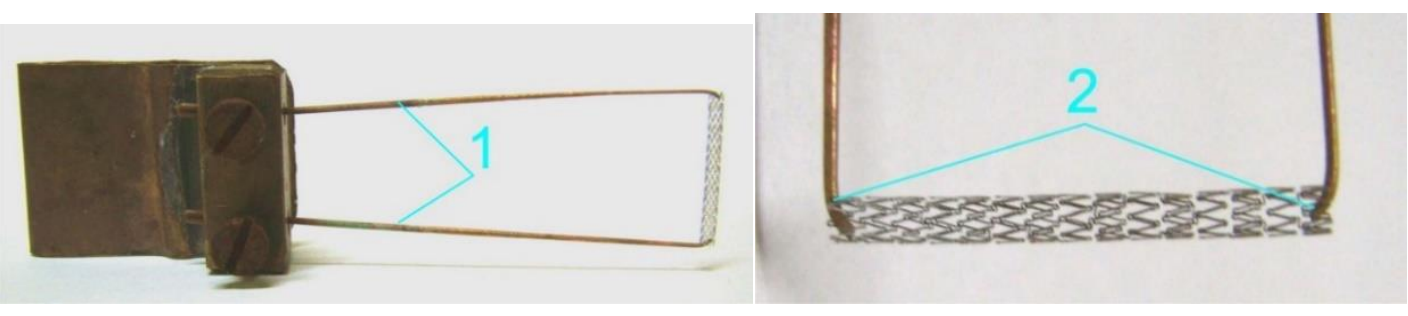

Figura 8 - 1 Detalhe do dispositivo que posiciona o stent para o eletropolimento. 2. Detalhe do Stent posicionado no suporte 
O eletropolimento (Figura 9) consiste de polarizar anodicamente o stent, em uma célula eletrolítica específica para este fim, e está baseado em dois princípios: (a) brilho anódico: supressão do efeito da microestrutura na taxa de dissolução; (b) nivelamento anódico: diferença na taxa de dissolução entre picos e vales.

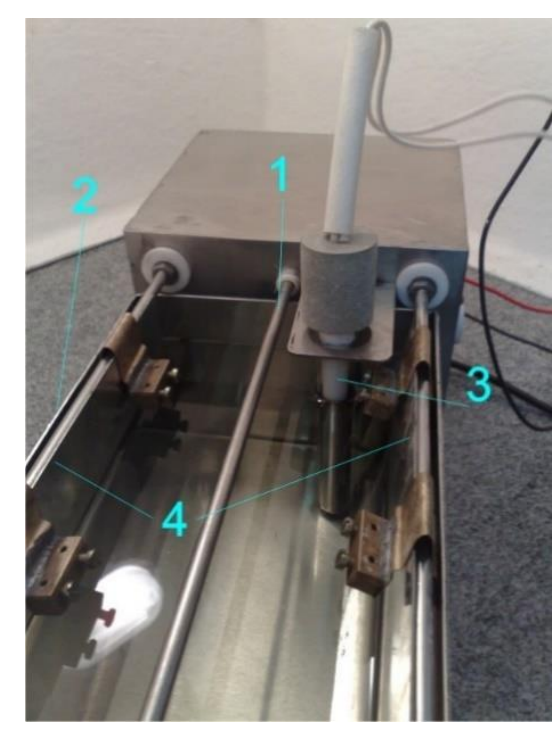

1. "Gancheira" na qual os stents ficam imersos horizontalmente na solução

2. Cuba de inox com capacidade para 4 litros de solução

3. Um aquecedor inserido na solução para aumento de temperatura.

4. Dois eletrodos inseridos na cuba.

Figura 9 - Sistema para eletropolimento de stents.

Ao aplicar a tensão elétrica entre o stent e o eletrodo dentro da célula contendo o eletrólito, forma-se um filme na superfície do material; este filme deposita-se preferencialmente nos vales (Figura 10), ao mesmo tempo em que libera íons para a solução com a formação do filme. Nos picos a liberação de íons é mais rápida do que nos vales provocando uma tendência de as superfícies se alinharem. 


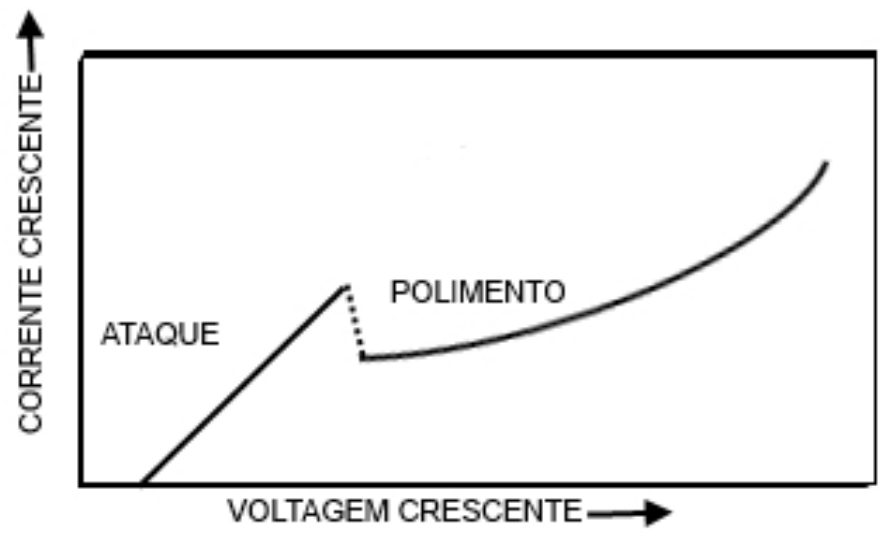

Figura 10 - Curva típica de Tensão x Corrente para um sistema de eletropolimento.

Após o eletropolimento, o stent passa por processos de controle de qualidade, no qual cada stent é analisado afim de detectar não conformidades como espessuras fora da especificação, defeitos ocorridos durante o eletropolimento. Aprovado em todas as etapas, o stent é crimpado(Figura 11) em um balão de angioplastia e esterilizado em uma balaclava.

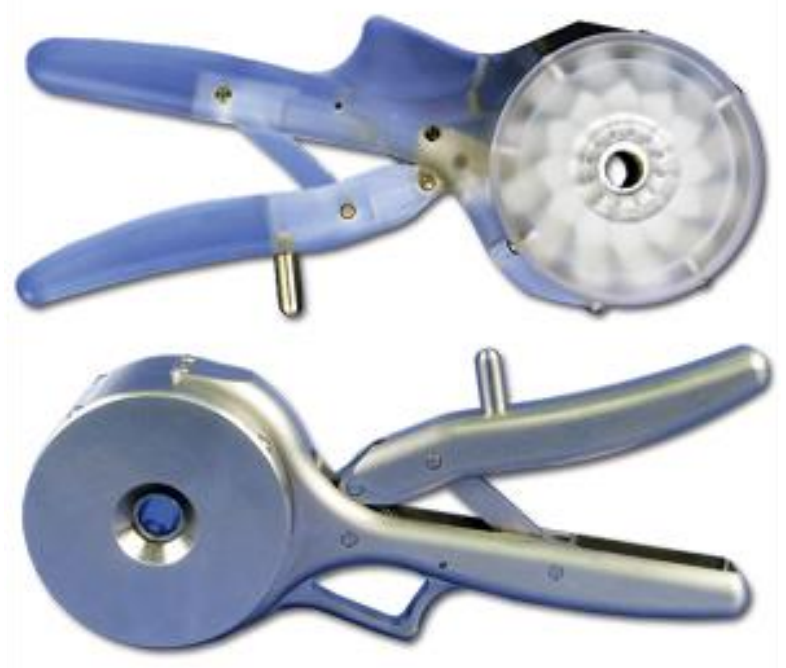

Figura 11 - Equipamento para crimpagem de stents ${ }^{17}$, 


\section{OBJETIVOS}

Este trabalho tem como objetivo caracterizar o comportamento mecânico da super liga de CoCr (L605) além de fatores críticos que influenciam o seu desempenho para aplicação como stent, e dreterminar como o tratamento térmico do material interfere na microestrutura e nas propriedades mecânicas e quais as relações de tempo e temperatura são ideais para alcançar propriedades ótimas. 


\section{REVISÃO DA LITERATURA}

A liga L-605 é uma liga de cobalto-niquel-cromo-tungstênio que combina excelente resistência mecânica em altas temperaturas e boa resistência à oxidação a temperaturas de até $980^{\circ} \mathrm{C}$ por exposições prolongadas comparáveis com outras ligas à base de cobalto, e excelente resistência à oxidação e sulfidação. Esta liga pode ser fabricada e conformada por técnicas convencionais e tem sido usada para fabricação de componentes fundidos. Outra característica interessante é que dificilmente adere a outras superfícies.

Naturalmente, o cobalto possui duas fases estáveis, hexagonal compacto até $417^{\circ} \mathrm{C}$ e cúbico de face centrada em temperaturas acima de $417^{\circ} \mathrm{C}$. A adição de elementos de liga altera a estabilidade termodinâmica em cúbica de face centrada ${ }^{18}$.

A liga L605 geralmente consiste em uma solução sólida supersaturada cúbica de face centrada ( $\mathrm{Co}, \mathrm{Cr}, \mathrm{W}, \mathrm{Ni}, \mathrm{C}$ ) com carbonetos primários dispersos(Tabela 2). Os carbonetos que aparecem durante a solidificação do lingote são chamados carbonetos primários. A sua natureza, forma, tamanho e distribuição na matriz dependem da composição química da liga (tanto macro e micro), e da taxa de resfriamento após a solidificação.

Tabela 2 - Vários precipitados identificados na superliga $L 605^{19}$

Componentes

\begin{tabular}{cc}
\hline Carbonetos & $\mathrm{M}_{7} \mathrm{C}_{3}$ \\
& $\mathrm{M}_{23} \mathrm{C}_{6}$ \\
& $\mathrm{M}_{6} \mathrm{C}$ \\
\hline \multirow{3}{*}{ Componentes Intermetálicos } & $\mathrm{Co}_{3} \mathrm{~W}$ \\
& $\mathrm{Co}_{3} \mathrm{~W}(\alpha$ e $\beta)$ \\
$\mathrm{Co}_{7} \mathrm{~W}_{6}$
\end{tabular}

A liga de $\mathrm{Co}-\mathrm{Cr}$ (L-605) (Figuras 12 e 13) compete com outras ligas de materiais metálicos como aço inox 316L e ligas de magnésio bioabsorvíveis (WE43, $\mathrm{AZ31})^{20}$. 


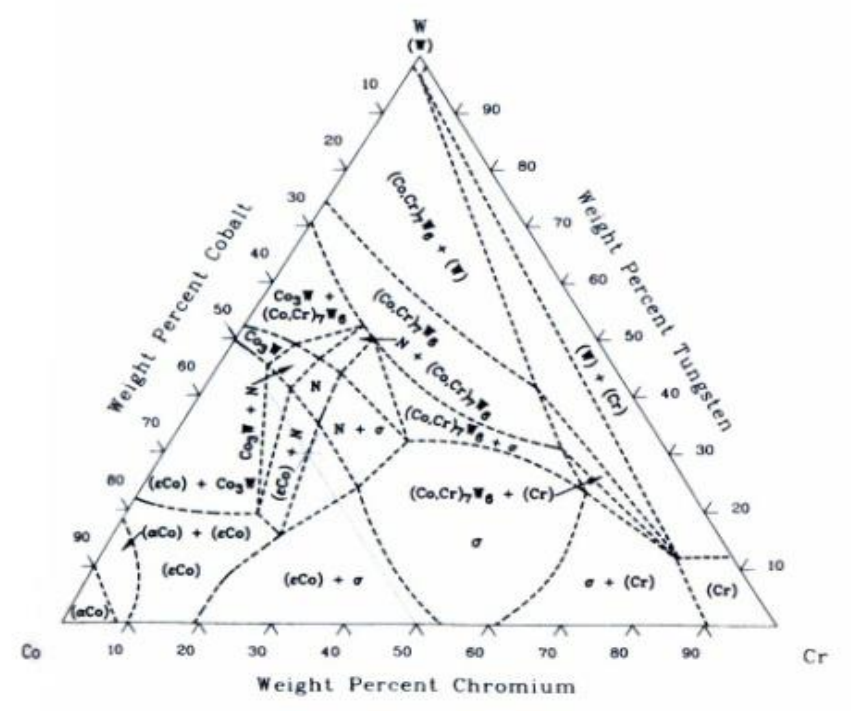

Co-Cr-W isothermal section at $700^{\circ} \mathrm{C}\left(1290^{\circ} \mathrm{F}\right)$

Figura 12- Diagrama ternário Co-Cr-W a $700^{\circ} \mathrm{C}^{21}$

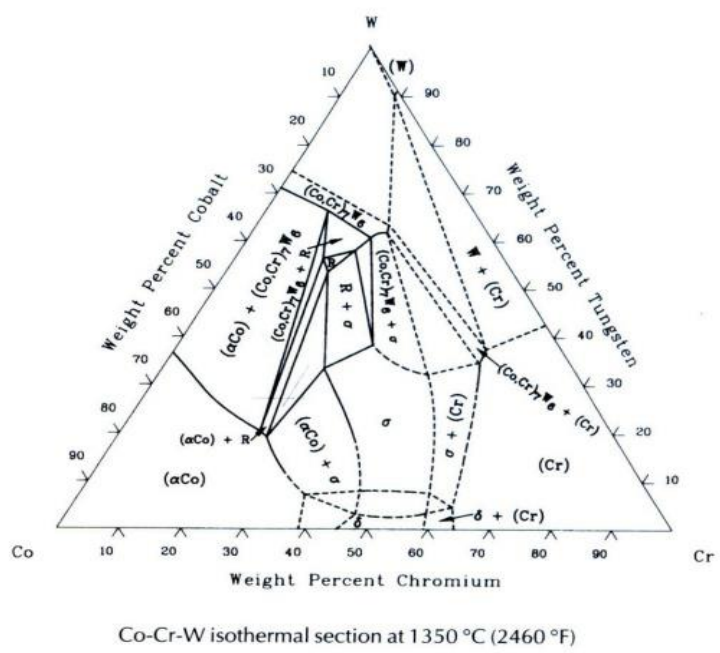

Figura 13 - Diagrama ternário Co-Cr-W a $1350^{\circ} \mathrm{C}^{19}$

De acordo com a norma ASTM F-90 que normaliza a liga, trabalhada a frio ou submetida a tratamento térmico de recozimento, esta deve ter resistência à tração entre $860 \mathrm{MPa}$ e $1250 \mathrm{MPa}$, limite de escoamento entre $310 \mathrm{MPa}$ e $760 \mathrm{MPa}$ e ductilidade entre $15 \%$ e $45 \%$. Portanto, suas propriedades dependem da história térmica.

Tem sido estudado que a dissolução parcial dos carbonetos por recozimento próximo a temperatura de fusão aumentam a ductilidade e a resistência à fadiga da liga à base de cobalto $^{22}$, No entanto, a precipitação de 
carbonetos por envelhecimento(“aging") é o mecanismo mais importante para endurecimento 23 .

Alguns estudos comparam as características mecânicas do implante feito de Co-Cr L605 com implantes feitos com outros materiais à base de ferro como inox (316L), ligas de titânio e nitinol. Nenhum material biocompatível combina melhor as características mecânicas do que o CoCr L605 para a aplicação em stents. Esta afirmação se deve a ponderações sobre o que seria um stent ideal e uma característica almejada é a "força radial" diretamente proporcional ao limite de escoamento.

O fator mais importante para a biocompatibilidade de qualquer material é sua resistência à corrosão ${ }^{24}$, o comportamento quanto à corrosão de um implante é influenciado por vários fatores, incluindo a composição química, a microestrutura e a superfície do material. As ligas de Co-Cr atuais são superiores ao aço inoxidável, tanto em fadiga quanto em resistência ao desgaste e, portanto, são os preferidos em próteses totais, tanto em locais de apoio e em articulações ${ }^{25}$.

O tratamento de doenças arteriais usando stents metálicos foi a das intervenção médica mais revolucionária e que mais rapidamente foi adotada pela medicina em nosso tempo ${ }^{26}$. $O$ implante de stents para o tratamento percutâneo da doença arterosclerótica coronária obstrutiva para prevenir e resolver oclusões agudas do vaso alvo, aumentou a segurança imediata da intervenção coronária percutânea enquanto no médio prazo mostrou-se irrefutavelmente superior a outras técnicas em reduzir as taxas de reestenose 27,28

A maior aceitação do uso dos stents como modalidade primária para o tratamento percutâneo da doença aterosclerótica coronária ampliou suas aplicações para lesões de maior complexidade. Associado ao crescimento tecnológico promoveu resposta imediata da indústria, levando ao desenvolvimento de uma grande variedade de modelos de stents vasculares, com desenhos e características inovadoras, tornando-se a modalidade dominante de intervenção coronária percutânea em todo o mundo ${ }^{29}$. Em teoria, o stent ideal deveria ${ }^{30}$ :

(1) ser confeccionado com material trombo-resistente e biocompatível;

(2) ter adequada flexibilidade em sua forma não expandida, permitindo a navegação em vasos tortuosos e calcificados; 
(3) ter adequada radiopacidade ${ }^{c}$, que permita visualização fluoroscópica para guiar seu posicionamento preciso e no estado expandido, possibilite sua identificação no vaso coronário facilitando a realização de pós-dilatações e a avaliação de sua perviedade em estudos futuros;

(4) apresentar baixo recolhimento elástico e mínimo encurtamento longitudinal quando expandido, mantendo máxima força radial;

(5) apresentar configuração que forneça cobertura uniforme da circunferência vascular, gerando baixa relação metal/artéria, boa conformidade com as curvas vasculares, assim como perviedade e acesso a ramos secundários;

(6) ter um sistema de entrega flexível e de baixo perfil, de forma a não comprometer a navegabilidade do sistema;

(7) ser firmemente montado sobre o balão de entrega, de forma a não ser deslocado do sistema em seu trajeto até o local de implante;

(8) ser montado sobre balão de entrega que apresente mínimo crescimento longitudinal $(<1 \mathrm{~mm})$ para fora dos limites do stent, que suporte altas pressões de insuflação sem se romper e que seja não complacente o suficiente para promover expansão previsível e adequada do stent;

(9) ter disponibilidade de diâmetros e extensões variados; e

(10) apresentar boa relação custo-benefício.

A espessura das estruturas do Stent tem sido reconhecida como um importante fator para reestenose ${ }^{d}$, ou seja, o uso de um dispositivo mais fino está associado com uma redução significativa da reestenose angiográfica e clínica após a utilização do stent ${ }^{31}$. A habilidade de fazer stents com estruturas ultrafinas com maior resistência é o maior atrativo das ligas à base de cobalto para a medicina ${ }^{32}$.

Um artigo que compara as performances mecânicas de stents fabricados de aço inox, ligas de magnésio e ligas de cobalto chega às seguintes conclusões ${ }^{9}$ :

- Um risco significativamente maior de fratura é previsto em um stent de magnésio com relação ao stent de aço;

\footnotetext{
${ }^{c}$ Radiopacidade - capacidade do material de deter raios $X$ permitindo sua visualização.

${ }^{d}$ Reestenose - Ocorrencia de uma nova obstrução na artéria que já havia sito tratada.
} 
- As estruturas dos stents de magnésio e do stent de aço possuem área transversais várias vezes maiores do que aquelas dos modernos stents de CoCr para desempenho comparável em termos de força radial e recolhimento (recoil);

A sobrevida da pessoa que recebe um implante é a base de cálculo para determinar os critérios de projeto para resistência à fadiga no caso de implantes. Esta é uma aproximação pouco satisfatória com relação à segurança, pois o quão perto se está da falha permanece desconhecido ${ }^{33}$.

Para poder projetar evitando tais falhas por fadiga, os stents são avaliados com base em testes de sobrevivência, ou seja, se for necessária uma vida útil de 100 milhões de ciclos, o que normalmente corresponde a dez anos de um coração batendo. O teste é realizado para avaliar se o stent sobrevive a estes ciclos sob carga acelerada ${ }^{34}$, em um equipamento que simula o batimento do coração de forma não ser necessário dez anos para o teste, mas mesmo assim esta simulação costuma levar alguns meses.

Em situações em que as dimensões transversais (Figura 14) dos dispositivos (tal como a largura do stent ou dimensões da parede) são comparáveis à microestrutura (Figura 15), estatisticamente alguns grãos podem ser maiores do que $o$ ideal $e$ isso pode trazer efeitos danosos na performance mecânica do implante ${ }^{35}$, as previsões numéricas devem ser verificadas, mas o ideal é que sejam medidas no stent que é verdadeiramente o produto acabado ${ }^{36}$.

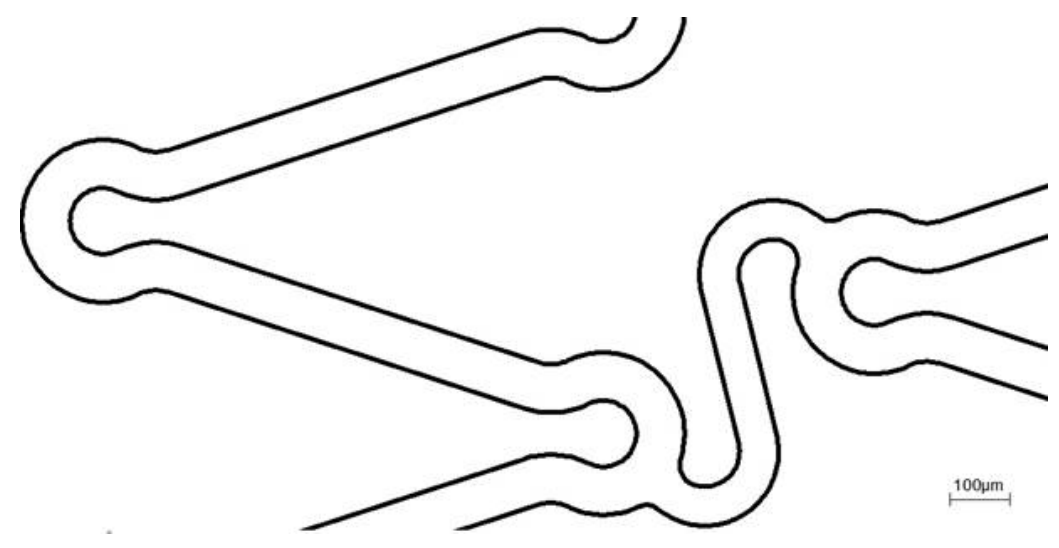

Figura 14 - Parte de desenho planificado de stent, observa-se que as espessuras das estruturas são inferiores a $100 \mu \mathrm{m}$

Existem também fatores que não estão relacionados diretamente ao desenho do stent, mas que podem influenciar sua vida em fadiga, um exemplo é a 
calcificação da artéria que pode provocar uma distribuição não homogênea das forças aplicadas no ciclo cardíaco ${ }^{37}$.

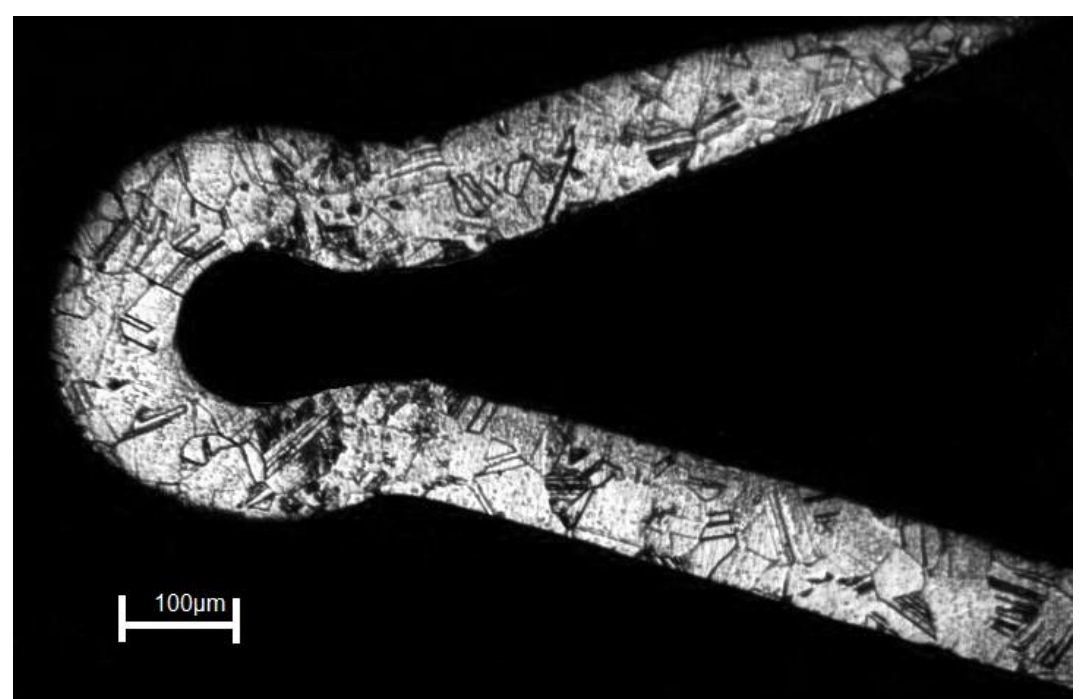

Figura 15 - Metalografia em Stent Cortado e tratado termicamente. Observa-se que as dimensões dos grãos são próximos das dimensões do stent

A doença isquêmica cardíaca é causada por uma obstrução de uma ou mais artérias coronárias, impedindo o fluxo adequado de sangue para o músculo cardíaco, chamado miocárdio. Como qualquer tecido do nosso corpo, o miocárdio, quando privado de seu suprimento de sangue, entra em isquemia e pode sofrer necrose, caracterizando o infarto do miocárdio. Como o mecanismo básico desta doença é uma obstrução da artéria coronária, o tratamento consiste em desobstruíla o mais rápido possível, impedindo que uma isquemia se torne um infarto ${ }^{38}$.

Existem 3 tipos de tratamento para os pacientes com angina causada pela obstrução das artérias coronarianas: tratamento clínico com drogas, cirurgia de "bypass" cardíaco (a famosa ponte de safena) e a angioplastia.

O tratamento clínico com drogas consiste em utilizar-se de medicamentos que reduzem a obstrução na artéria. Este tratamento é ideal para obstruções diagnosticadas com pouco tempo, o que permite um tratamento mais extenso e absolutamente não invasivo.

A cirurgia de ponte de safena, consiste em desviar o fluxo sanguíneo da lesão criando um caminho alternativo para a irrigação ode sangue. Esta técnica é indicada em casos onde não é possível utilizar o stent ou urgentes demais para o tratamento com drogas, e principalmente quando os dois falham. 


\section{MATERIAIS E MÉTODOS}

As amostras foram retiradas de um lote de tubos de CoCr $\mathrm{L} 605 \mathrm{com}$ $1,8 \mathrm{~mm}$ de diâmetro e $0,1 \mathrm{~mm}$ de parede. $O$ tubo segue especificações da norma ASTM F 90 que determina dentre outras coisas a composição que o material deve ter para ser aplicado como implantes cirúrgicos sendo que o mais crítico é a composição química (Tabela 3 e 4).

Tabela 3 - Composição Química da Liga L605, segundo ASTM-F90

\begin{tabular}{lll}
\hline \multirow{2}{*}{ Elemento } & \multicolumn{2}{l}{ Composição (L605) } \\
\cline { 2 - 3 } & Mínimo & Máximo \\
\hline Carbono & 0.05 & 0.15 \\
Manganês & 1.00 & 2.00 \\
Silício & $\ldots$ & 0.40 \\
Fósforo & $\ldots$ & 0.040 \\
Enxofre & $\ldots$ & 0.030 \\
Cromo & 19.00 & 21.00 \\
Niquel & 9.00 & 11.00 \\
Tungstênio & 14.00 & 16.00 \\
Férro & $\ldots$ & 3.00 \\
Cobalto* & Balanço & Balanço \\
\hline
\end{tabular}

*Aproximadamente igual a diferença entre $100 \%$ e a soma da porcentagem dos outros elementos. Não é requerido reportar a porcentagem de cobalto.

Uma série de análises e resultados de testes foram fornecidos pelo fabricante e seguem abaixo:

Fabricante: Minitubes

Lote: BL323

Tabela 4 - Composição Química fornecida pelo fabricante

\begin{tabular}{|c|c|c|c|c|c|c|c|c|c|}
\hline $\mathrm{C}$ & $\mathrm{Si}$ & $\mathrm{P}$ & $\mathrm{S}$ & $\mathrm{Mn}$ & $\mathrm{Ni}$ & $\mathrm{Cr}$ & $\mathrm{Fe}$ & $\mathrm{Co}$ & $\mathrm{W}$ \\
\hline 0,07 & 0,03 & 0,002 & 0,001 & 1,62 & 9,71 & 20,05 & 1,88 & Bal. & 14,94 \\
\hline
\end{tabular}




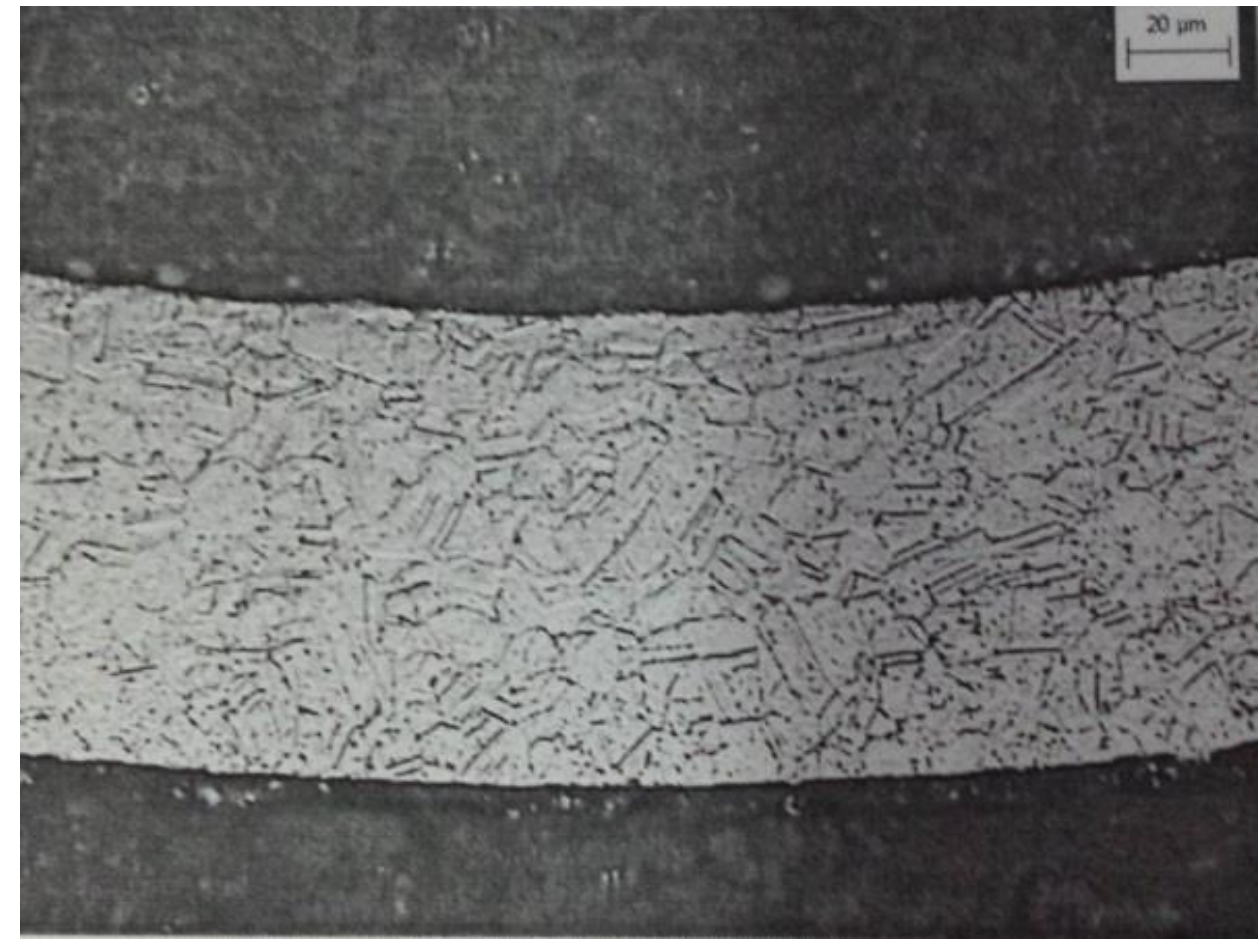

Figura 16 - Imagem metalográfica fornecida pelo fabricante

Tabela 5 - Dados de ensaio de tração fornecidos pelo fabricante

\begin{tabular}{cccc}
\hline & $\begin{array}{c}\text { Resistência } \\
\text { Máxima (MPa) }\end{array}$ & $\begin{array}{c}\text { Limite de } \\
\text { escoamento } \\
\text { a 0,2\% (MPa) }\end{array}$ & $\begin{array}{c}\text { Ductilidade (\% } \\
\text { em 50mm) }\end{array}$ \\
\hline 1 & 1654 & & \\
2 & 1613 & 972 & 15 \\
3 & 1634 & 937 & 17 \\
Média & 1634 & 951 & 17 \\
$\sigma$ (Desvio Padrão) & 16,73 & 953 & 16 \\
\hline
\end{tabular}

O equipamento responsável pela fabricação de stent foi reconfigurado para gerar as amostras a partir do tubo, sendo que as amostras para ensaio de tração um corte simples nas extremidades bastaram para formar secções de tubo de 70mm já amostras para Metalografia, MEV, MET e AFM/EFM foram confeccionadas de forma mais específica. 


\subsection{Tratamento térmico}

O forno utilizado é um forno tubular de resistências do tipo kanthal A1, tubo de cerâmica usinado, corpo de aço inox e isolamento em lã de rocha (Figura 17). O forno foi construído na empresa Innovatech especificamente para fabricação de stents (Figura 17 e 18). Controlado eletronicamente, através da leitura de um termopar do tipo j, o forno é capaz de atingir temperaturas de até $1300^{\circ} \mathrm{C}$. Em conjunto com o forno é utilizado um sistema de alto vácuo comercial do tipo diffstach de fabricação Edwards o que permite tratamentos térmicos em condições de vácuo de pelo menos $1 \times 10-4$.

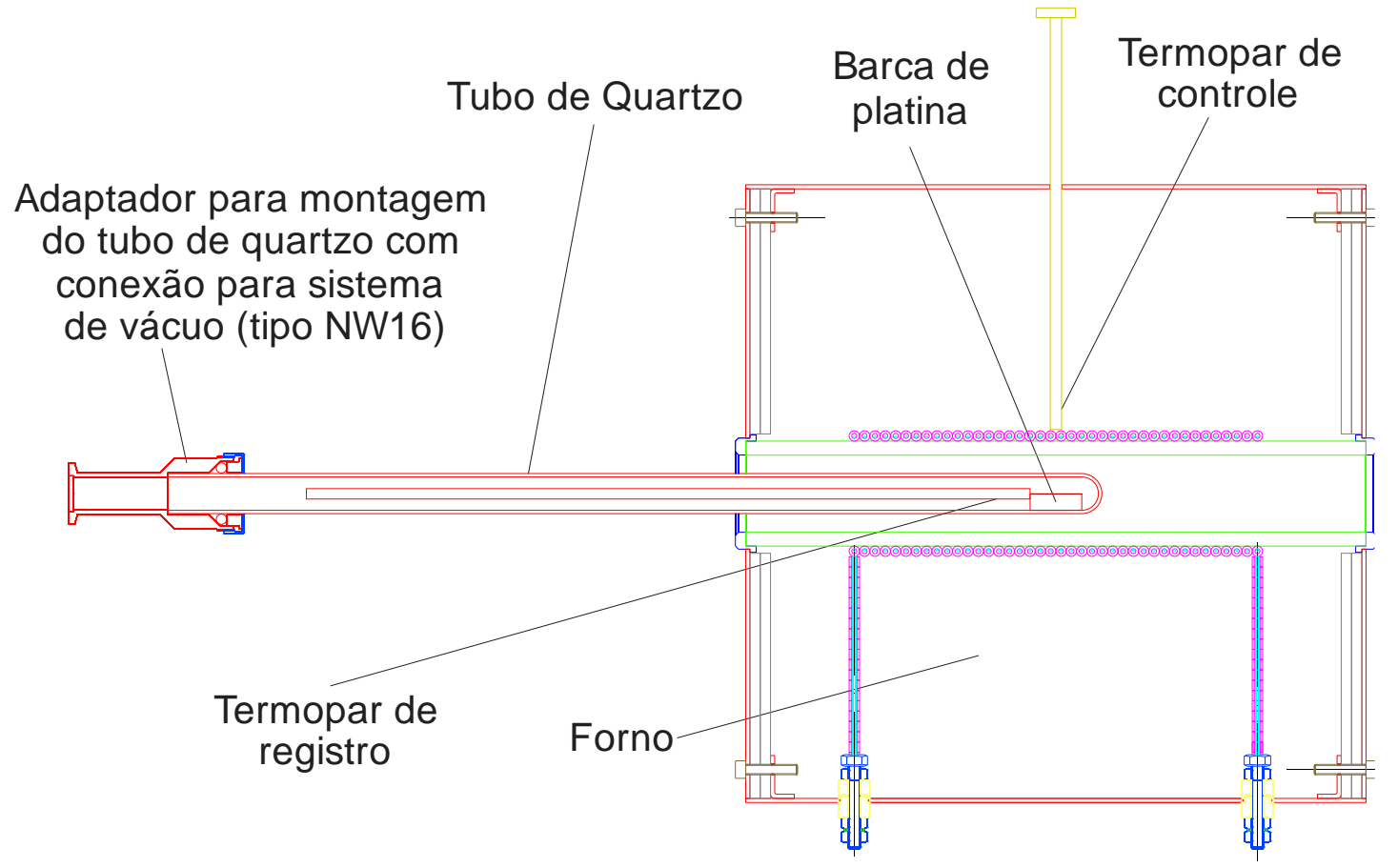

Figura 17 - Desenho esquemático do forno de tratamento térmico

O forno foi montado na posição horizontal preso a um carro sobre trilhos, o que torna mais seguro e controlado o posicionamento de peças e amostras no forno, pois no caso as peças ficam imóveis dentro do tubo de quartzo, enquanto o forno é posicionado em cima das peças e afastado (Figura 18). 


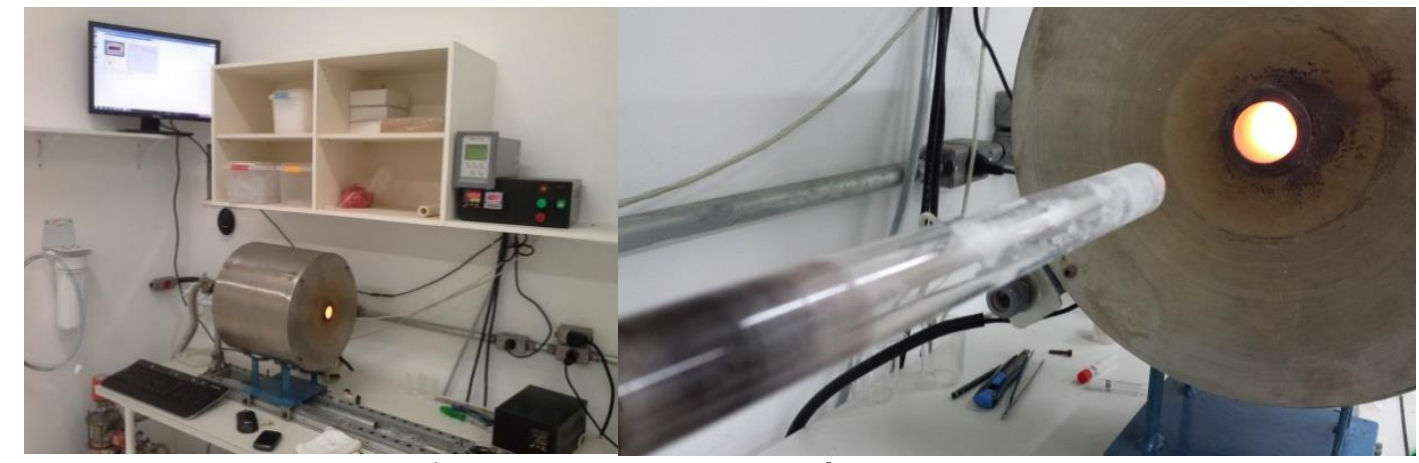

Figura 18 - Detalhes do forno de tratamento térmico

\subsection{Ensaio de Tração}

Foi desenvolvido um dispositivo para os ensaios de tração em tubos, este dispositivo oi inspirado em figura da norma ASTM E $8^{39}$, a qual sugere uma maneira de fixar o tubo para o teste, utilizando-se de dois mandris comuns de furadeira com o fundo roscado, quatro parafusos sendo que o primeiro par é rosqueado nos mandris após ser furado ao centro e roscado. O segundo parafuso é rosqueado no primeiro e por fim uma haste de metal duro é posicionada na extremidade útil do mandril e serve de apoio para prender o tubo (Figura 19).

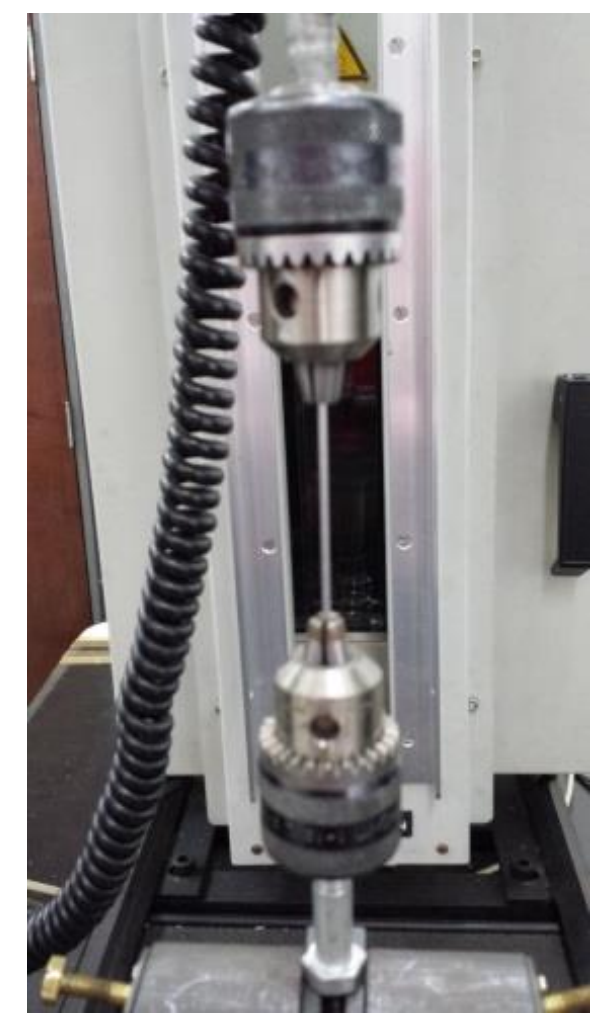

Figura 19 - Imagem do dispositivo de ensaio montado. 
O equipamento utilizado para o ensaio de tração é da marca Instron modelo 5567 , foi utilizada célula de carga de $10.000 \mathrm{~N}$ e a velocidade do ensaio foi $4 \mathrm{~mm}$ por minuto.

Através do software do equipamento, ajustam-se os parâmetros informando as dimensões da secção do tubo e comprimento da amostra, velocidade do ensaio, e inicia-se o ensaio.

O equipamento registra simultaneamente a força exercida sobre a amostra e o deslocamento da ponte, o que permite traçar um gráfico de tensão por deformação.

A partir do gráfico de tensão por deformação, foi calculada a deformação real tomando como pressuposto que a deformação é constante em todo o comprimento do material considerando não haver mudança de volume durante a deformação(Fprmula 1).

Plotando-se o gráfico de tensão/deformações reais, é possível calcular a ttaxa de encruamento do material.

\subsection{Ensaios de tração in situ no MEV}

Adicionalmente, aos ensaios de tração foram feitos dois ensaios em um sistema de tração in situ que funciona em conjunto com um microscópio eletrônico de varredura, afim de visualizar os efeitos das tensões no material durante e após o ensaio.

Foram utilizadas amostras em duas das condições de tratamento térmico utilizadas neste trabalho, 7 minutos a $1175^{\circ} \mathrm{C}$ e 15 minutos a $1250^{\circ} \mathrm{C}$. O equipamento utilizado foi o microscópio eletrônico de varredura modelo MERLIN fabricado pela Carl Zeiss e que possui como assessório um sistema para ensaios de tração in situ (Figura 20). 


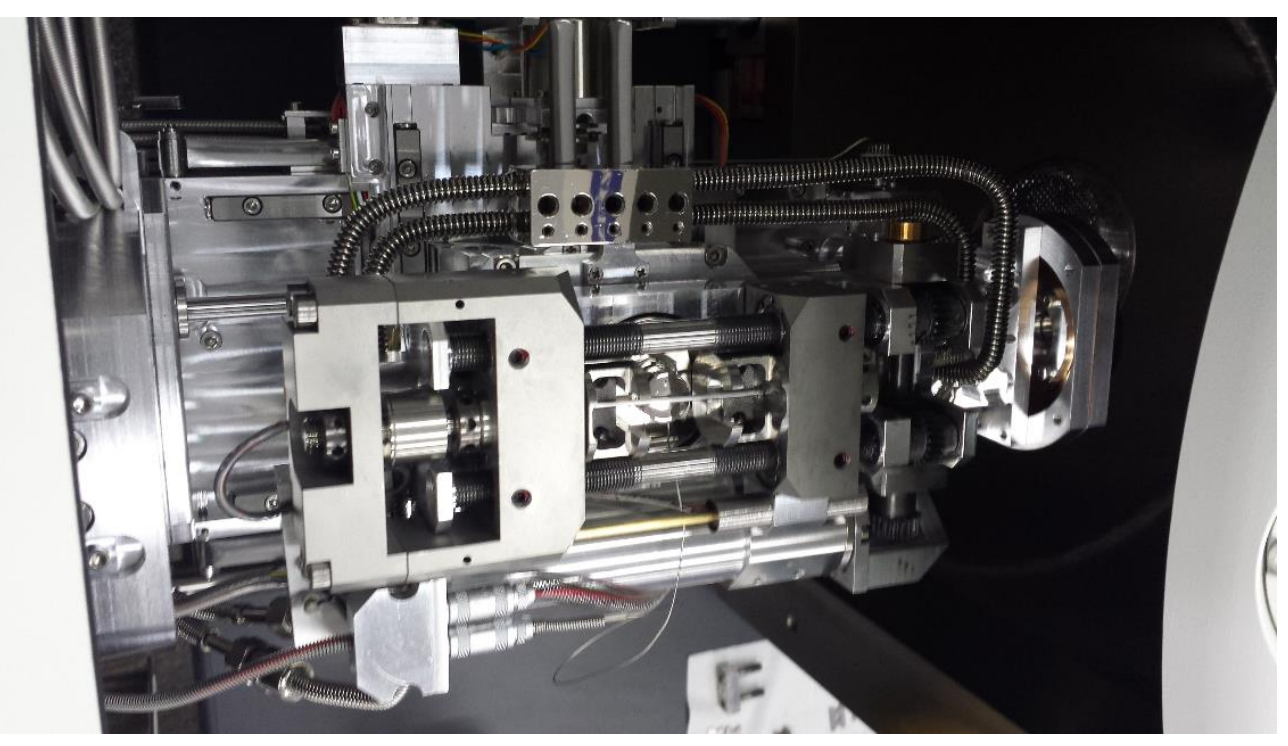

Figura 20 - Equipamento de tração in situ do Instituto de criminalística de São Paulo 


\subsection{Metalografia}

Foram preparadas amostras para a análise metalográfica, o primeiro passo foi o corte a laser, foram cortadas secções do tubo com $24 \mathrm{~mm}$ de comprimento, esta seção possuem as pontas são cilíndricas e uma secção cortada em meia cana, que tem duas funções, a primeira é permitir que a resina penetre até a parede do tubo que será lixada e polida e para melhorar o apoio da mola facilitando assim procedimentos seguintes.

A amostra precisa de um contato elétrico, pois o ataque eletroquímico que revela a estrutura cristalina precisa ser eletrolítico e por este motivo, a amostra preparada é composta de resina, contato elétrico, fio e porta amostra e mola (figura 21).

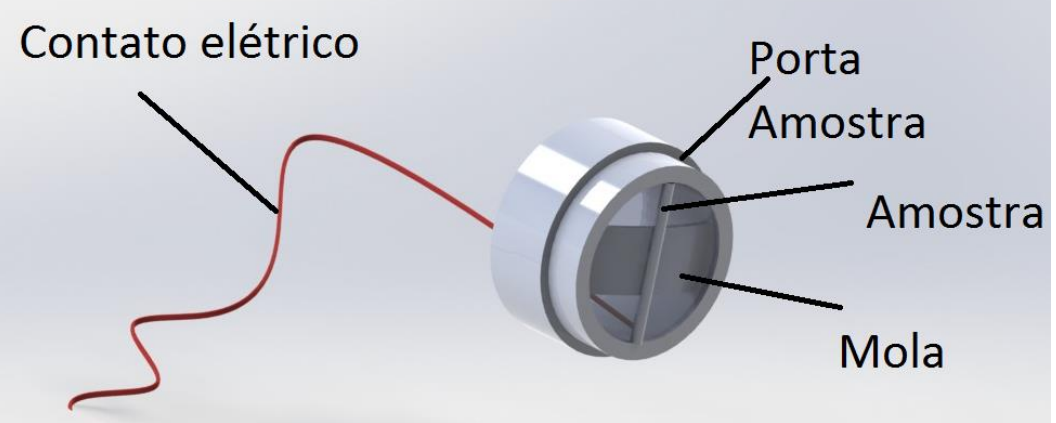

Figura 21 - Desenho da amostra embutida

Para embutimento, as amostras são montadas conforme a figura 22, utilizando-se a moldura e pressionando-se a amostra contra a chapa com uma mola para manter a amostra alinhada com a superfície do fundo. Após a secagem da resina consegue-se uma amostra muito bem alinhada com a superfície da resina.

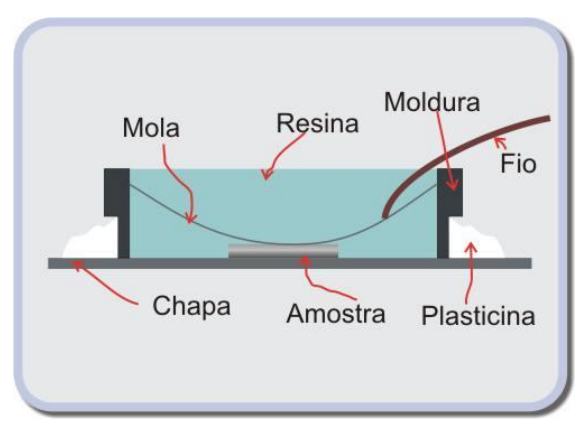

Figura 22 - esquerda montagem utilizada para o embutimento das amostras 
A amostra é lixada com lixa de SiC 1200 ou mais fina. Não devem ser utilizadas lixas de granulações mais grossas, pois o processo de embutimento deixa a amostra posicionada de maneira que permita a remoção de muito pouco material.

O lixamento com lixa 1200 pode ser feito manualmente ou em uma lixadeira. Em ambos os casos, utilizar água corrente. Deve-se tomar cautela para não lixar a amostra em excesso e atravessar a parede do tubo.

Em seguida a amostra é polida em politriz com pasta diamantada de respectivamente $6 \mu \mathrm{m}, 3 \mu \mathrm{m}$ e $1 \mu \mathrm{m}$. Após o polimento a amostra deve estar livre de riscos quando observada ao microscópio.

$O$ ataque eletrolítico que deve ser feito com solução conforme tabela 6 . O ácido oxálico deve estar completamente dissolvido no ácido clorídrico antes de se realizar o ataque. A solução a ser utilizada deve ser preparada no mesmo dia.

Para o ataque, deve-se utilizar o dispositivo de eletropolimento em um béquer de $50 \mathrm{ml}$. A montagem está ilustrada na figura 23.

Os parâmetros te tensão e tempo podem variar um pouco, podendo ser necessário um novo polimento e novo ataque com pequena variação dos parâmetros. $O$ ataque deve ser tal que permita uma observação ao microscópio de todos os contornos de grão em uma imagem.

Tabela 6 - composição da solução utilizada para o ataque eletrolítico das amostras

\begin{tabular}{cc}
\hline Componente & Quant. \\
\hline Ácido Clorídrico P.A. & $95 \mathrm{ml}$ \\
Ácido Oxálico & $5 \mathrm{~g}$ \\
\hline
\end{tabular}

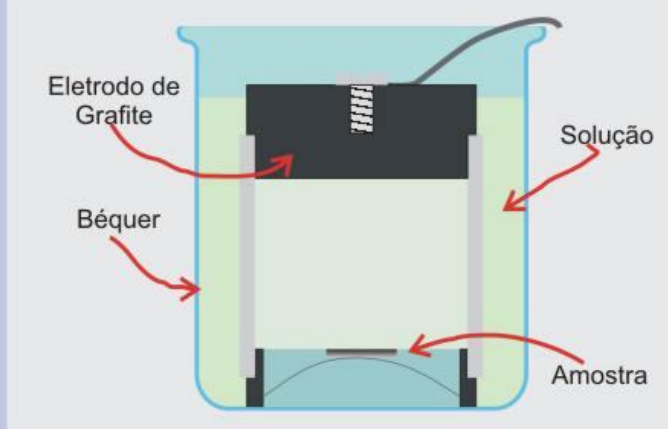

Figura 23 - Montagem utilizada para o ataque eletrolítico das amostras 
O tamanho de grão é obtido de acordo com a norma ASTM E112-82. Utiliza-se o padrão de testes sugerido na norma para a contagem de interceptos, conforme pode ser visto na figura 24 .

A observação das amostras é feita em um microscópio metalográfico da marca OLYMPUS modelo Vanox AHMT13 do laboratório de Microscopia e Microanálise do CCTM com aumentos da entre 200X e 500X dependendo do tamanho de grão do material.

A captura das imagens é feita de forma digital e na maior resolução possível, registrando-se os aumentos do equipamento. Devem ser capturadas imagens do retículo milimetrado tomando cuidado para não mudar configuração do microscópio enquanto alterna da amostra para o reticulo.

O tamanho de grão é medido de acordo com a norma ASTM E112-82. Utiliza-se o padrão de testes sugerido na norma para a contagem de interceptos. $O$ tamanho de grão ASTM é definido de maneira que o tamanho de grão médio de um grão ASTM No em uma ampliação de 100x seja de $32 \mathrm{~mm}$. Assim, para uma ampliação de 100x, temos:

$$
\text { Formula } n^{\circ} 1: \quad \text { ASTM No. }=10,00+2 \log 2(N / L)
$$

Onde $\mathrm{N}$ é o número de contagens e L o comprimento da linha do padrão de intercepto. Pode-se contar tanto o número de interceptos quanto o número de intersecções, devendo-se chegar sempre ao mesmo resultado. Um intercepto é uma parte de segmento que atravessa um grão, enquanto uma intersecção é uma interseção da linha do padrão de testes com o contorno de grão.

Para efetuar esta medição, procede-se da seguinte maneira: Utilizandose o software CorelDraw ou similar, abre-se o arquivo com o padrão de testes. Em seguida, importa-se a imagem da qual se deseja medir o tamanho de grão. a imagem importada é escalada para ficar em uma ampliação de 100X, o que é determinado a partir das fotos do retículo de calibração, uma vez que a foto esteja em escala, copia-se o padrão de testes colocando-o sobre a figura e em seguida, escala-se este padrão até que este esteja em um tamanho adequado para a 


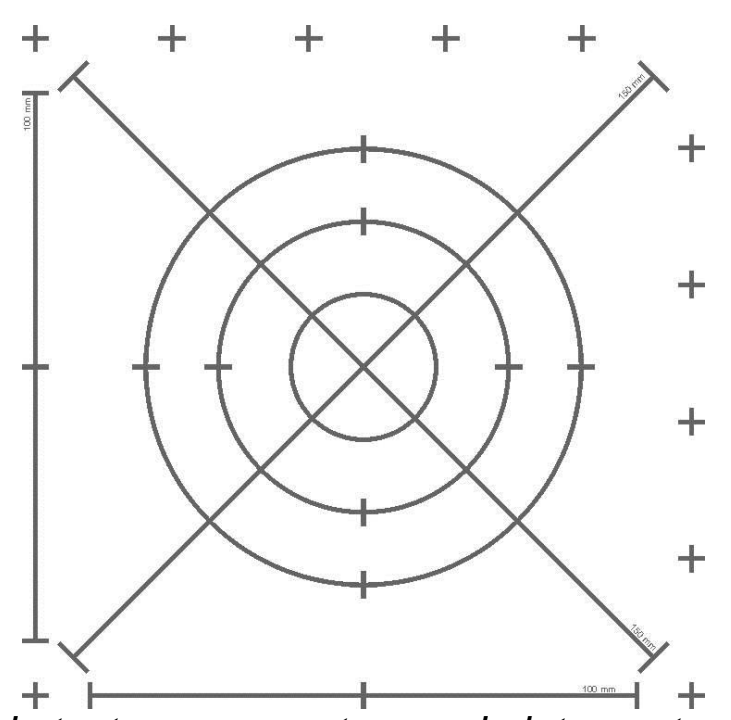

Figura 24 - Padrão de testes para contagem de intercepts sugerido pela norma ASTM E-112

realização da medição. Devem-se evitar contagens totais no padrão menores que 50.

\subsection{Microscopia Eletrônica de varredura}

Assim como a microscopia ótica, o MEV também permite visualizar a microestrutura, e identificar diferentes componentes da liga. A imagem de uma superfície em um microscópio eletrônico de varredura é produzida pelo acumulo simultâneo dos elétrons, quando a superfície da amostra está sendo varrida sistematicamente com um feixe de elétrons focalizado. O MEV combina alta resolução com profundidade de foco, 1000 vezes maior que as possíveis em um microscópio ótico. A preparação das amostras é simples, comparada com a requerida por outras técnicas.

Como o ponto de interesse neste trabalho é principalmente a microestrutura e não a topografia das amostras, as imagens foram formadas preferencialmente por elétrons retroespalhados, ficando imagens em elétrons secundários apenas para stents já eletropolidos.

Para microscopia eletrônica de varredura, as amostras preparadas para metalografia são recobertas pelo método sputtering e submetidas à análise no microscópio eletrônico de varredura, técnica essa que permite visualizar de forma muito clara os precipitados presentes no material e utilizando a ferramenta de E.D.S. é possível comparar qualitativamente as composições das diferentes fases do material. 
As imagens foram obtidas no microscópio eletrônico modelo fabricado pela Philips modelo XL30 Centro de Ciência e Tecnologia dos Materiais (CCTMIPEN/CNEN).

\subsection{Microscopia Eletrônica de Transmissão}

O porta amostras para microscopia eletrônica de transmissão necessita que as amostras sejam de preferência circulares e tenham $3 \mathrm{~mm}$ de diâmetro, esta configuração, é praticamente impossível de se obter nos tubos utilizados para este trabalho pois o diâmetro e externo dos tubos é de $1,8 \mathrm{~mm}$. As amostras preparadas para análise por MET foram cortadas a laser, retirando do tubo cortes circulares. Em razão do diâmetro do tubo ser menor do que o diâmetro da amostra as amostras foram mecanicamente planificadas antes de passar pelo processo de polimento eletrolítico (TENUPOL), que consiste em um processo eletroquímico onde dois jatos de solução são direcionados para a amostra ao mesmo tempo em que uma diferença de potencial é aplicada entre a amostra e o eletrólito. Um sistema de detecção de luz (fotocélula extremamente sensível) passa a operar de forma que o processo seja interrompido imediatamente após ocorrer o início de perfuração na amostra.

Foram feitas algumas tentativas de se analisar partes do tubo sem que tivesse sofrido deformação mecânica, mas todas falharam. Sendo assim, todas as amostras de transmissão foram mecanicamente planificadas o que torna imprecisa qualquer tentativa de obter informações sobre o encruamento da amostra pela técnica de MET. As amostras analisadas permitiram levantar uma idéia geral da presença de precipitados, quantidade e dimensões dos mesmos.

As imagens foram obtidas através do microscópio modelo JEM-2100 do fabricante JEOL no Centro de Ciência e Tecnologia dos Materiais (CCTMIPEN/CNEN).

\subsection{Microscopia de Força Atômica}

Um microscópio de varredura por sonda, ou SPM (Scanning Probe Microscope) é na realidade um grupo de instrumentos compostos basicamente de sonda sensora, cerâmicas piezelétricas para posicionar o objeto amostra e fazer 
varreduras, circuitos de realimentação para controlar a posição vertical da sonda e um computador para mover os scanners de varredura, armazenar dados e os converter em imagens por meio de softwares específicos.

Existem diversos tipos de microscópios de sonda: tais como de tunelamento ou STM (Scanning Tunneling Microscope), de força ou AFM (Atomic Force Microscope), de campo próximo ou SNOM (Scanning Near-Field Optical Microscope) e todos os derivados.

O componente essencial do SPM é o sensor, com o qual consegue-se sondar as amostras e obter as imagens com magnificações muito altas, de forma tal que podem ser medidas distâncias com resolução de até 0,1 ângstrom $(1 \AA=10$ $10 \mathrm{~m})$.

Os sensores usados neste tipo de aparelhos são: para o microscópio de tunelamento, uma ponta metálica para fazer tunelamento entre ela e a amostra; para o microscópio de força atômica, um sensor de força em forma de ponta condutora ou isolante.

No presente trabalho, a técnica utilizada para a obtenção das imagens foi microscopia de força atômica combinada com microscopia de força elétrica ou microscopia de força Kelvin. Nesta técnica, são coletados simultaneamente informações da topografia da amostra pela leitura de força atômica, e da condutividade elétrica na mesma amostra.

A amostra analisada passou pela mesma sequência de fabricação do stent coronário, ou seja: corte, decapagem, tratamento térmico e eletropolimento.

As imagens foram obtidas utilizando o equipamento NanoScope Multimode SPM(Figura 25) fabricado pela Digital Instruments - Veeco.

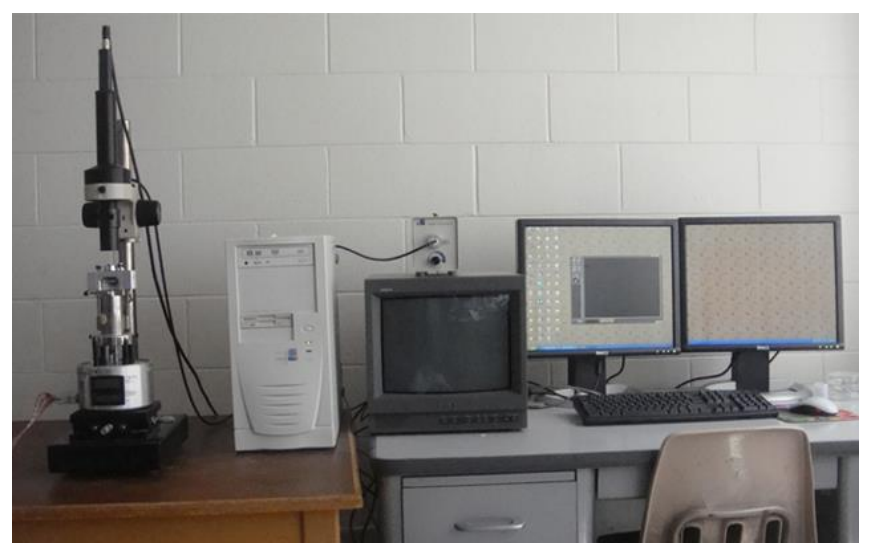

Figura 25 - Microscópio de varredura por sonda, presente no laboratório de filmes finos 


\section{RESULTADOS}

\subsection{Tratamento térmico}

Foi feita uma calibração do forno (Figura 26) para determinar a zona útil para o tratamento térmico, tomando como base a posição do termopar com relação à entrada do forno e desta forma definir uma zona útil para o mesmo. Para este procedimento, o controlador do forno foi configurado para três temperaturas, coincidentemente as mesmas temperaturas utilizadas para

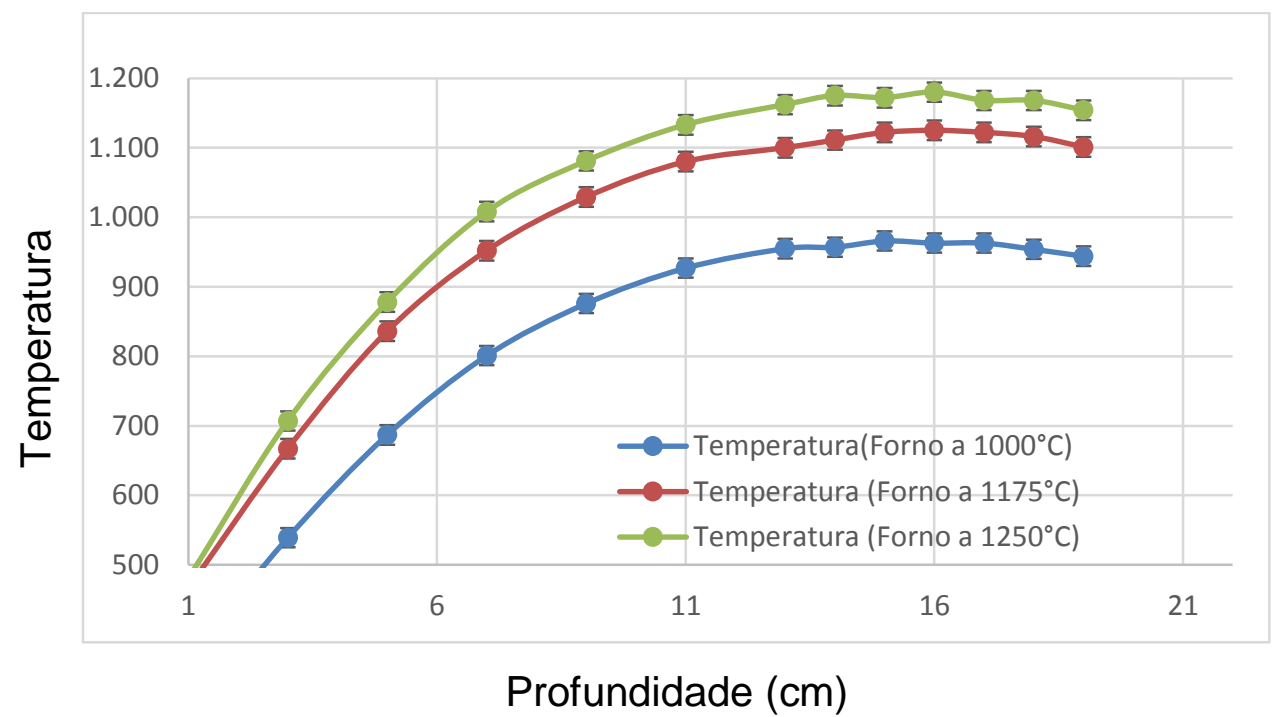

Figura 26 - Calibração do forno nas temperaturas trabalhadas

Como referência, o forno foi ajustado para as temperaturas usadas neste trabalho $\left(1000^{\circ} \mathrm{C}, 1175^{\circ} \mathrm{C}\right.$ e $\left.1250^{\circ} \mathrm{C}\right)$, e posição do termopar no forno até a posição mais interna que a configuração permite e foi tomada a medida da temperatura em cada posição deixando o termopar atingir o equilíbrio em cada posição.

A partir desta calibração foi possível definir a área útil do forno tomandose como base que a temperatura de tratamento térmico é igual a temperatura nominal mais ou menos $14^{\circ} \mathrm{C}$.

O resultado permitiu definir que o termopar deve ficar a 16 centímetros da entrada do forno, desta forma o comprimento útil do forno fica entre as posições $13 \mathrm{~cm}$ e $19 \mathrm{~cm}$ resultando em $6 \mathrm{~cm}$ de comprimento útil. 
A temperatura medida no termopar dentro do tubo de quartzo juntamente com as amostras, indica que leva-se até 4 minutos para atingir a temperatura calibrada, e por este motivo não foram feitos tratamentos por períodos inferiores a 4 minutos pois poderiam sequer chegar à temperatura determinada no plano. (Figura 27).

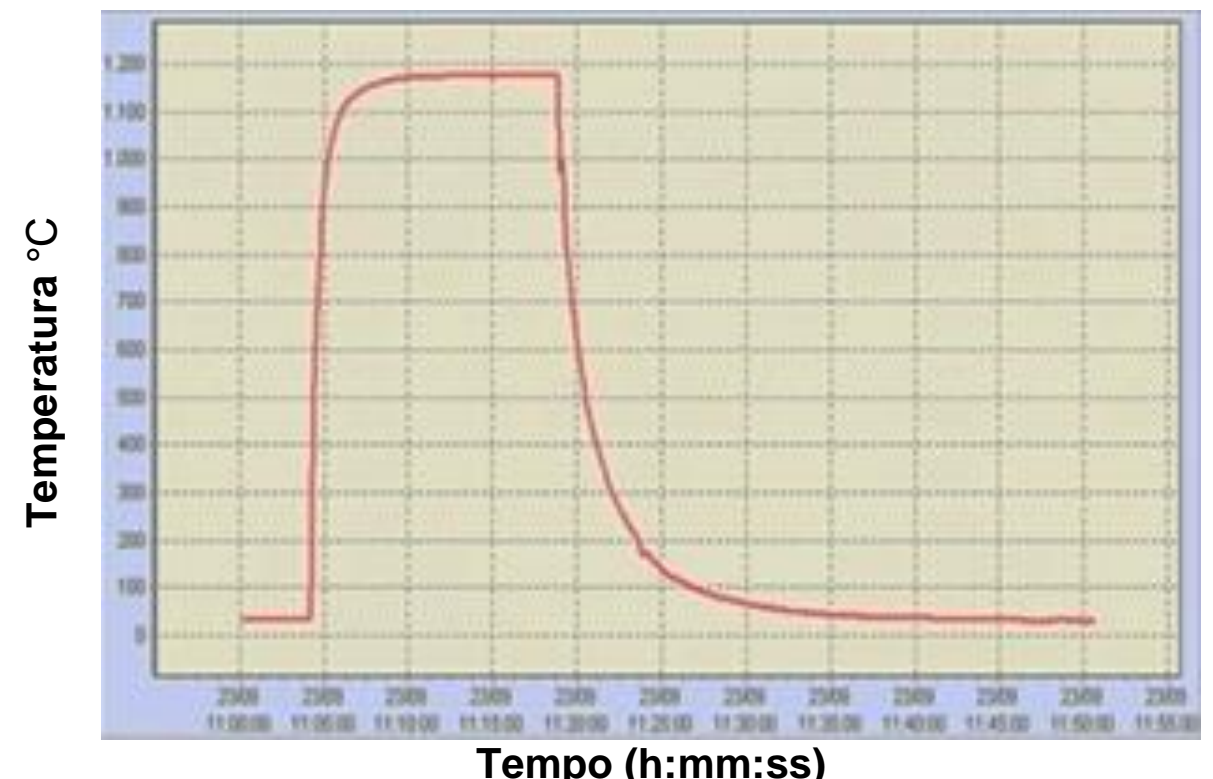

Figura 27 - Leitura do termopar de registro durante o tratamento térmico

\subsection{Ensaios de tração}

Foram preparadas amostras para ensaios com 17 condições diferentes, sendo uma sem tratamento térmico, e as 12 demais condições de tratamento térmico que combinam três temperaturas, uma com resfriamento rápido, uma com tempo prolongado no forno.

As amostras foram cortadas a laser todas com o comprimento de $70 \mathrm{~mm}$, e no momento do ensaio de tração, foram presas deixando $40 \mathrm{~mm}$ de espaço entre os mandris utilizados para fixação. Como o equipamento de tração possui um preciso sistema de posicionamento, a posição da ponte foi utilizada como referência para garantir para todas as amostras o mesmo comprimento útil.

Os ensaios em amostras em condições identicas de tratamento térmico, apresentaram resultados equivalentes, idênticos no limite de escoamento e a ductilidade, porém com variações inferiores a $5 \%$ o que significa uma variação 
inferior ao que se espera para um ensaio de tração, por esse motivo, e pelo fato de o material ser relativamente caro ( $R \$ 360,00$ o metro de tubo) evitou-se para este trabalho repetir ensaios que não tenham apresentado algum tipo de problema de percurso como escoregamento durante a tração ou deformações ocorridas durante a fixação da amostra no dispositivo.

Por conta do comprimento útil do forno disponível, ser inferior a $200 \mathrm{~mm}$ (comprimento total solicitado em norma técnica ASTM E8), e pelo fato de não haver disponibilidade de extensômetro nos laboratórios, os dados de ductilidade, e encruamento são considerados neste trabalho foram obtidos em relação ao comprimento da amostra entre as fixações.

Pelo fato de as amostras serem bastante dúcteis, com deformações que chegam a 57\%, a imprecisão causada pela falta de um extensômetro fica bastante diminuida, ainda assim esta ductilidade deve ser tratada como qualitativa. Os dados de limite de escoamento e tensão máxima são válidos quantitativamente pois dependem apenas da fixação da amostra e da precisão da célula de carga, fatores esses que independem da norma técnica utilizada e também da existência ou não de estensômetro.

Após testes mecânicos foi determinado que seu o limite de escoamento a $0,2 \%$ de deformação plástica é de $1170 \mathrm{MPa}$, o limite de resistência é de 1.633MPa e a ductilidade é igual a 17\%(Figura 28). Estes valores de resistência mecânica são superiores a praticamente qualquer aço comercial, explicam o porquê dessa liga ser classificada como superliga. 


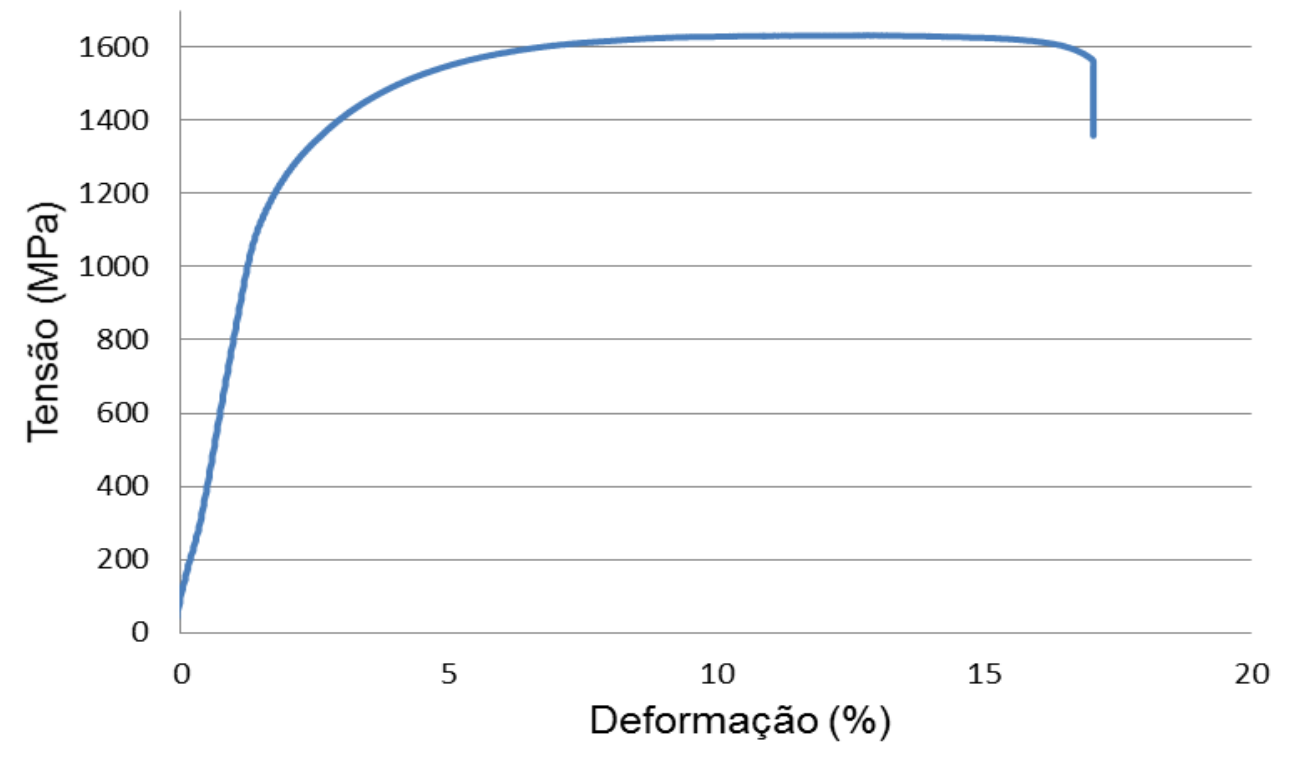

Figura 28 - Resultado de ensaio de tração da liga de CoCr L605 como recebido

Na figura 28 é possível observar, que a transição entre deformação elástica e deformação plástica é indefinida, e que apesar da altíssima resistência mecânica isso se dá pelo fato de o material ainda estar encruado pelo processo de trefilação na fabricação do tubo e a ductilidade é de apenas $17 \%$, ou seja, muito menor do que se espera para o mesmo material recozido.

O material que apresenta comportamento como no gráfico da figura 28 ( ou seja, grande resistência mecânica e pouca ductilidade) é um bom material para muitas aplicações, como por exemplo molas, estruturas rígidas, etc. no entanto não é adequado para a aplicação como stent coronário pois este material ao ser "crimpado" em um balão inflável, recupera boa parte de seu diâmetro e se desprende do balão. No mesmo sentido, supondo que se consiga prender o stent ao balão, no momento de colocá-lo na artéria coronária, é necessária bastante pressão no balão para expandir o stent contra as paredes da artéria, e ao se retirar o balão o stent como uma mola vai diminuir o diâmetro e este processo faz com que o stent fique solto na artéria com risco de se movimentar.

No gráfico da figura 29, estão sobrepostas os resultados de ensaio de tração das amostras tratadas termicamente a $1000^{\circ} \mathrm{C}$, é possível identificar uma equivalência de resultados, desde a amostra que ficou por 4 minutos no forno aquecido quanto à amostra que ficou 15 minutos. 


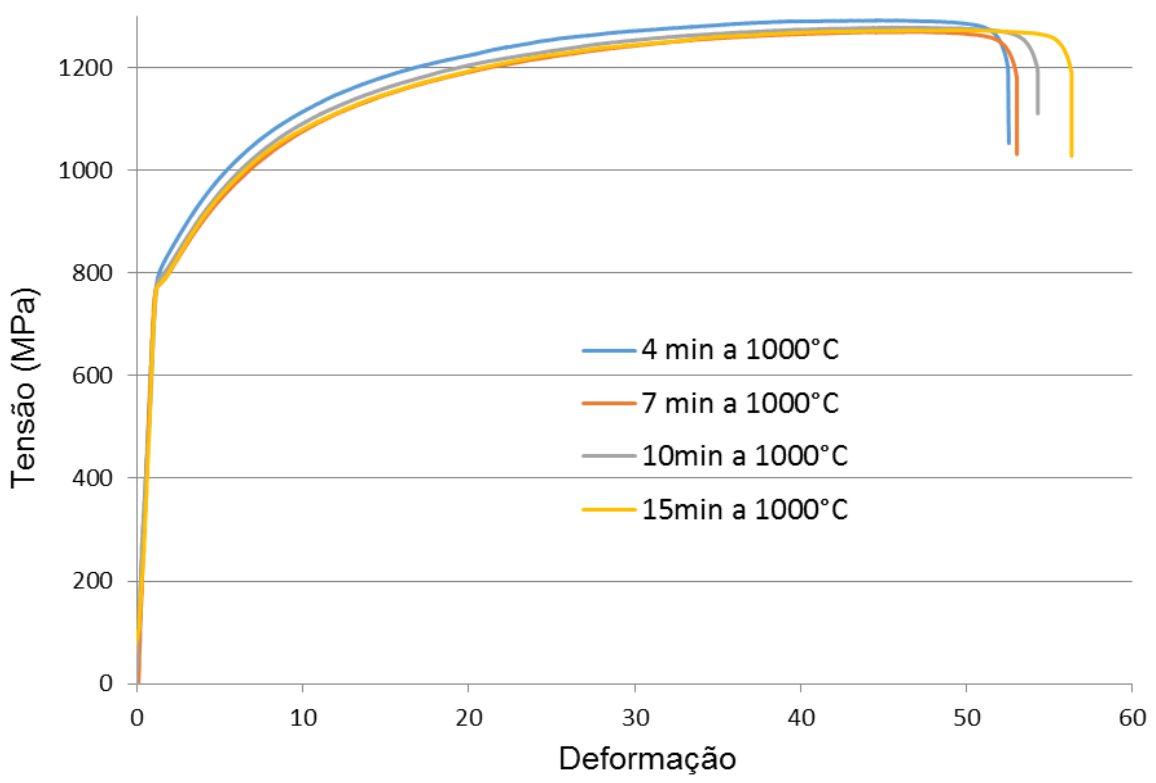

Figura 29 - Gráfico das amostras tratadas a $1000^{\circ} \mathrm{C}$ por 4,7,10 e 15 minutos

Esta equivalência demonstra que a $1000^{\circ} \mathrm{C}$, o material perde 0 encruamento original, derrubando o limite de escoamento a 0,2\% de deformação plástica de $1170 \mathrm{MPa}$ (material como recebido) para em torno de 790MPa. A tensão máxima caiu de 1633Mpa para em torno de 1270Mpa mas a ductilidade que no material encruado é de $17 \%$, no tratamento térmico a $1000^{\circ} \mathrm{C}$ todas as condições ficaram acima de 50\% de deformação máxima.

No gráfico da figura 30 estão sobrepostos os resultados de ensaio de tração das amostras tratadas a $1175^{\circ} \mathrm{C}$, diferentemente das amostras tratadas a $1000^{\circ} \mathrm{C}$, a diferença de comportamento mecânico entre elas é evidente, a amostra tratada a $1175^{\circ} \mathrm{C}$ por 4 minutos apresenta limite de escoamento e tensão máxima muito superiores às amostras tratadas por 15 minutos respectivamente limite de escoamento 480MPa contra 410MPa e 1027 contra 812MPa.

Curiosamente a amostra tratada por 15 minutos mostrou resistência e ductilidades maiores do que a amostra tratada por 10 minutos, este resultado provavelmente se explica por alguma diferença pontual no material(tolerância dimensional no limite superior), sendo este o único ponto onde o tratamento mais agressivo resultou em um comportamento mecânico melhor do que o tratamento menos agressivo em termos de tempo versus temperatura. 


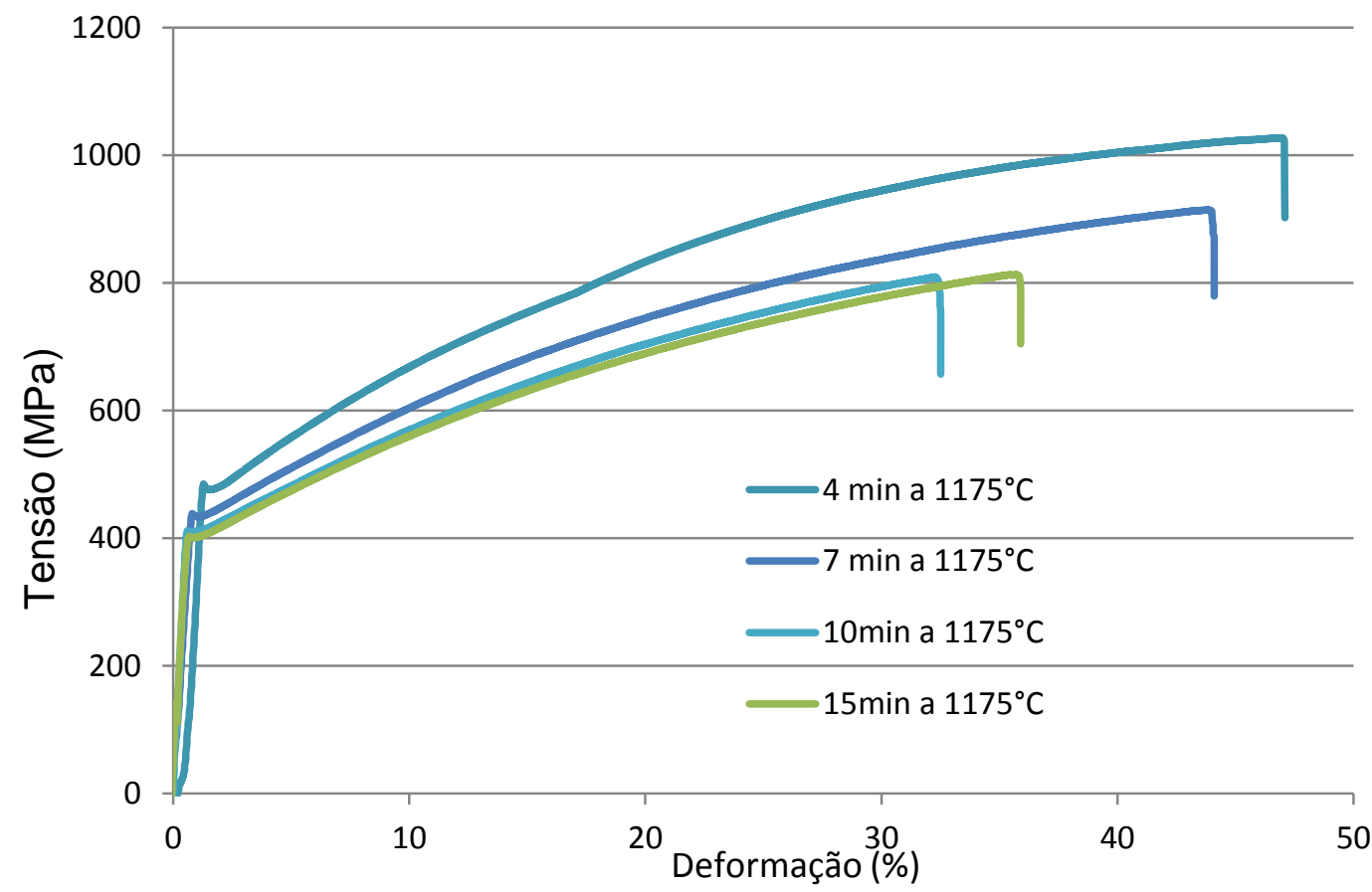

Figura 30 - Gráfico das amostras tratadas a $1175^{\circ} \mathrm{C}$ por 4,7,10 e 15 minutos

Para aplicação como stent, os tratamentos térmicos a $1175^{\circ} \mathrm{C}$ por 4 e 7 minutos levou o material ao comportamento mecânico mais adequado até agora para a aplicação como stent, com o limite de escoamento acima de 400MPa, nos dois casos, é baixo o suficiente para evitar que o stent se comporte como uma mola, e alto o suficiente para permitir uma força radial elevada sem a necessidade de aumentar a secção das estruturas. A ductilidade nessas temperaturas também é elevada, permitindo que o stent possa ser crimpado no balão e expandido na coronária sem risco de ocorrer fratura.

Os tratamentos térmicos à temperatura de $1250^{\circ} \mathrm{C}$ resultaram em perda expressiva de propriedades mecânicas(Figura 31), sendo que o limite de escoamento mostrou uma certa estabilidade enquanto os resultados de ductilidade e tensão máxima mostram uma tendência quase linear de perda de propriedades mecânicas.

Com relação ao limite de escoamento, apenas o tratamento por 4 minutos mostrou resultados aceitáveis para a aplicação como stent, os demais apresentaram limite de escoamento inferior a 400MPa, resultado que se aproxima dos obtidos com materiais menos nobres como inox 316L. No quesito da ductilidade, tendo como base uma ductilidade ideal acima de 50\% e aceitável até $40 \%$, nenhuma das amostras apresentou ductilidade suficiente, aplicando-se esta 
característica ao stent, obtem-se uma alta probabilidade que este frature na crimpagem e na expansão do balão

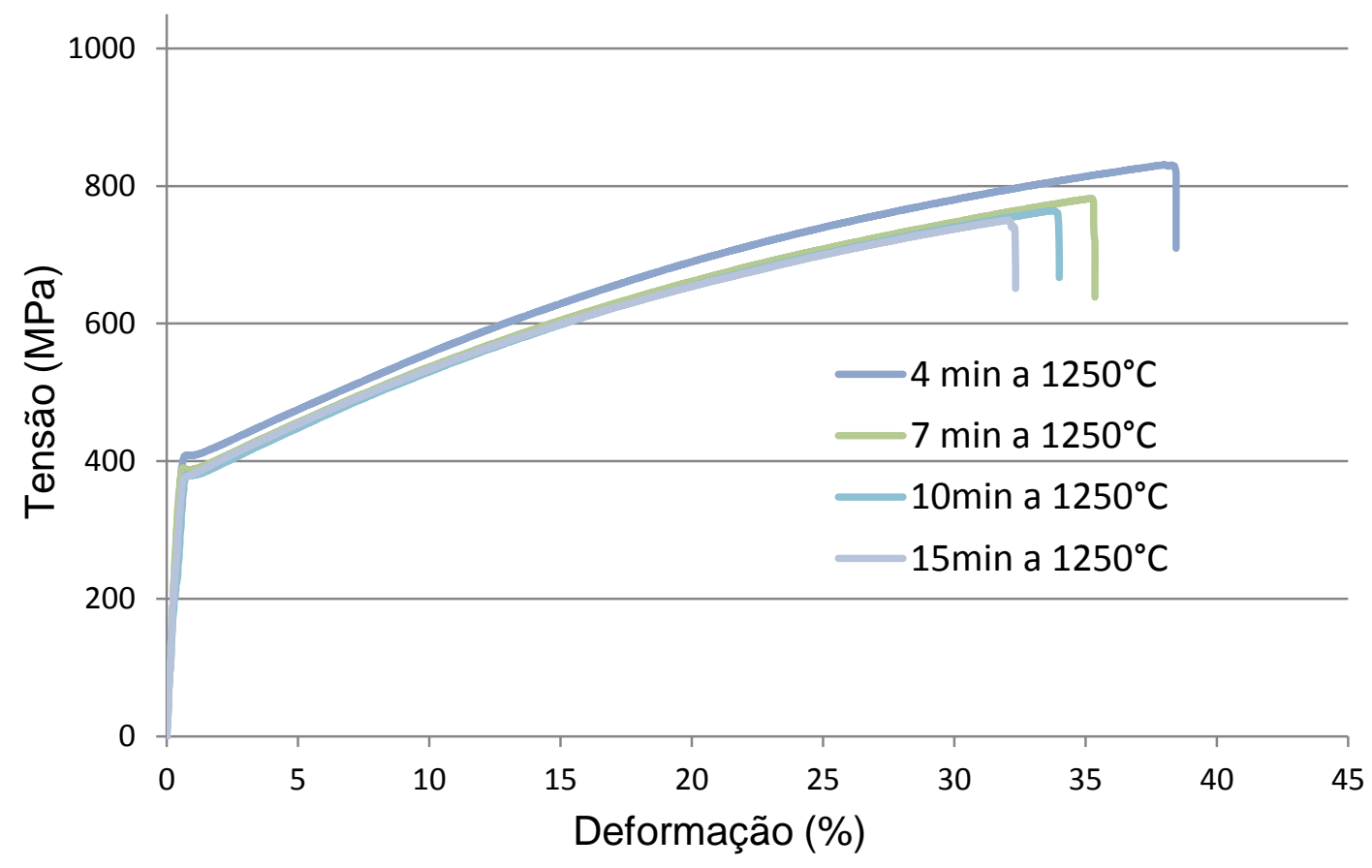

Figura 31 - Gráfico das amostras tratadas a $1250^{\circ} \mathrm{C}$ por 4,7,10 e 15 minutos

Uma experiência para aprimorar as propriedades mecânicas do material, foi tentar induzir uma tensão residual no material por resfriamento rápido(têmpera). O resultado foi positivo no sentido de melhorar as propriedades mecânicas em porcentagem(Figura 32), no entanto as especificações mínimas para propriedades mecânicas de projeto para o design de stent utilizado são: Limite de escoamento a 0,2\% 500MPa, tensão máxima 1000MPa e ductilidade 50\% ao mesmo tempo que se eliminariam todos os precipitados; a tentativa não funcionou para o objetivo porem houve um aumento significativo nos resultados de limite de escoamento. 


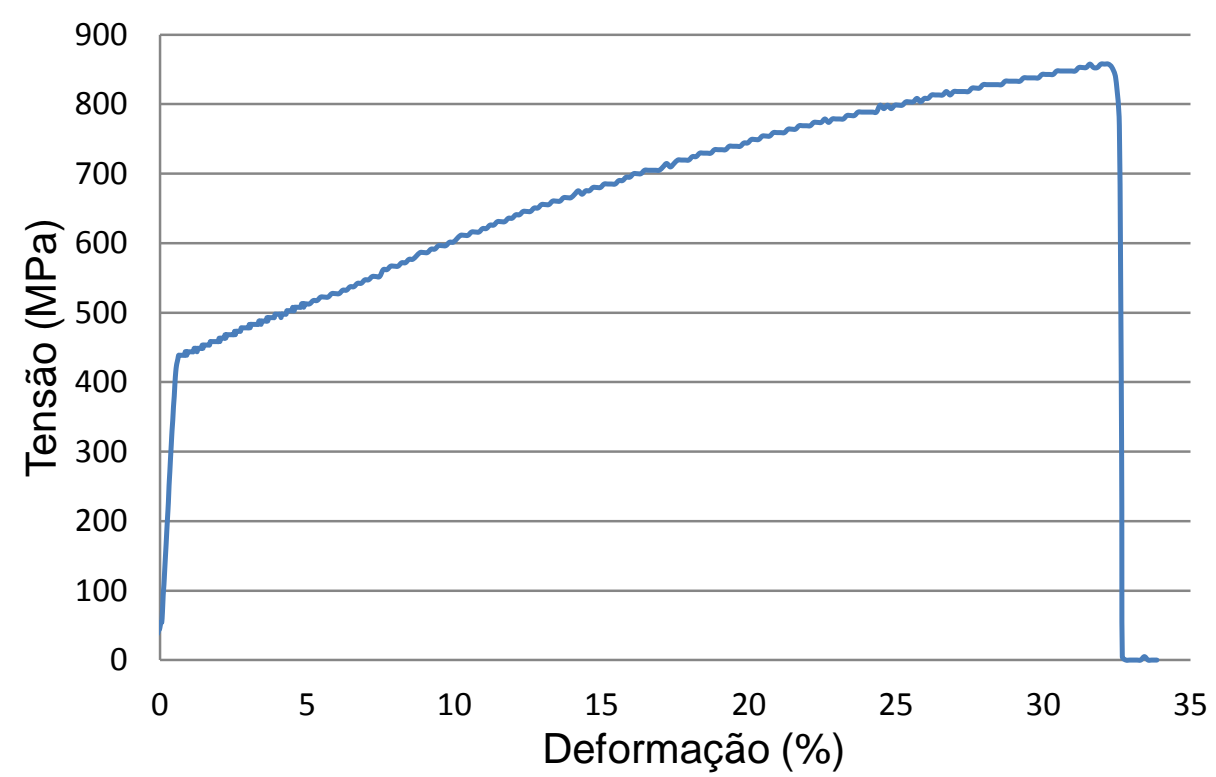

Figura 32 - Amostra tratada a $1250^{\circ} \mathrm{C}$ por 4 minutos e resfriada rapidamente (têmpera)

Outro ensaio para adequação das características mecânicas do material foi adicionar um ciclo de envelhecimento a $860^{\circ} \mathrm{C}$, por uma hora ao material; talvez por ter levado pouco tempo o envelhecimento, não melhorou o resultado de limite de escoamento(Figura 33) embora o limite de resistência esteja maior do que os outros dados apresentados na tabela 7.

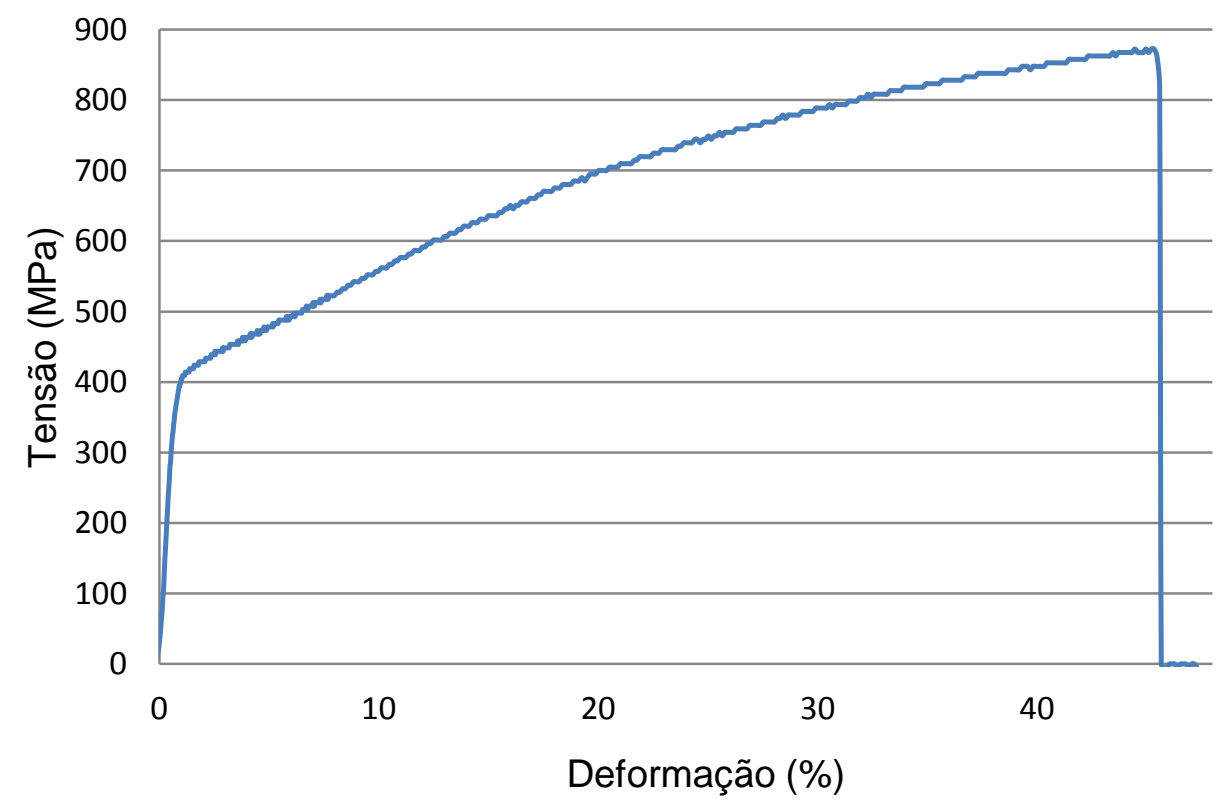

Figura 33 - Amostra tratada a $1250^{\circ} \mathrm{C}$ por 4 minutos e envelhecida a $850^{\circ} \mathrm{C}$ por 60 minutos 
Após os tratamentos térmicos, os resultados de limite de escoamento das amostras tratadas a $1000^{\circ} \mathrm{C}$ foram próximas de $800 \mathrm{MPa}$ em todos os tempos de tratamento térmico, o que indica que uma vez aliviada a tensão do encruamento pré-existente, não houve transformação significativa na microestrutura para estas amostras enquanto nas demais temperaturas de tratamento térmico $\left(1175^{\circ} \mathrm{C}\right.$ e $1250^{\circ} \mathrm{C}$ ) houve uma convergência para valores próximos de $390 \mathrm{MPa}$.

Tabela 7 - Resultados dos ensaios de tração

\begin{tabular}{ccccc}
\hline Temperatura $\left({ }^{\circ} \mathrm{C}\right)$ & $\begin{array}{c}\text { Tempo } \\
\text { (minutos) }\end{array}$ & $\begin{array}{c}\text { Limite de } \\
\text { Resistência } \\
(\mathrm{MPa})\end{array}$ & $\begin{array}{c}\text { Limite de } \\
\text { escoamento } \\
(\mathrm{MPa})\end{array}$ & $\begin{array}{c}\text { Ductilidade } \\
(\%)\end{array}$ \\
\hline 1000 & 4 & 1292 & 795 & 53 \\
& 7 & 1270 & 776 & 53 \\
& 10 & 1278 & 790 & 54 \\
1175 & 15 & 1273 & 777 & 56 \\
\hline & 7 & 1027 & 480 & 57 \\
& 10 & 915 & 435 & 44 \\
& 15 & 809 & 410 & 33 \\
1250 & 4 & 830 & 400 & 36 \\
\hline 1250 resfriado & 7 & 782 & 390 & 38 \\
em óleo & 4 & 764 & 380 & 34 \\
\hline $1250+$ aging a & $4+60$ & 872,38 & 384 & 36 \\
$860^{\circ} \mathrm{C}$ & 15 & 750 & 380 & 36 \\
\hline
\end{tabular}

Os resultados de limite de resistência bem com os de ductilidade diminuíram na medida em que foram expostos, por mais tempo a altas temperaturas (maiores que $1150^{\circ} \mathrm{C}$ ), tendendo a estabilizar em 750MPa e 380Mpa respectivamente. Já a ductilidade não demonstrou tendência a convergir sendo decrescente na medida em que se aumenta a agressividade do tratamento térmico.

Analizando os gráficos de tensão por deformação reais(Figura 34), as amostras tratadas a $1000^{\circ} \mathrm{C}$ mostraram uma taxa de encruamento menor do que as demais amostras, porém parecidas entre si. O que significa que o material endurece mais lentamente do que nos demais tratamentos térmicos. 


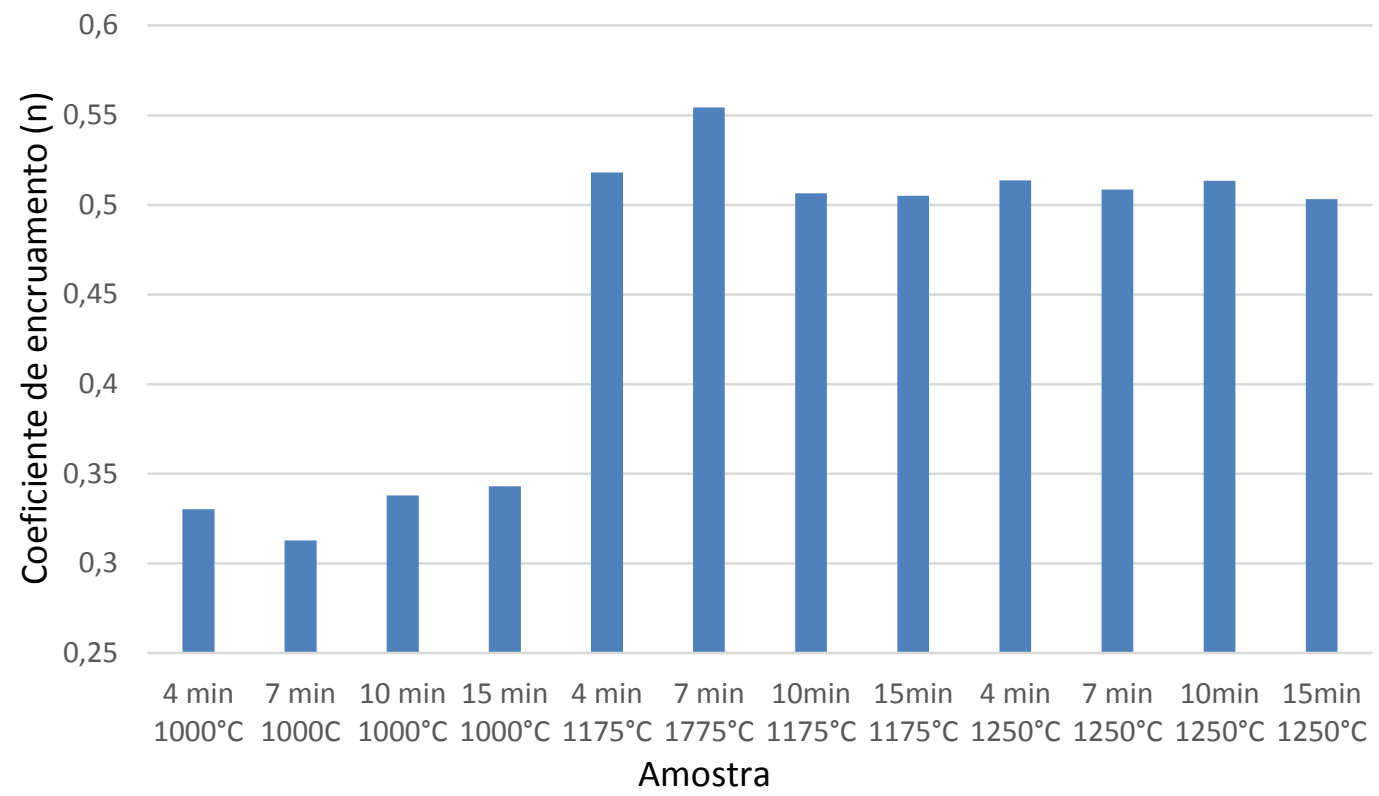

Figura 34 - Coeficientes de encruamento do material após tratamento térmico

Os resultados das amostras tratadas a $1175^{\circ} \mathrm{C}$ e $1250^{\circ} \mathrm{C}$ também mostraram uma equivalência entre si porem com uma expressiva diferença com relação ao material tratado a $1000^{\circ} \mathrm{C}$, isso ocorre provavelmente porque a $1000^{\circ} \mathrm{C}$ ainda se está longe da temperatura de fusão da amostra, enquanto a partir de $1175^{\circ} \mathrm{C}$ já temos condição de solubilização (solution aneealing), tal que as transformações na microestrutura são mais evidentes do que no tratamento térmico a $1000^{\circ} \mathrm{C}$.

\subsection{Ensaios de Tração in situ no MEV}

Os ensaios de tração in situ mostraram resultados de módulo de elasticidade e limite de escoamento semelhantes aos ensaios com mesmo tratamento térmico, porém as amostras escorregaram da fixação antes de romper durante 0 ensaio, 0 que exclui os resultados de limite de resisência $e$ ductilidade(Figuras 35 e 36). 


\section{L605 $7 \mathrm{~min}$ a $1175^{\circ} \mathrm{C}$ in situ}

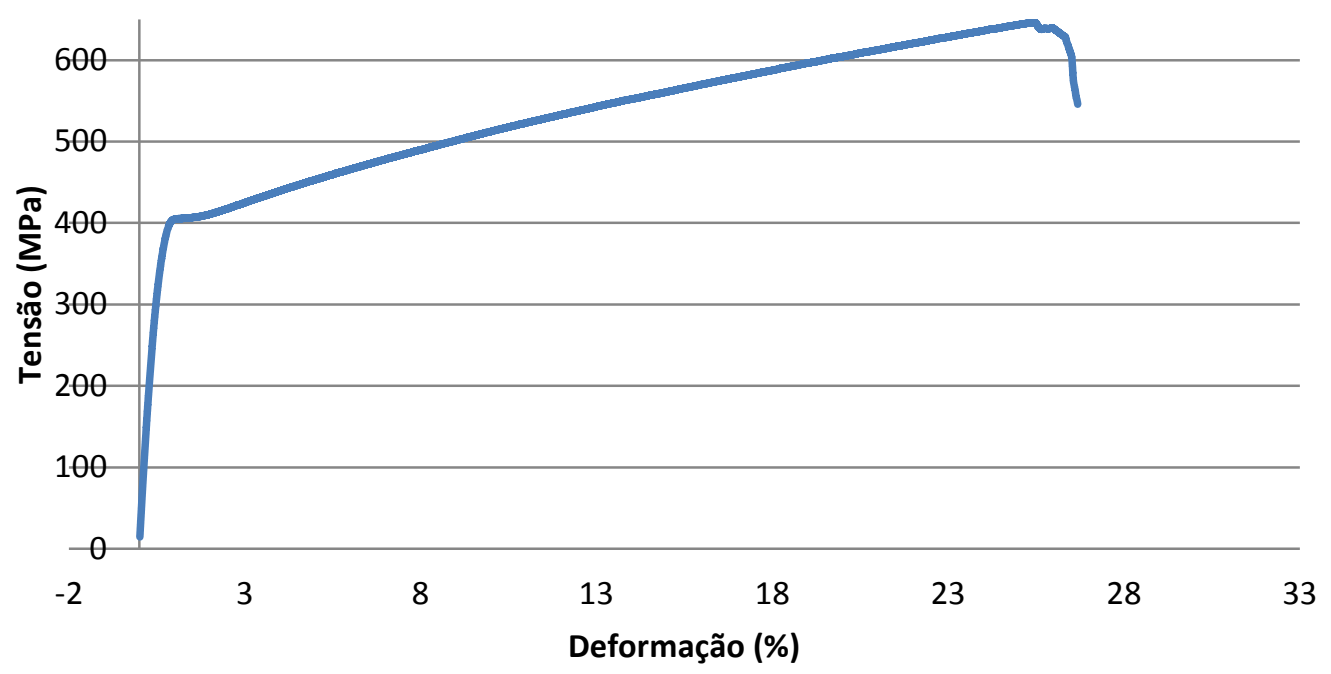

Figura 35 - $A$ amostra tratada a $1175^{\circ} \mathrm{C}$ por 7 minutos apresentou Limite de escoamento: de 362MPa e módulo de elasticidade de 793,21 GPa

\section{L605 $15 \mathrm{~min}$ a $1250^{\circ} \mathrm{C}$ in situ}

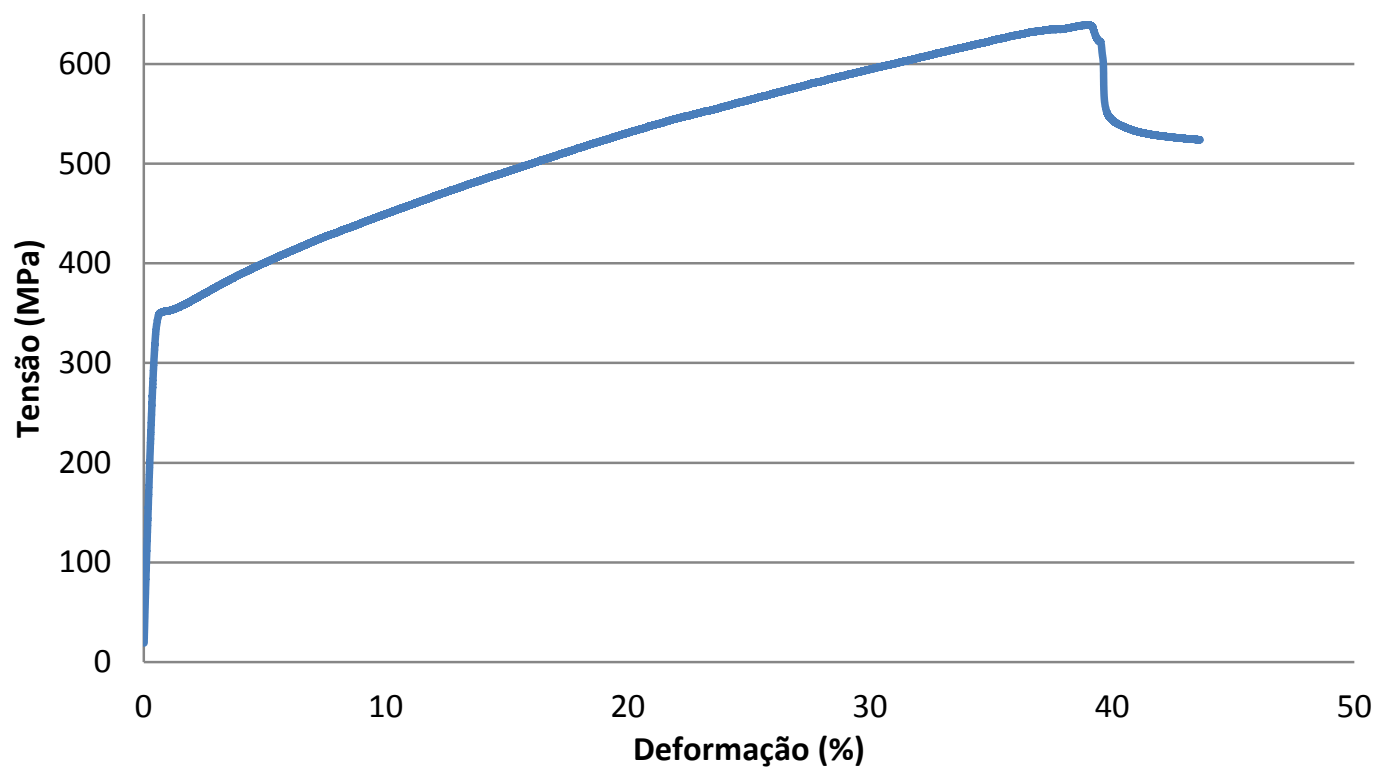

Figura 36 - A amostra tratada a $1250^{\circ} \mathrm{C}$ por 15 minutos apresentou Limite de escoamento: de 349MPa e módulo de elasticidade de 780GPa

O ensaio de tração in situ, permitiu visualizar a maneira como o material se deforma plasticamente, é possível observar estrias na imagem capturada no MEV após o ensaio(Figuras 37 e 38). 


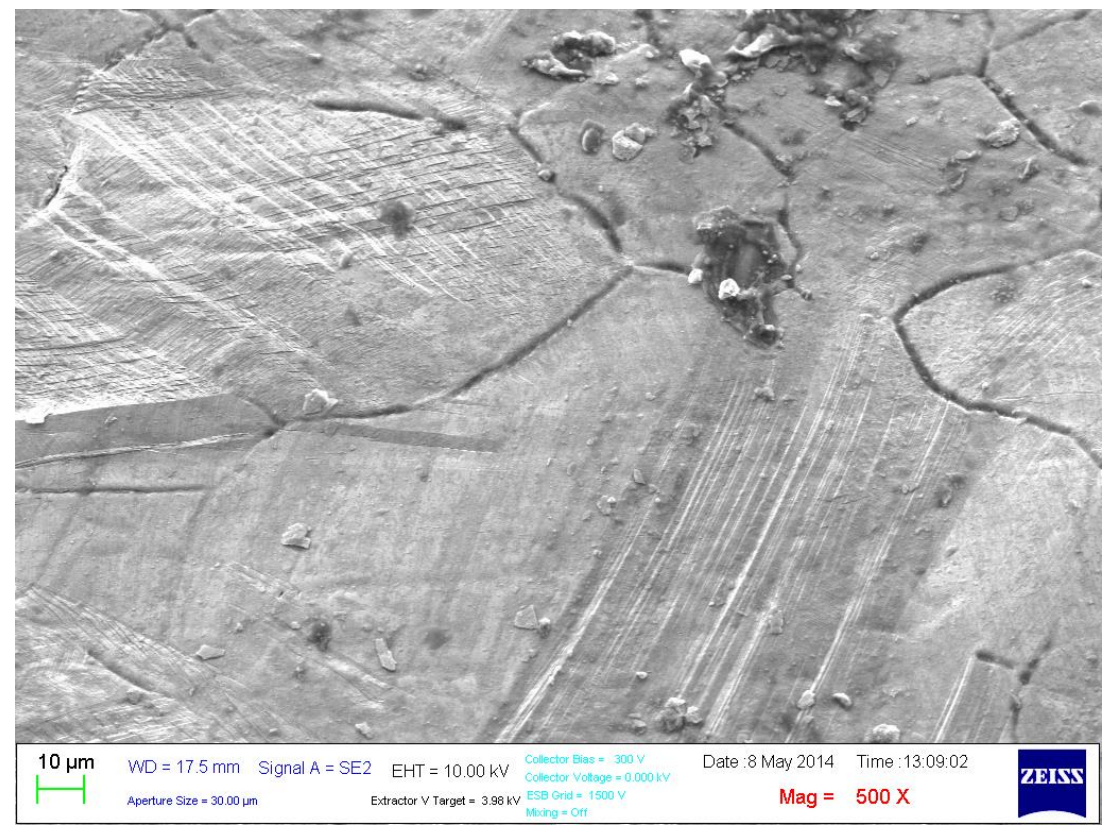

Figura 37 - Imagem de amostra tratada à $1250^{\circ} \mathrm{C}$ por 15 minutos apos ensaio de tração in situ.

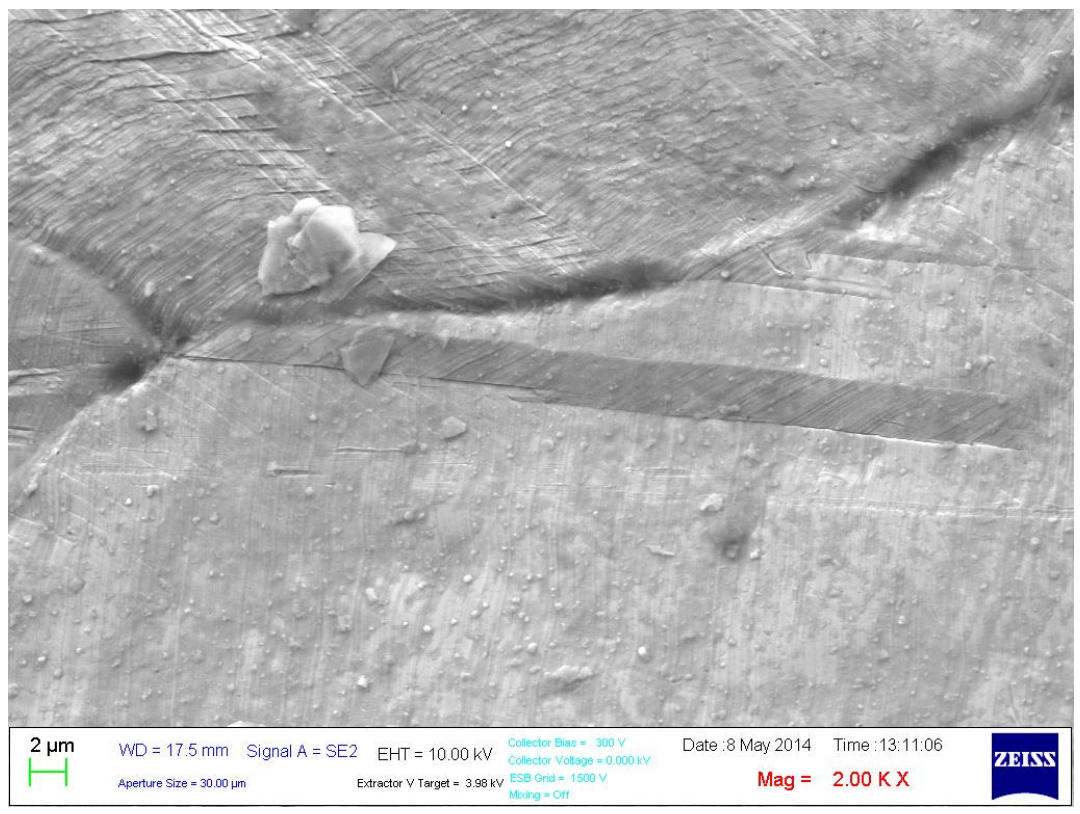

Figura 38 - Imagem de amostra tratada à $1250^{\circ} \mathrm{C}$ por 15 minutos apos ensaio de tração in situ.

As estrias criadas no material durante o ensaio de tração o que indica que a deformação ocorre através de deslocamento dos planos cristalinos. Não se verifica deslocamento entre cristais. 


\subsection{Metalografia}

A liga CoCr L605, além de ser uma liga muito difícil de revelar de forma que todos os limites entre grãos estejam visíveis, isso torna muito difícil medir o tamanho de grão com alto grau de precisão. Além disso, após o recozimento o material apresenta maclas, o que dificulta a contagem dos grãos, pois estas devem ser ignoradas ${ }^{40}$.

O material como recebido, após ser trefilado para atingir as dimensões necessárias para a manufatura do stent, apresenta um tamanho médio de grão entre 9 e 10 segundo a norma ASTM E112(Dados do Fabricante).

Os resultados dos ensaios metalográficos demonstraram que a temperatura de $1000^{\circ} \mathrm{C}$, o crescimento de grão é lento de forma que nas amostras tratadas por 4 e 7 minutos não se observa crescimento de grão, sendo que nas amostras tratadas por 10 e 15 minutos a $1000^{\circ} \mathrm{C}$, foi possível perceber algum crescimento de grão ainda que pequeno. Já as amostras tratadas a partir de $1175^{\circ} \mathrm{C}$ o tamanho de grão apresentou um crescimento muito expressivo partindo de grão ASTM 10 para grão ASTM 6 (Figura 39 a 50).

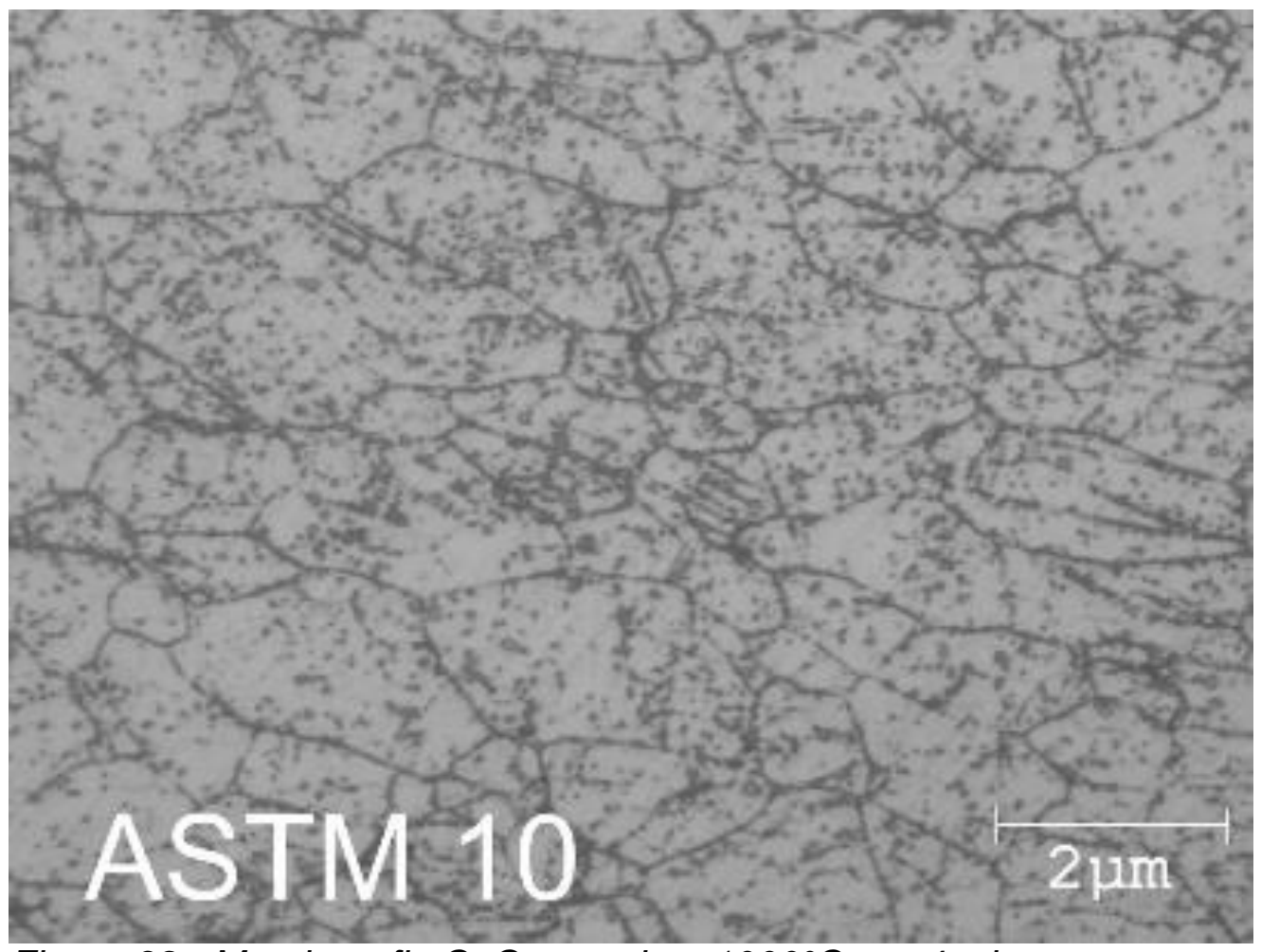

Figura 39 - Metalografia CoCr tratado a $1000^{\circ} \mathrm{C}$ por 4 minutos 


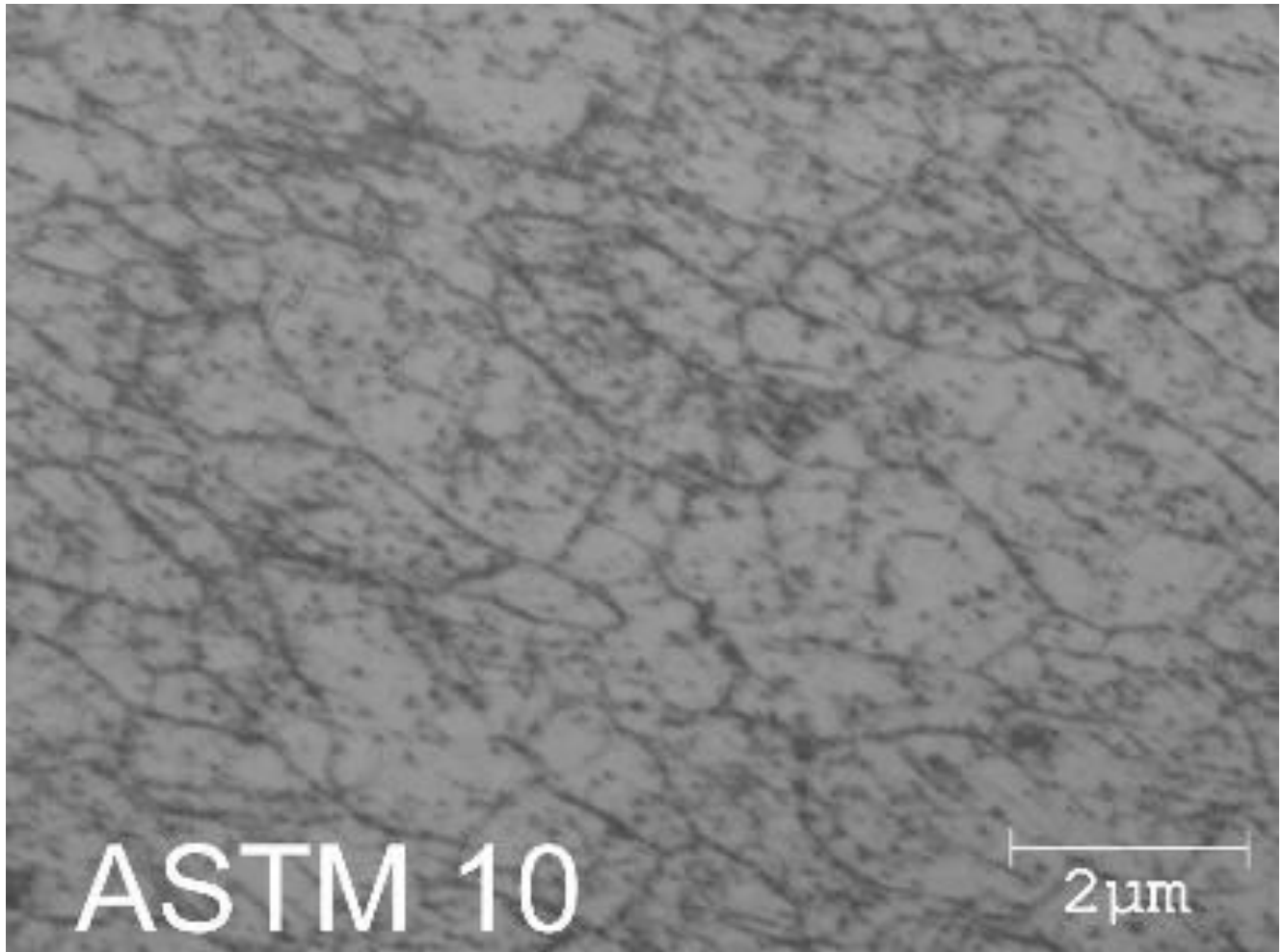

Figura 40 - Metalografia CoCr tratado a $1000^{\circ} \mathrm{C}$ por 7 minutos

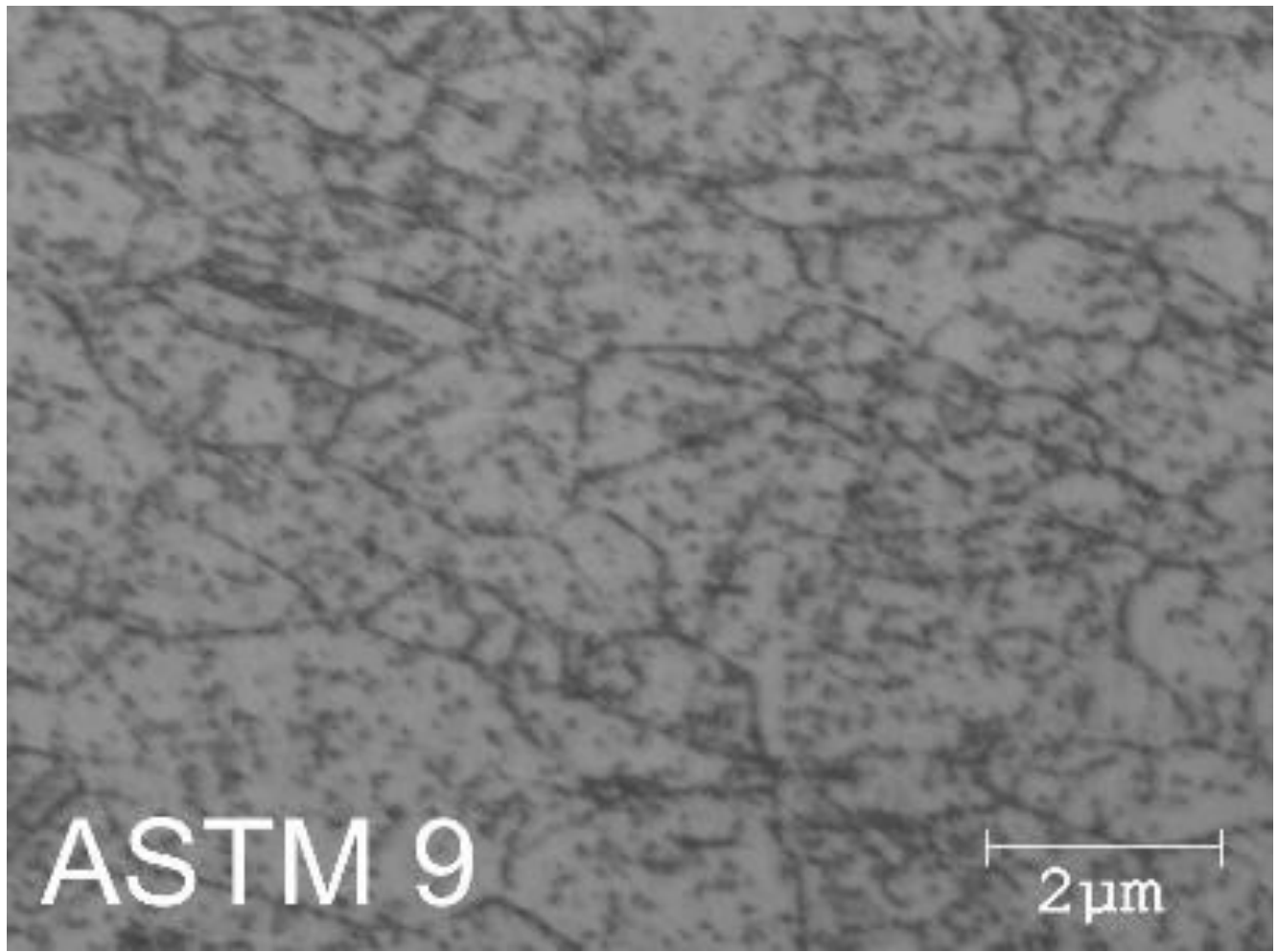

Figura 41 - Metalografia CoCr tratado a $1000^{\circ} \mathrm{C}$ por 10 minutos 


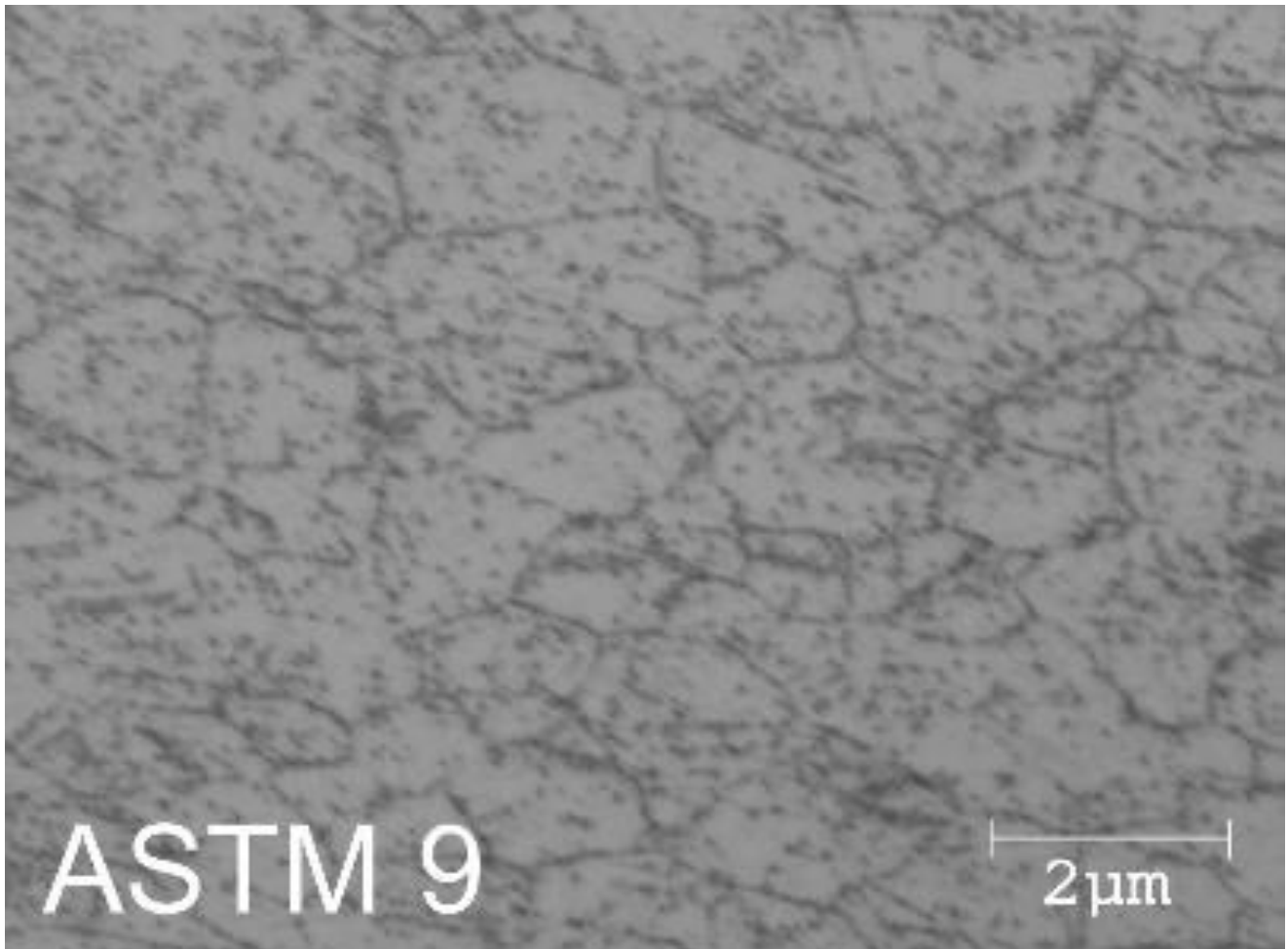

Figura 42 - Metalografia CoCr tratado a $1000^{\circ} \mathrm{C}$ por 15 minutos

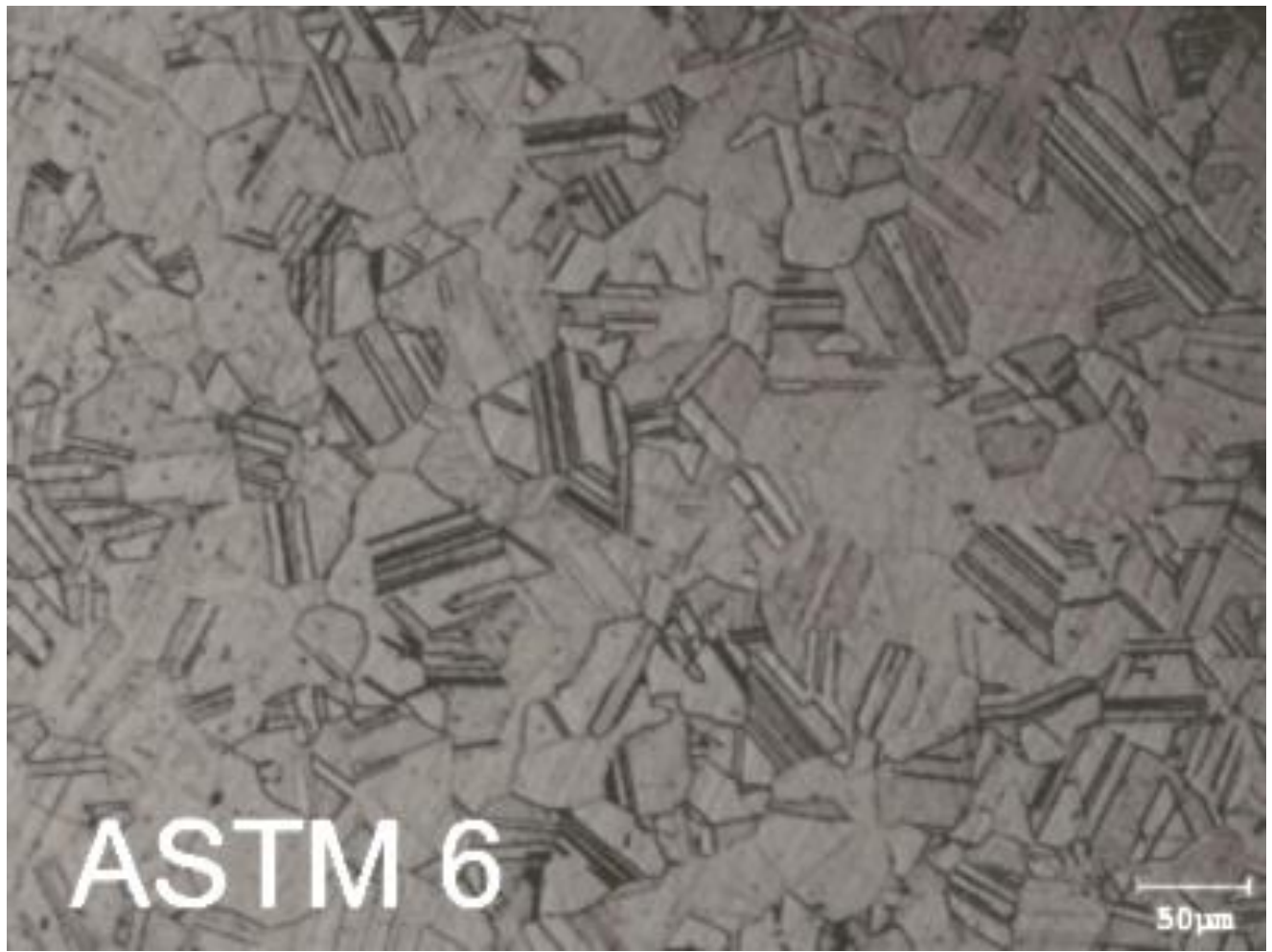

Figura 43 - Metalografia CoCr tratado a $1175^{\circ} \mathrm{C}$ por 4 minutos 


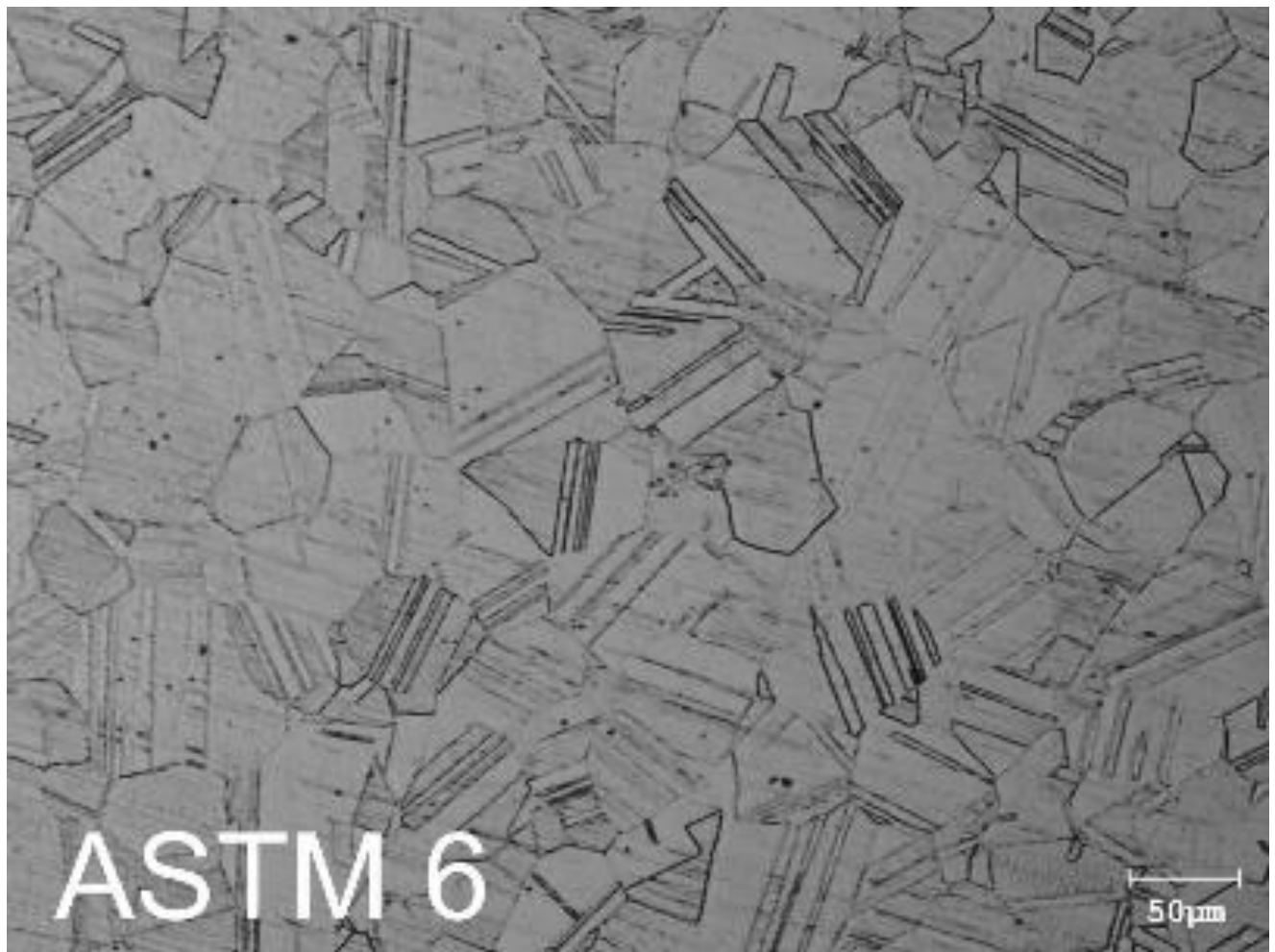

Figura 44- Metalografia CoCr tratado a $1175^{\circ} \mathrm{C}$ por 7 minutos

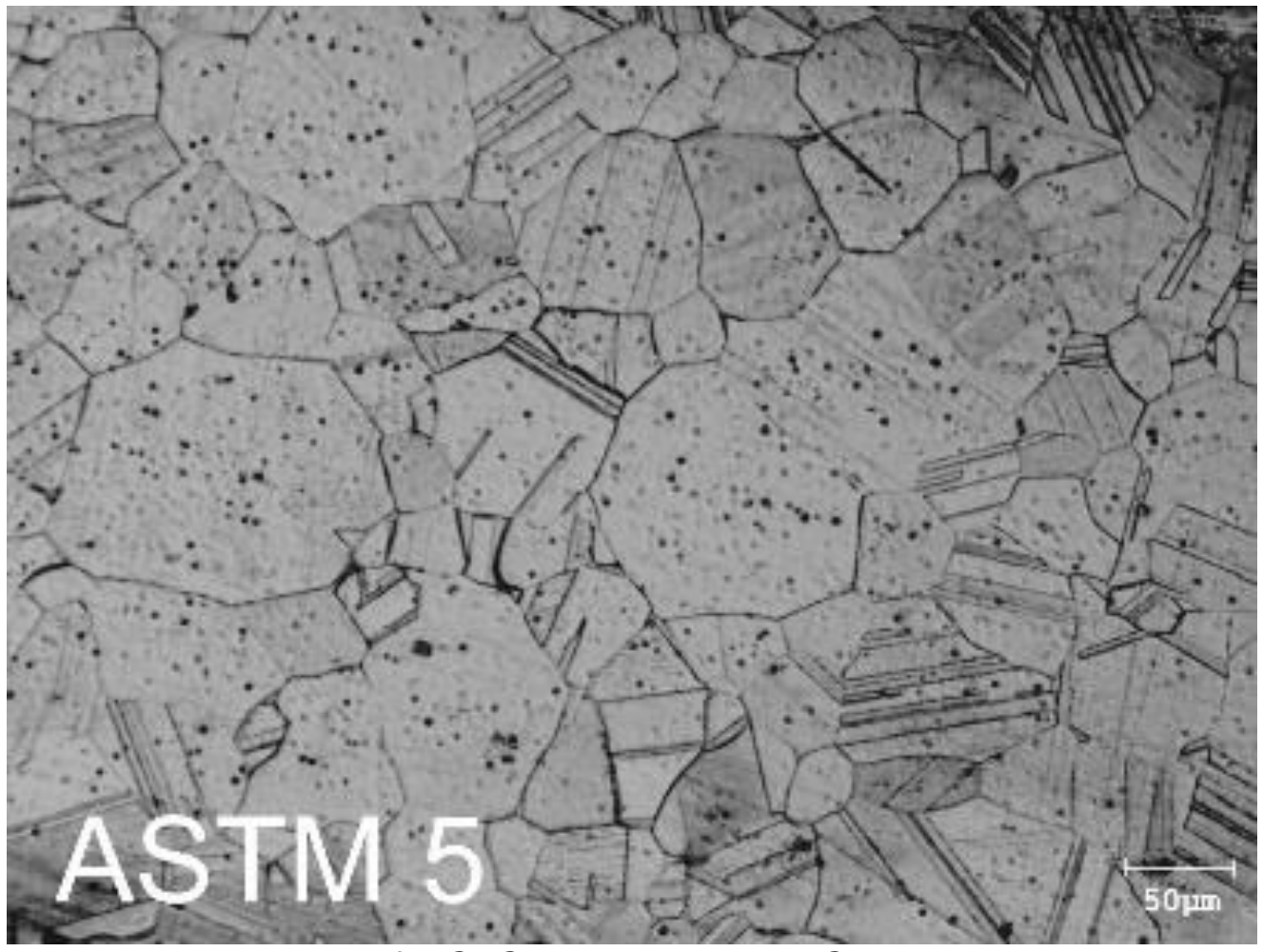

Figura 45 - Metalografia CoCr tratado a $1175^{\circ} \mathrm{C}$ por 10 minutos 


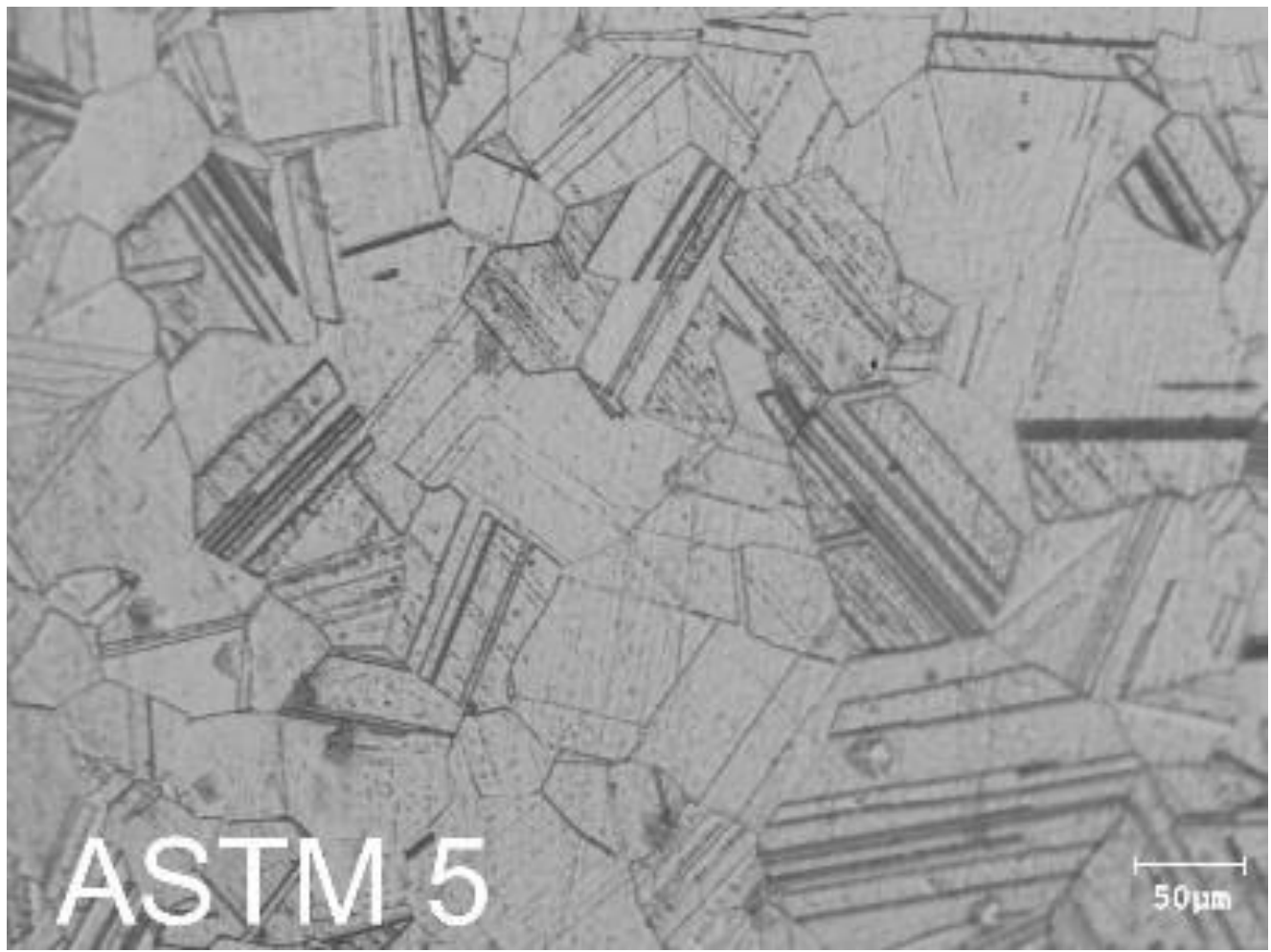

Figura 46 - Metalografia CoCr tratado a $1175^{\circ} \mathrm{C}$ por 15 minutos

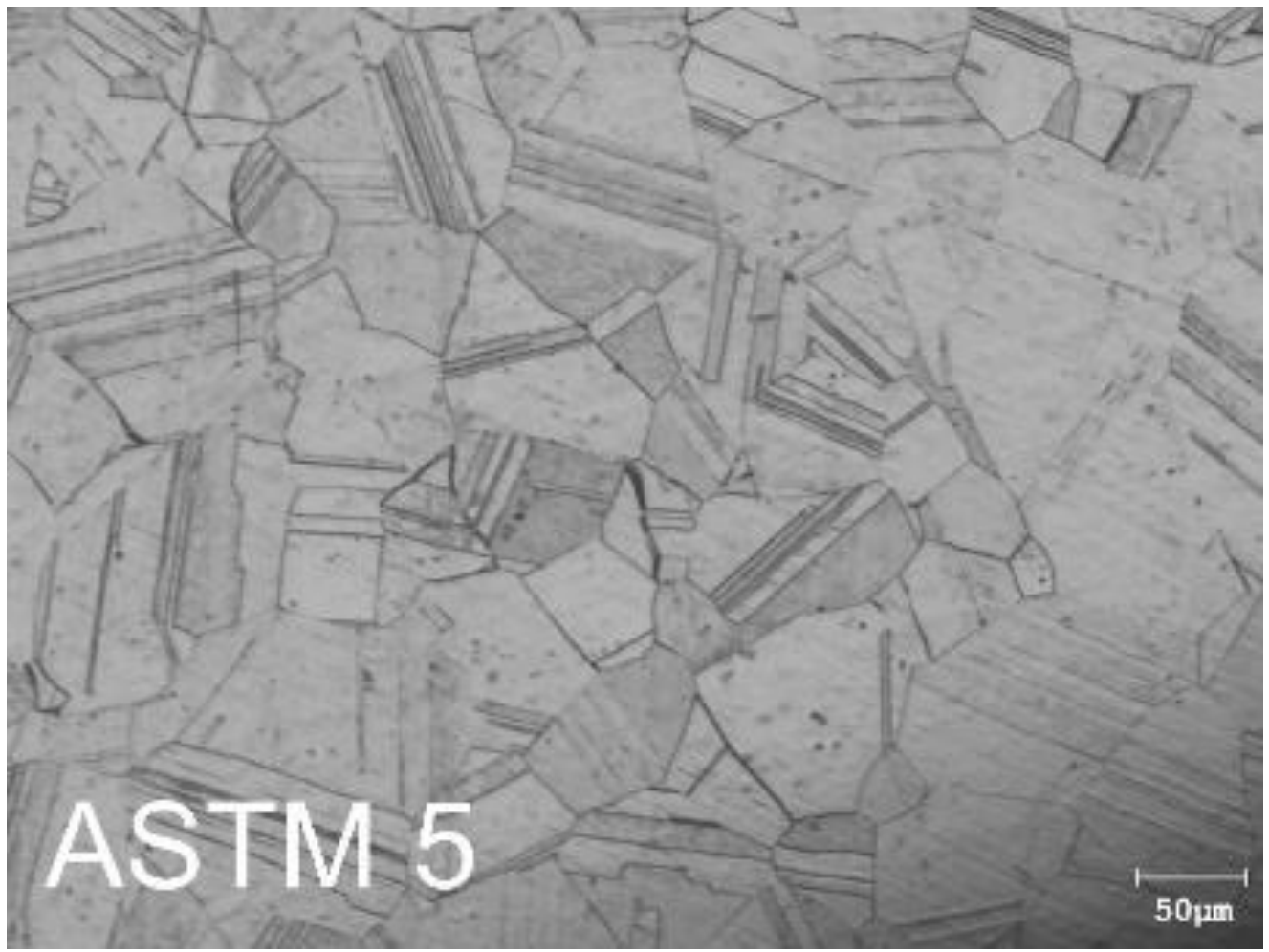

Figura 47 - Metalografia CoCr tratado a $1250^{\circ} \mathrm{C}$ por 4 minutos 


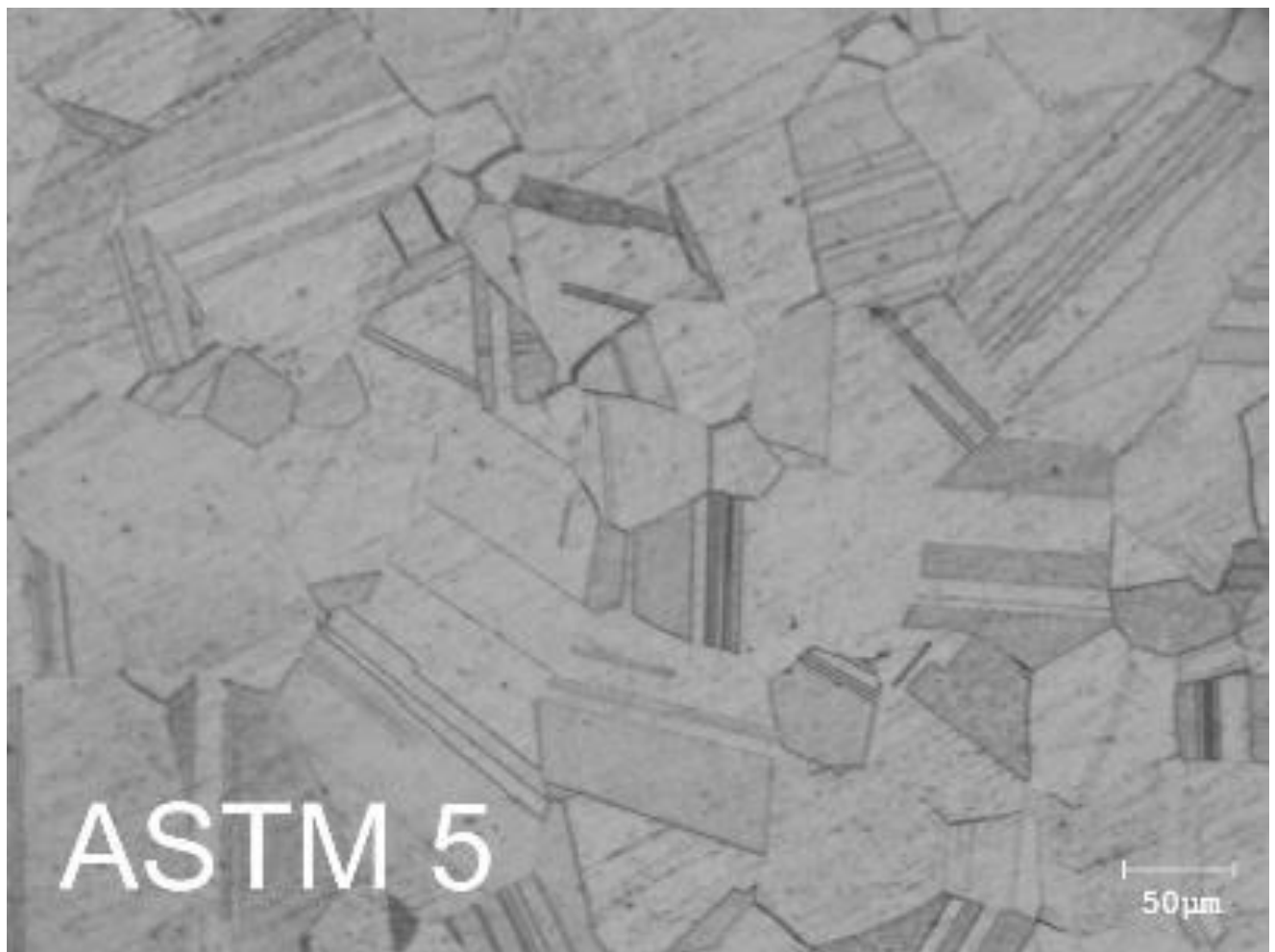

Figura 48 - Metalografia CoCr tratado a $1250^{\circ} \mathrm{C}$ por 7 minutos

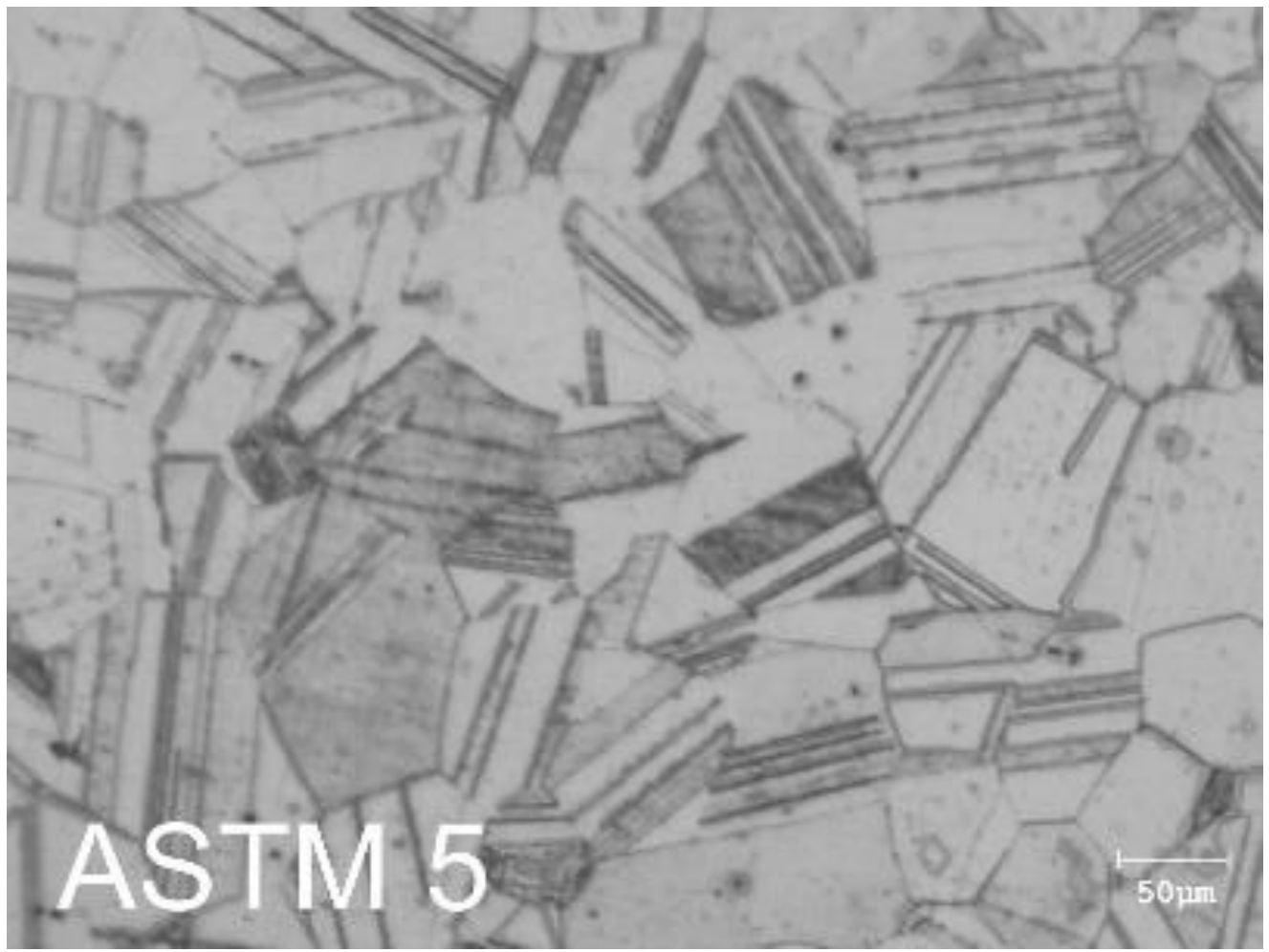

Figura 49 - Metalografia CoCr tratado a $1250^{\circ} \mathrm{C}$ por 10 minutos 


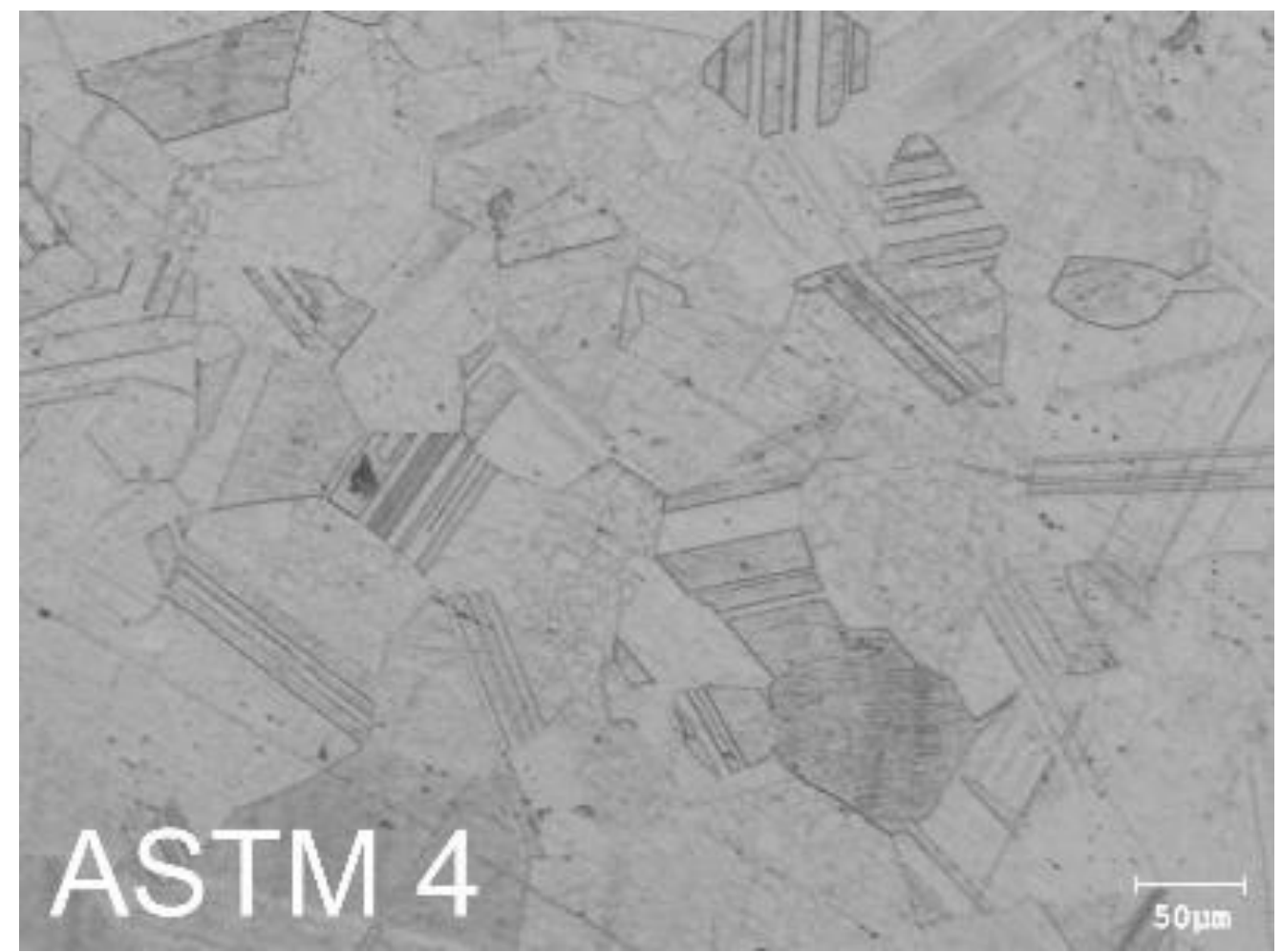

Figura 50 - Metalografia CoCr tratado a $1250^{\circ} \mathrm{C}$ por 15 minutos

\subsection{Microscopia eletrônica de varredura}

Uma amostra sem tratamento térmico foi preparada para microscopia eletrônica de varredura, a metodologia utilizada para a preparação da amostra é a mesma utilizada para amostras para metalografia, com a diferença, que não foi usado um fio para contato elétrico, mas sim foi feito um recobrimento por sputtering e não foi necessário revelar eletroquimicamente o material para a análise por MEV(Figura 51), a técnica de microscopia eletrônica de varredura possibilita não apenas visualizar os contornos de grão, mas também possibilita a identificação de fases cristalinas. 


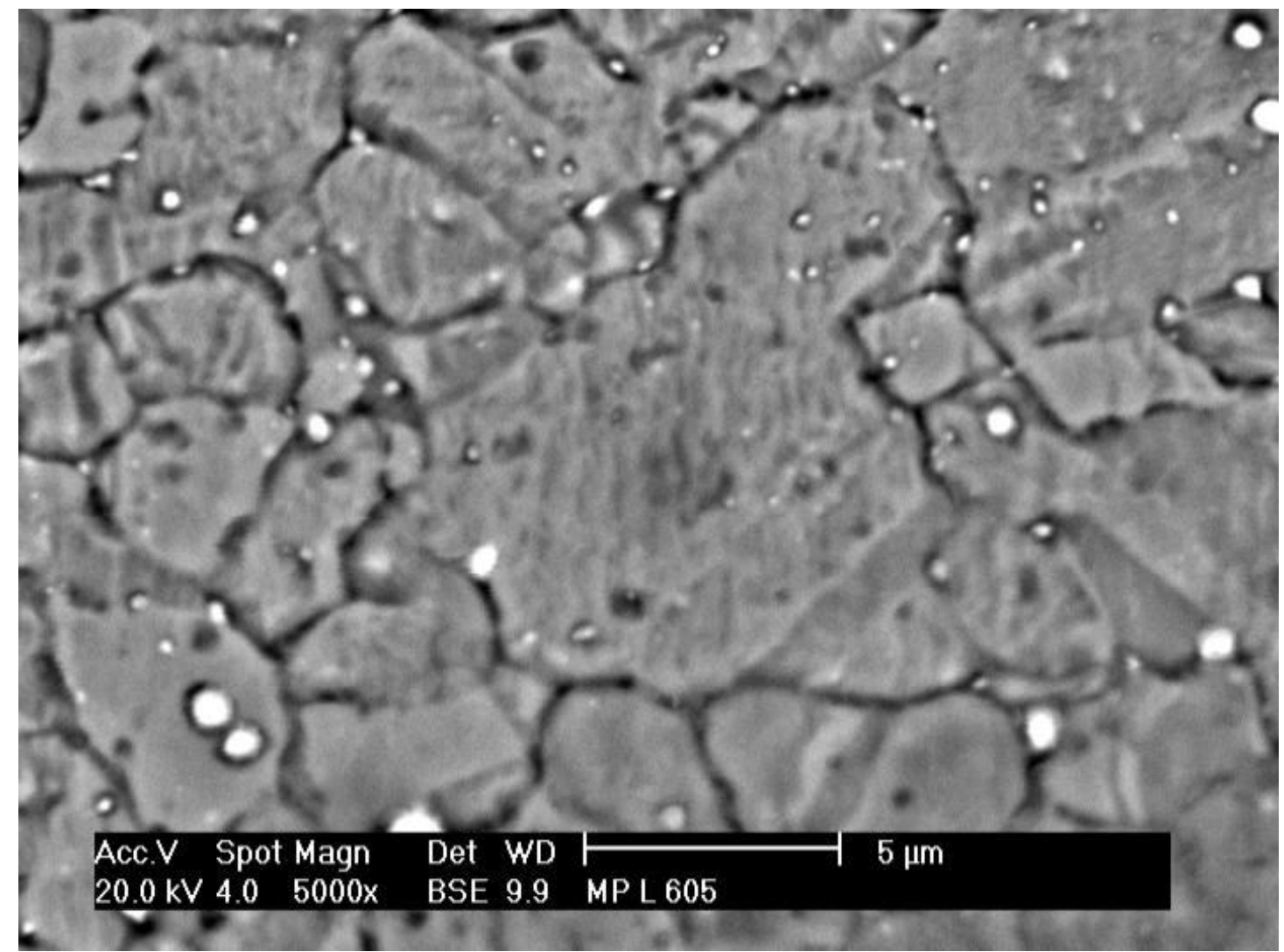

Figura 51- Imagem de amostra de CoCr L605 com precipitados.

Analisando a imagem obtida por elétrons retro espalhados é possível observar que a amostra apresenta duas fases distintas, uma delas mais predominante que aparece na imagem em tons de cinza, e a outra fase aparece em tons bem claros (branco) na forma de precipitados espalhados aleatoriamente na imagem.

É possível observar que o material sem tratamento térmico de recozimento, não apresenta as maclas que são notadas em amostras tratadas termicamente. Os precipitados que aparecem como pontos claros presentes em toda a amostra, foram analisados utilizando-se da técnica de EDX, o que permite comparar qualitativamente a composição química dos precipitados (pontos claros) com o restante do material (Figuras 52 e 53). 


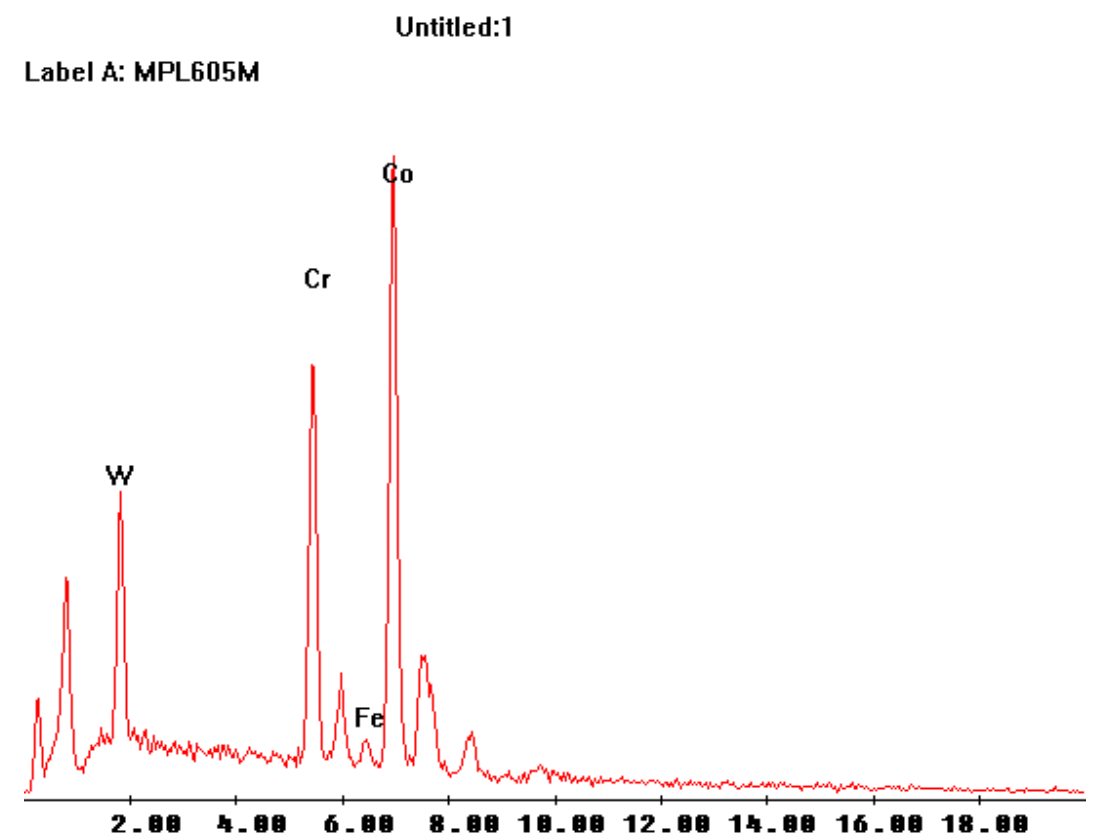

Figura 52 - EDX medido na parte cinza da imagem da figura 40

Analisando a fase da matriz da amostra por espectroscopia de raios $X$ (Figura 18) é possível observar-se uma grande concentração de cobalto e de cromo e tungstênio que são os principais componentes da liga, este dado é compatível com a composição química descrita na norma ASTM F90, além disso deve-se levar em consideração que a técnica não permite a identificação de elementos leves como carbono.

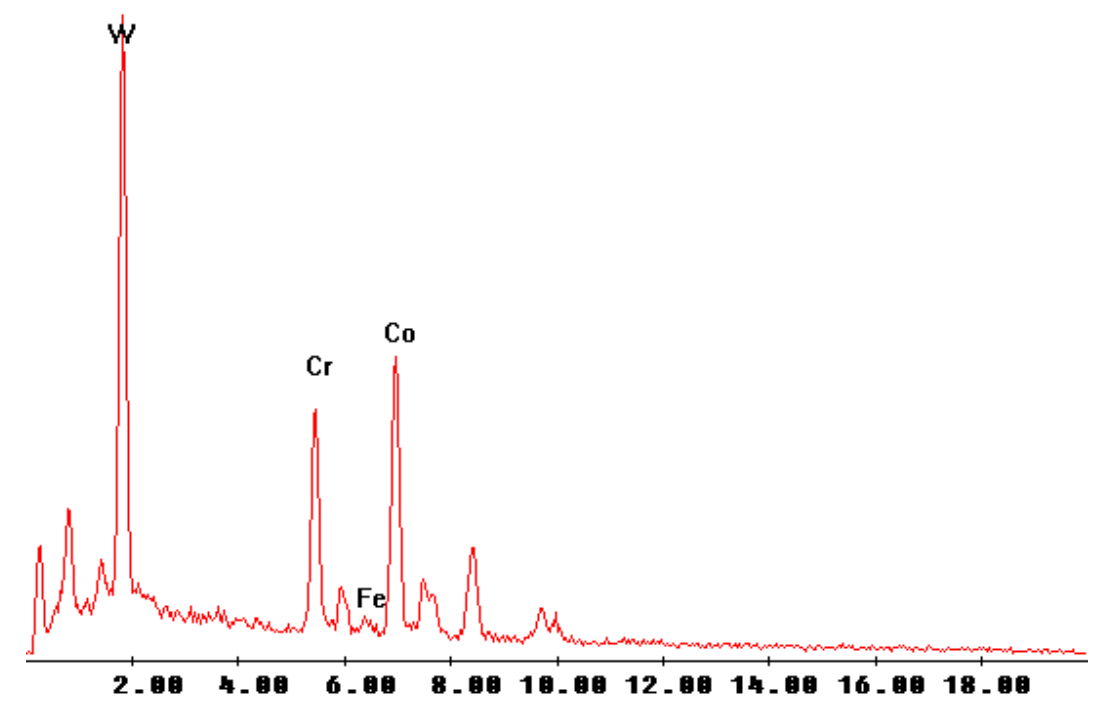

Figura 53 - EDX medido em um precipitado (ponto branco) da figura 40 
Ao analisar os pontos brancos pela mesma técnica (Figura 19), é possível observar que os sinais característicos de Cobalto e Cromo já não são os maiores, e o tungstênio aparece como o material mais predominante, este é um forte indicativo de que se tratam carbonetos de tungstênio.

\subsection{Microscopia eletrônica de transmissão (MET)}

Analisando-se as imagens obtidas por MET, devido ao grande aumento que é permitido por esta técnica, visualizam-se com detalhe os precipitados presentes na amostra. Os precipitados estão presentes em todo o material, ao menos no material bruto, não estando preferencialmente em contornos de grão; pelo contrário, estão uniformemente espalhados por todo o material.

Foram obtidas imagens com diferentes aumentos; nas micrografias eletrônicas da Figura 54 é possível visualizar-se vários precipitados presentes mesmo em aumentos consideráveis.

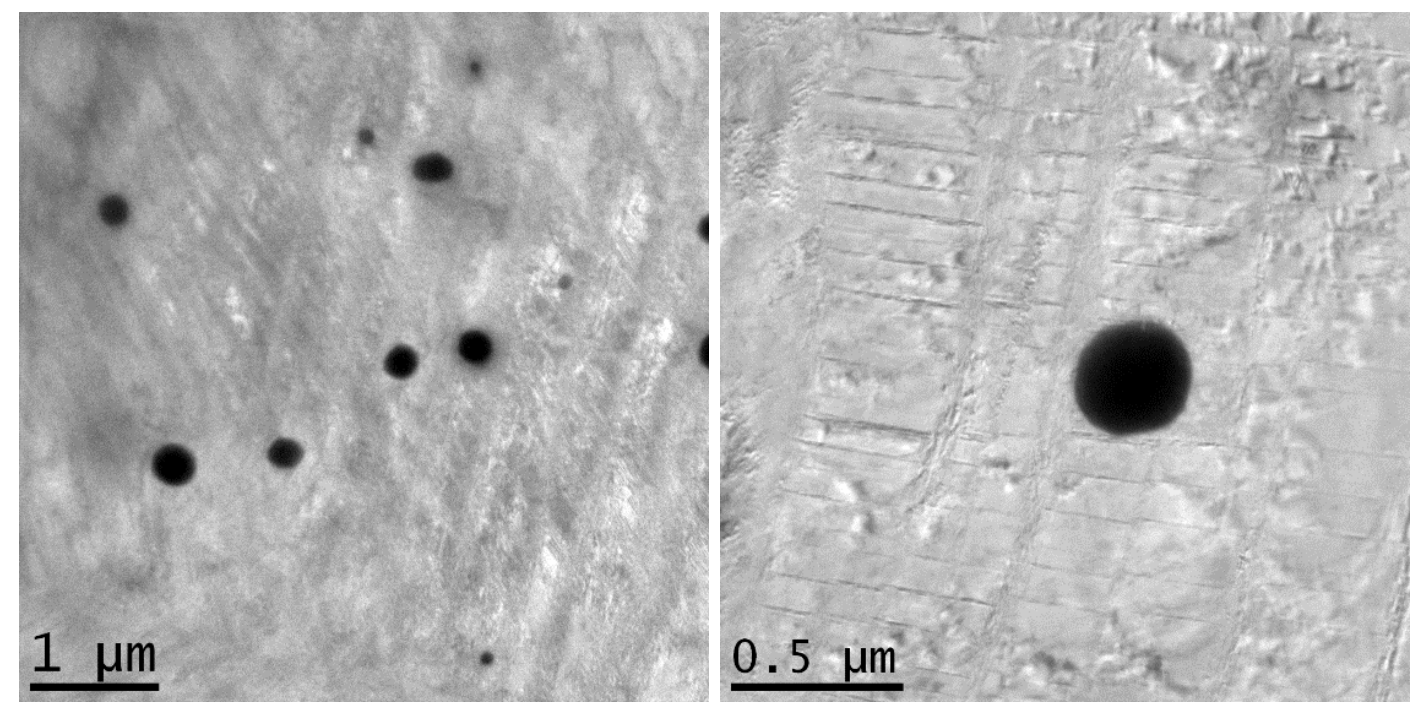

Figura 54 - Liga de CoCR L605 analisado no microscópio eletrônico de transmissão

É também possível observar-se muitas discordâncias presentes no material (Figura 55) o que é esperado, pois o material é trefilado, assim cria invariavelmente uma série de discordâncias em razão da severa deformação mec ânica aplicada. 


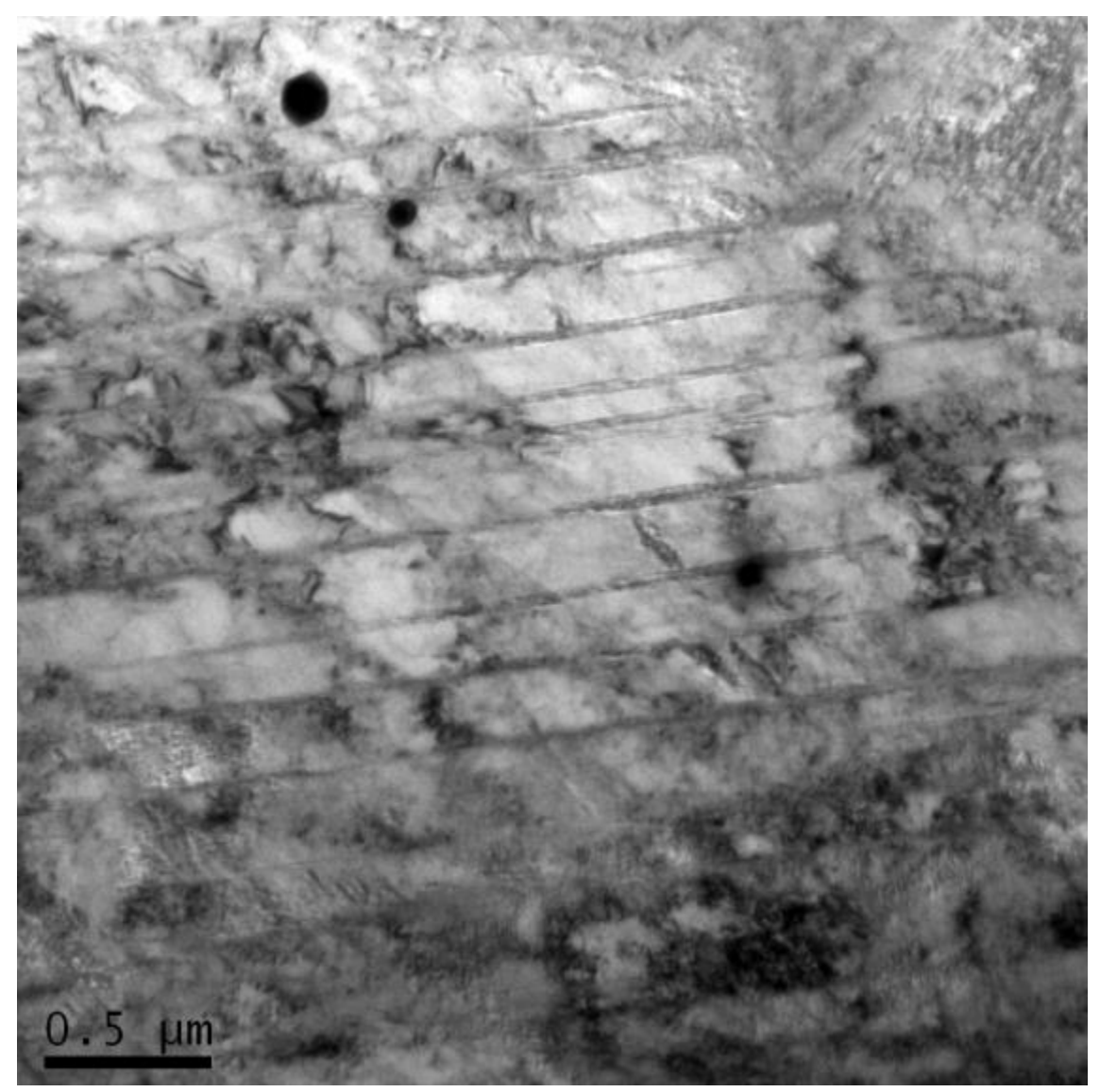

Figura 55 Liga de CoCR L605 microscopia eletrônica de transmissão

Os tamanhos dos precipitados de tungstênio presentes no material possuem uma grande variedade de dimensão $(0,025 \mu \mathrm{m}$ a $0,25 \mu \mathrm{m})$. Todos os precipitados presentes se aproximam de formas esféricas com poucas exceções as quais mostram algumas faces planas.

\subsection{Microscopia de Força Atômica}

Na mesma amostra eletropolida utilizou-se as técnicas de microscopia de força atômica e força elétrica simultaneamente. O equipamento permite que sejam geradas imagens de força atômica e força elétrica ao mesmo tempo, preservando assim a referência dimensional e de posição das imagens entre si (Figura 44).

As imagens das figuras 56 a 59, AFM KFM, foi gerada em uma região da amostra onde havia um grande precipitado encrustado e foi possível identificar que na região ao redor do precipitado forma-se uma depressão onde precisamente 
no centro do precipitado aparece como um pico acima do restante do material, demonstrando que o precipitado não sofre eletropolimento, mas concentra tensão ao seu redor aumentando a retirada de material o que forma o vale. A imagem de força elétrica permite visualizar o que ocorre durante o eletropolimento, na região ao redor do precipitado, pode-se observar uma região mais clara ao redor do precipitado, porém no precipitado o potencial elétrico é inexistente.

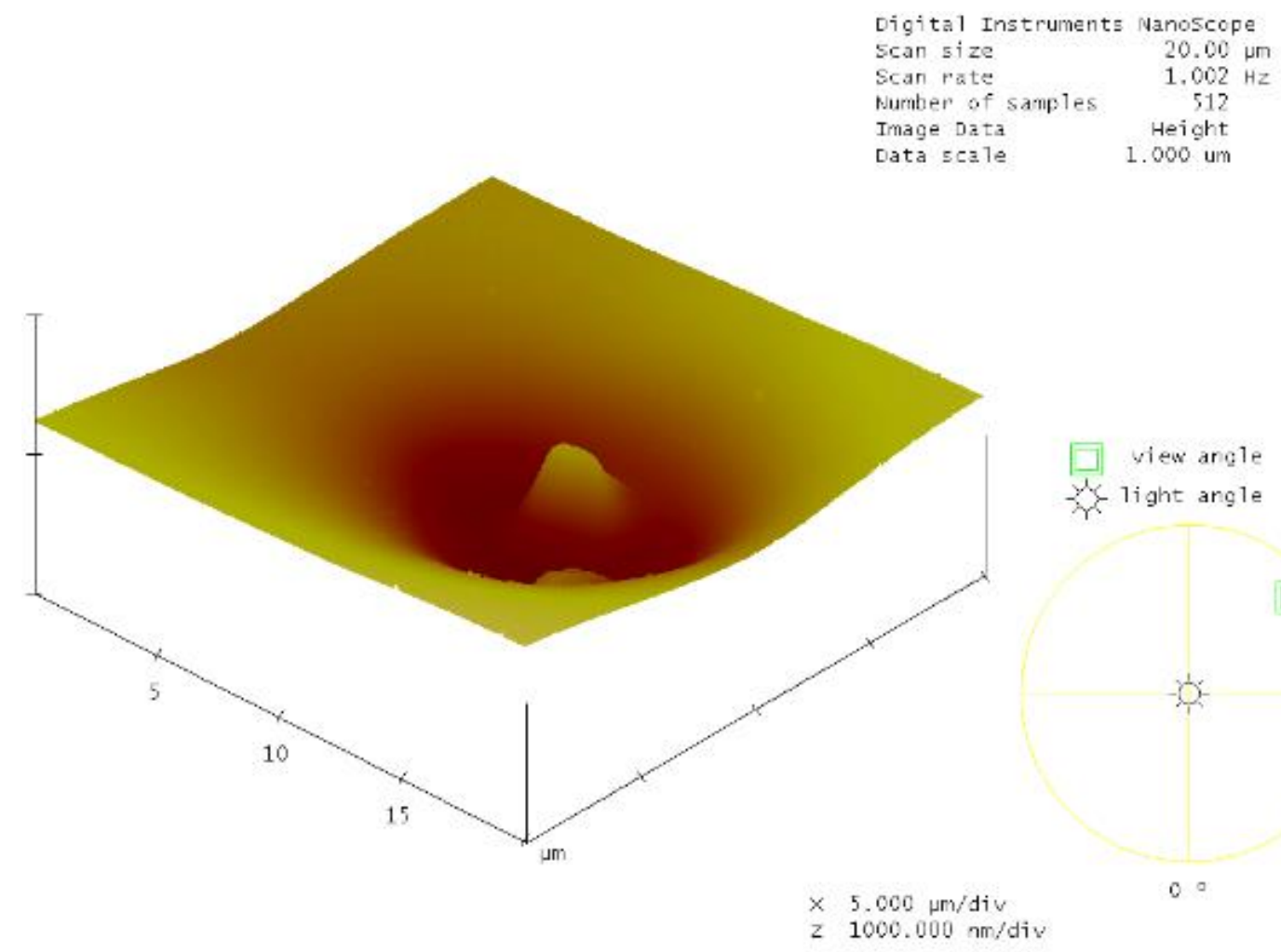

06151252.001

Figura 56 Imagem em perspectiva 3d de microscopia de força atômica 


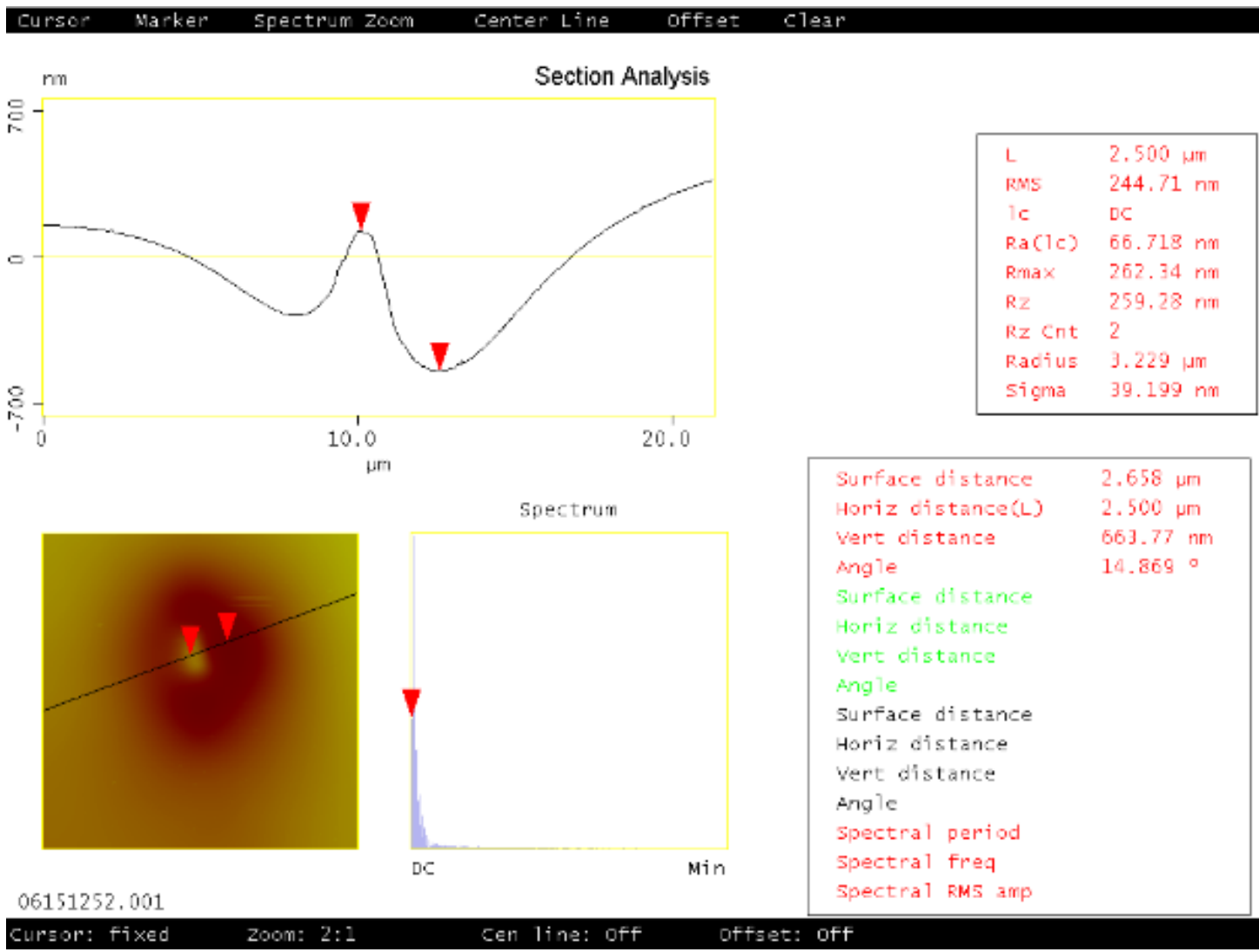

Figura 57 imagem em corte de microscopia de força atômica

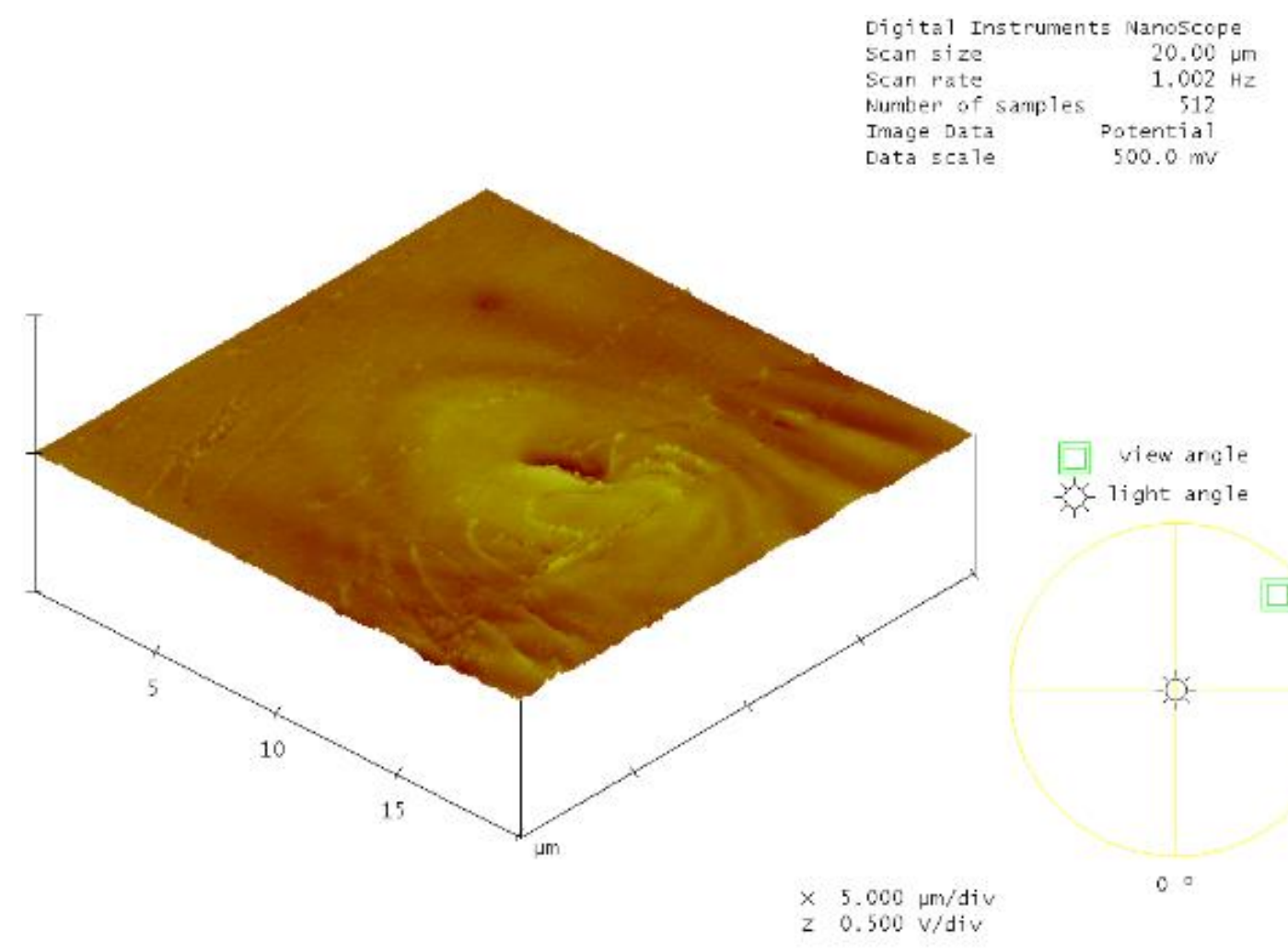

06151252.001

Figura 58 Imagem em perspectiva $3 d$ de microscopia de força elétrica 


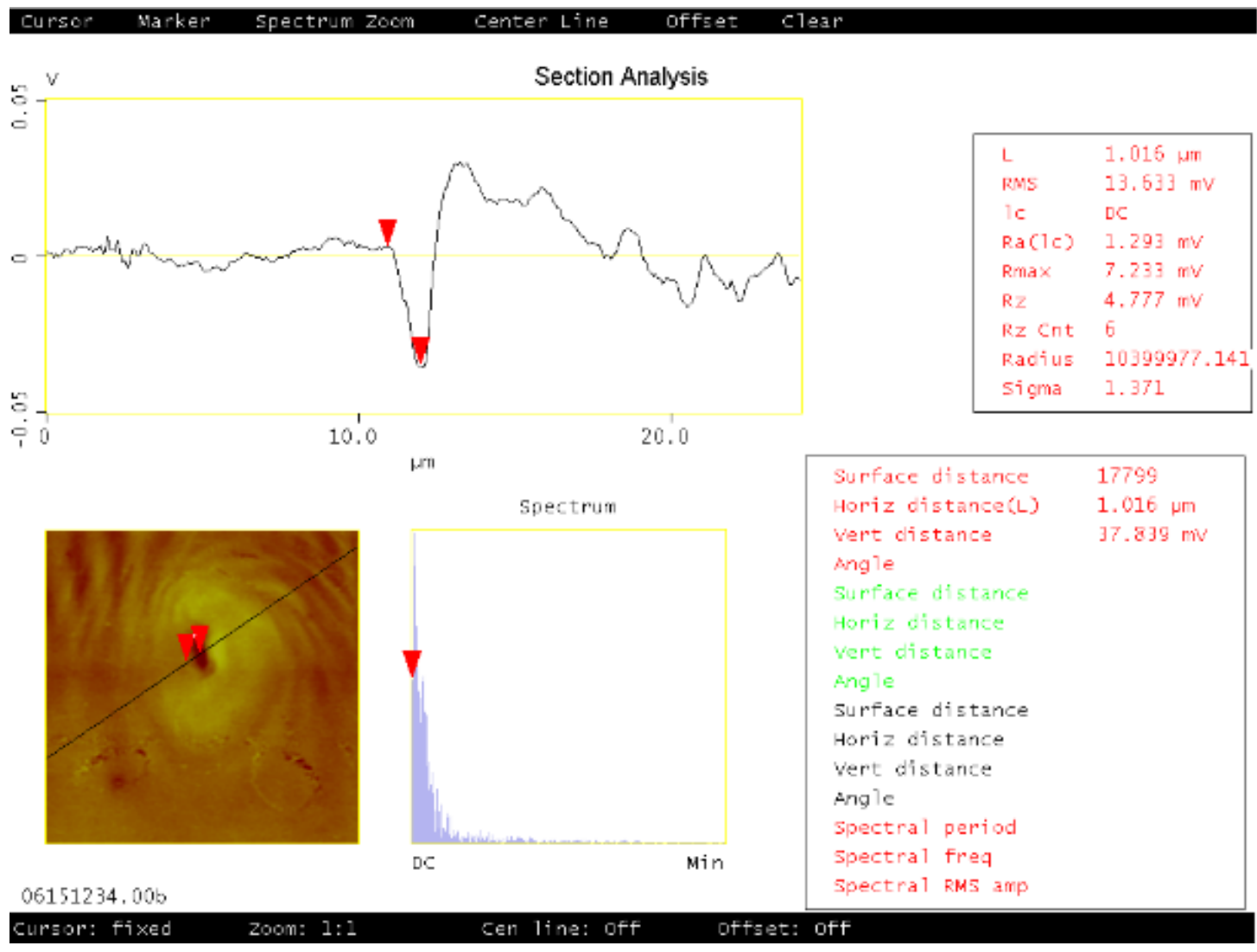

Figura 59 imagem em corte de microscopia de força elétrica 


\section{DISCUSSÃO}

O forno utilizado para o tratamento térmico das amostras, foi concebido especialmente para o tratamento térmico de stents que variam em comprimento de $9 \mathrm{~mm}$ até $38 \mathrm{~mm}$ de forma que a região em que a temperatura se mantem próxima à faixa de de $\pm 14^{\circ} \mathrm{C}$, é de apenas $60 \mathrm{~mm}$. Nos ensaios feitos pelo fabricante utilizouse de amostras com 200 milímetros de comprimento útil e um extensômetro no centro de $50 \mathrm{~mm}$, as amostras utilizadas no trabalho tem $70 \mathrm{~mm}$ e foram usados $40 \mathrm{~mm}$ de comprimento útil e não foi utilizado extensômetro, de forma que os ensaios de tração tiveram diferenças consideráveis de layout, no entanto, os resultados foram idênticos com exceção do limite de escoamento.

Os ensaios de tração in situ foram realizados com amostras de comprimento útil ainda menor $(26,3 \mathrm{~mm})$, no entanto os resultados de módulo de elasticidade e limite de escoamento foram muito próximos dos resultados obtidos nos ensaios de tração de amostras com o mesmo tratamento térmico. Infelizmente a amostra escorregou na fixação antes que rompesse perdendo-se assim os resultados de deformação e tensão máximos.

Os resultados de metalografia mostraram que as amostras tratadas a $1000^{\circ} \mathrm{C}$ apresentaram pouco crescimento de grãos de forma que o índice ASTM não diferenciou os tratamentos de 4 e 7 minutos do material como recebido, e os tratamentos por 10 e 15 minutos apresentaram pequeno crescimento variando 0 índice ASTM de 10 para 9. No entanto houve uma mudança significativa no comportamento mecânico do material, sendo que sem tratamento térmico a tensão máxima atingiu $1600 \mathrm{MPa}$ enquanto as amostras tratadas a $1000^{\circ} \mathrm{C}$ fraturaram antes de atingir $1300 \mathrm{MPa}$. Isto indica que as tensões residuais originadas no processo de trefilação durante fabricação do tubo foram aliviadas pelo tratamento térmico que embora não tenha provocado efeito notável na microestrutura, causou uma redução da resistência à fratura de $20 \%$. Resultado semelhante foi notado nos dados de limite de escoamento, onde o material sem tratamento era de 1170Mpa e caiu para $770 \mathrm{MPa}$ no material tratado a $1000^{\circ} \mathrm{C}$, e a ductilidade que inicialmente era de $17 \%$ passou para valores acima de $50 \%$ em todas as amostras. Houve pouca variação dos resultados mecânicos entre todas as amostras tratadas a $1000^{\circ} \mathrm{C}$.

Os tratamentos com temperatura de $1175^{\circ} \mathrm{C}$, resultaram em aumento significativo nos tamanhos de grão, indo de ASTM 10 do material original que 


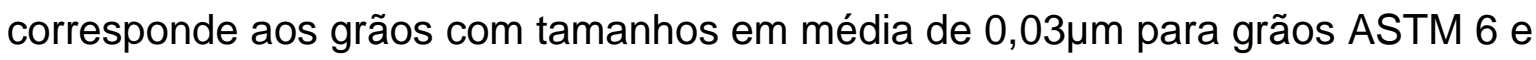
5 cujos grãos tem em média 5 e $10 \mu \mathrm{m}$, respectivamente, ou seja, muitas vezes maior enquanto que as propriedades mecânicas sofreram alterações significativas e mostraram forte tendência de queda cada vez em que se aumentava o tempo de tratamento térmico.

Um dos fatores que explicam a relação de tamanho de grão com a tensão de escoamento é o fato de o material deformar por escorregamento de planos como indica as estrias no ensaio de tração in situ e possuir grãos menores resulta em uma quantidade maior de planos que agem como obstáculos entre sí aumentando o limite de escoamento.

A espessura reduzida do material quando próxima do tamanho de grão corresponde também a uma redução de planos de escorregamento e consequentemente a interferência entre os planos ${ }^{41}$, fazendo com que nestes casos o estado de encruamento seja influenciado pela relação de tamanho entre o grão da microestrutura e a espessura do material ${ }^{42}$.

Os tratamentos com temperaturas de $1250^{\circ} \mathrm{C}$ resultaram em uma rápida perda de propriedades mecânicas situando-se próximo de $50 \%$ dos valores originais do material já com o tempo de tratamento térmico de 4 minutos(Figura 60 e 61). No entanto para tratamentos com maior duração a tensão máxima do material e o limite de escoamento mostraram uma convergência com relação aos tratamentos térmicos a $1175^{\circ} \mathrm{C}$.

O limite de escoamento combinado é o dado mais importante do material para a aplicação como stent. O módulo de elasticidade se mantem estavel pois é intrinseco ao material. O limite de escoamento mostrou-se bastante sensível aos tratamentos inclusive os de menor temperatura $\left(1000^{\circ} \mathrm{C}\right)$. Para a aplicação como stent, não é interessante que o material se comporte como uma mola, pois em dois momentos importantes este deve ser deformado mecanicamente e deve manter a forma imposta. O primeiro é no momento da crimpagem, onde o stent é pressionado radialmente contra um balão expansível, e se neste momento o stent apresentar um comportamento elástico este se solta do balão, assim que a força do equipamento de crimpagem for interrompida, pois recupera em parte seu diâmetro anterior. O segundo momento, este muito mais crítico é na colocação do stent na coronária do paciente, onde o sistema cateter-balão-stent é posicionado no local da obstrução e o balão é inflado até pressionar o stent contra as paredes da artéria. 
O balão é desinflado e o stent deverá se manter pressionando a artéria e se neste momento tiver um comportamento elástico ele pode se soltar e se movimentar.

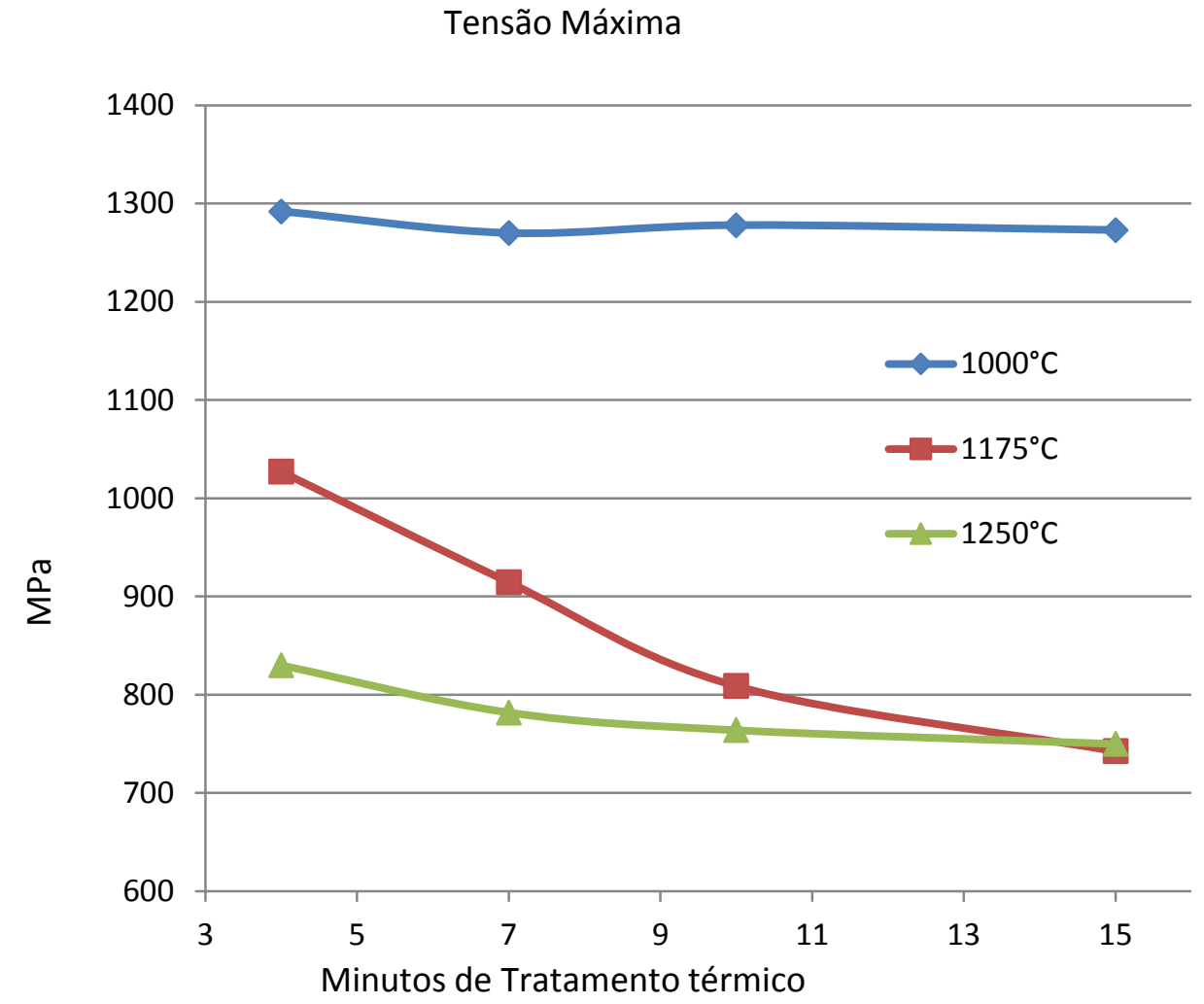

Figura 60 - Comparação entre resultados de tensão máxima

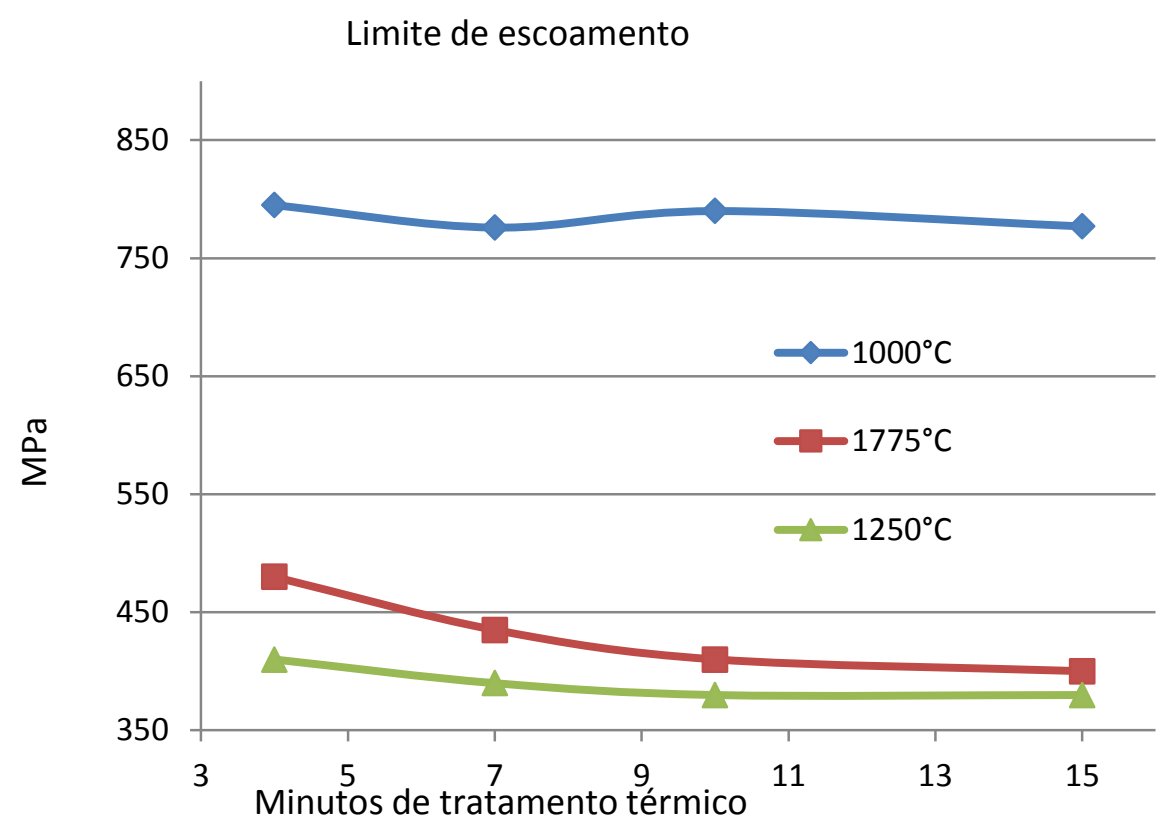

Figura 61 - Comparação entre limites de escoamento 
Por outro lado, se o stent tiver um limite de escoamento muito baixo, suas estruturas devem ser maiores para compensar a resistência do material, ou este terá força radial insuficiente para segurar as paredes da artéria e uma vez colocado, a artéria pode vencer a força radial do stent voltando a obstruir a passagem do sangue.

A ductilidade de todas as amostras após todos os tratamentos térmicos se mostraram superiores à do material como fornecido, e isto era esperado pois o material é fornecido encruado. Os tratamentos térmicos às temperaturas de $1000^{\circ} \mathrm{C}$ tiveram melhores resultados de ductilidade enquanto os tratamentos a temperaturas de $1250^{\circ} \mathrm{C}$ tiveram os piores. No entanto todos os testes resultaram em ductilidade acima de $30 \%$ o que é suficiente para a aplicação.

Além do comportamento mecânico, outro fator que pode prejudicar o desempenho do stent é a presença de precipitados de tungstênio, estes precipitados prejudicam o eletro-polimento, impedindo que a peça fique totalmente lisa após o mesmo, criando pontos com depressões e diferença de potencial elétrico nas regiões adjacentes. Estas diferenças de topografia e principalmente de carga elétrica, podem prejudicar o desempenho do implante, uma vez que a existência de pontos onde existem diferenças de potencial é maior a probabilidade de ocorrer corrosão e as depressões podem acumular material indesejado, o que pode prejudicar o desempenho biocompatível do stent.

Os tratamentos térmicos mais longos e com temperaturas a partir de $1175^{\circ} \mathrm{C}$ são efetivos para a dissolução dos precipitados ${ }^{43}$, mas as propriedades mecânicas que são características chave do material caem para valores comparáveis a materiais mais comuns como aço inox $316 \mathrm{~L}$, por exemplo. A presença dos precipitados está ligada à alta ductilidade do material| ${ }^{44}$, e caso os grãos fiquem muito grandes o stent fica suscetível à quebra, o que pode gerar calcificação ${ }^{45}$ e consequente estreitamento da artériado paciente.

Os tratamentos com temperatura de $1250^{\circ} \mathrm{C}$, provocaram crescimento excessivo das estruturas cristalinas que compõem de grão, de forma que em um stent, o tamanho de grão chega a dimensões próximas as dimensões das estruturas, esta não é uma combinação boa, pois tanto em caso de sobrecarga quanto em condições de fadiga, a probabilidade da estrutura se romper é muito 
maior do que no caso de estrutura com tamanho de grão menor, pois uma eventual trinca poderia se propagar sem obstaculos.

No que diz respeito a precipitados, acima de $1175^{\circ} \mathrm{C}$ os precipitados começam a ser dissolvidos, de forma que nas amostras tratadas a $1000^{\circ} \mathrm{C}$, apesar de existirem condições mecânicas excelentes, o eletropolimento é prejudicado pelos precipitados de tungstênio que fazem com que o stent apresente uma superfície repleta de pontos brancos o que não é aceitável do ponto de vista comercial. Portanto apesar de apresentar os melhores resultados mecânicos todos os tratamentos térmicos a $1000^{\circ} \mathrm{C}$ são descartados para a aplicação como stent.

No tratamento térmico a $1175^{\circ} \mathrm{C}$ conseguiu-se a melhor combinação de dissolução de precipitados e comportamento mecânico, especialmente o tratamento por 4 minutos mostrou a melhor combinação de resultados.

O material não sofre transformações de fase entre a temperatura ambiente e a fusão da liga, portanto a têmpera não tem o mesmo efeito que é conseguido com aço carbono por exemplo, quando se deseja um material mais duro, de forma que as intervenções que são possíveis de serem feitas no material são o envelhecimento a temperaturas em torno de $800^{\circ} \mathrm{C}$ e o trabalho a frio.

Nenhuma dessas técnicas são aplicáveis neste estudo porque o tubo já possui paredes finas $(0,1 \mathrm{~mm})$ e o produto final (stent) tem espessura não maiores do que $0,075 \mathrm{~mm}$ ou seja, mesmo que fosse possível trabalhar a frio, este eliminaria a possibilidade de obter um stent a partir do tubo em questão.

A alternativa de envelhecimento, apesar de demonstrado na literatura que endurece o material, a literatura também indica que este endurecimento se dá pela precipitação de carbonetos e estes carbonetos não são desejados por prejudicarem o eletropolimento do material. Foi feito uma experiência de envelhecimento a $860^{\circ} \mathrm{C}$ por uma hora, porem o resultado pouco divergiu do material que não passou pelo mesmo processo. Existe uma última alternativa que seria o resfriamento rápido após o tratamento térmico, e foi feita uma tentativa, e o resultado foi um aumento perceptível do limite de escoamento porém pouco expressivo e insuficiente para as especificações.

Os tratamentos térmicos inferiores a $1175^{\circ} \mathrm{C}$ apresentam ótimas propriedades mecânicas e relativa facilidade para controla-las, porém a estas temperaturas os precipitados não são reduzidos. 
A temperaturas mais altas, $1175^{\circ} \mathrm{C}$ e $1250^{\circ} \mathrm{C}$ e períodos curtos $(4$ e 7 minutos) as propriedades mecânicas ainda são razoáveis e tem-se uma remoção importante dos precipitados no caso de $1175^{\circ} \mathrm{C}$ e completa no caso de $1250^{\circ} \mathrm{C}$, e em períodos mais longos (10 e 15 minutos) os valores de limite de escoamento caem para valores próximos de $400 \mathrm{MPa}$ ambos com ausência de precipitados.

Não foi possível ainda traçar uma equivalência entre o tamanho de grão(Número ASTM), e as propriedades mecânicas, pois a equivalência se mostrou frágil na medida em que outros fatores como trabalho a frio e presença e concentração de precipitados influenciam no comportamento mecânico.

\section{CONCLUSÕES}

A única alternativa viável para modificar características mecânicas do stent ou do tubo, é o tratamento térmico. Quando a intenção do tratamento térmico é além de aliviar as tenções reduzir ou eliminar precipitados, o tratamento térmico necessário não pode ser feito em temperaturas iguais ou inferiores a $1000^{\circ} \mathrm{C}$, pois a estas temperaturas não há ainda solubilização do material, e o tratamento ocorre temperaturas mais próximas à de fusão o que compromete o desempenho mecânico do stent.

O ideal, é que o material seja fornecido já com poucos ou sem precipitados, pois com o material nestas condições é possível fazer um tratamento térmico entre $1000^{\circ} \mathrm{C}$ e $1150^{\circ} \mathrm{C}$ o que permite grande controle sobre as características mecânicas do material. 


\title{
REFERENCIAS BIBLIOGRÁFICAS
}

\begin{abstract}
${ }^{1}$ INDIANA HISTORICAL SOCIETY STAFF, Disponível em< http://www.indianahistory.org/our-collections/reference/notable-hoosiers/elwoodhaynes $>$ acessado em outubro de 2013
\end{abstract}

2 R. DAVIS. ASM Speciality Handbook, Nickel, Cobalt, and Their Alloys. ASM International, Pg 346 december 2000

${ }^{3}$ H-Liacy, A. Ablouali, M. Akbari-Garakani, Faliure analysis of a repaired gas turbine nozzle, Engineer Faliure Analysis 18 (2011) - 510-516

${ }^{4}$ W.H. Jiang, X.D. YAO, H.R. Guan, Z.Q. Hu, Secondary Carbide Precipitation in a directionaly Solidified Cobalt-Base Superalloy, Metalurgical and Materials Transactions A volume 30A, China - Marh 1999 513-520

${ }^{5}$ B.V. Cockeram, Developmento od wear-resistant coatings for cobalto vase alloys, West Miffin - PA USA, Surface and Coatings Technology 120-121 (1999) 509-518

${ }^{6}$ A.H. Fleitman, R.B. Herchenroeder, J.G.Y. Chow, cobalto-Base for Use in Nuclear Reactors, North Holland, Nuclear Engineering and Design 15 (1971) 345-362

${ }^{7}$ HAHN, SOOKAP. Os papéis da ciência dos materiais e da engenharia para uma sociedade sustentável. Palo Alto, Universidade de Stanford. 1994, vol.8, n.20 [cited 2011-08-18],pp. 36-42 .

${ }^{8}$ HALLIE E. PLACKO; Stanley A. Brown; Joe H. Payer. Effects os Microstructure on the Corrosion Behavior of CoCr Porous on Orthopedic Implants, Cleveland, 1998 John Wiley \& Sons, Inc

9 MUNEHIRO, OGAWA; YASUAKI, TOHMA; HAJIME, OHGUSHI; YOSHINORI, TAKAKURA AND YASUHITO, TANAKA: Early Fixation of Cobalt-Chromium Based Alloy Surgical Implants to Bone Using a Tissue-engineering Approach, Nara, Int. J. Mol. Sci. 2012, 13(5), 5528-5541

10 Lúcia Carvalho Pinto de Melo et all, Materiais Avançados 2010-2022, Centro de Gestão e Estudos Estratégicos, Brasília DF 2010. Pg 307

11 Jong-Choul Shin, Jung-Man Doh, Jin-Kook Yoon, Dok-Yol Lee, Jae-Soo Kim, Effect of molybdenum on the microstructure and wear resistance of cobalt-base Stellig alloys, Korea, Surface and Coatings Technology 166(2003) 117-126 
12 TEAGUE, J; CERRETA, E; STOUT, M. Tensile Properties and Microstructure of Haynes 25 Alloy after Aging at Elevated Temperatures for Extended Times, Los Alamos, Met Mat Trans A Volume 35A, 2004 September

13 P.PONCIN; C. MILLET; J. CHEVY; J.L. PROFT., Comparing and Optimizing CoCr Tubing for Stent Applications, Mat Proc for Dev 25-27 August 2004

14 John T. Scales, G. D. Winter, H. T. Shirley, Corrosion of orthopaedic implants, Journal of Bone and Joint Surgery, London, November 1959

15 Glossary of terms, disponível em< http://www.cts.usc.edu/zglossary-stent.html> acessado em 24 setembro de 2013

16 Lúcia Carvalho Pinto de Melo et all, Materiais Avançados 2010-2022, Centro de Gestão e Estudos Estratégicos, Brasília DF 2010. Pg 307

17 Hand Held Stent Crimping Tools , disponível em <http://www.machinesolutions.com/Stent-Crimping-Medical-ManufacturingEquipment/Stent-Crimping-HH100-HH200.htm > acessado em 16/04/2014

18 V. Kuzucu, M. Ceylan, K. Celik, I. Aksoy, Phase investigation of a cobalt base alloy containing $\mathrm{Cr}, \mathrm{Ni}, \mathrm{W}$ and $\mathrm{C}$, Journal of Materials Processing Technology 74(1998) 137-141 november 1996

${ }_{19}$ P. Poncin, B. gruez, P. Missilier, P. comte-Gaz. L605 preciptates and their effects on stent applications, Proceedings of the Materials \& Processes for Medical Devices Conference, (2005) 14 a 16, Pg 85 a 90

20 .A. GROGAN; S.B. LEEN; P.E. MCHUGH. Comparing Coronary Stent Material Performance on a Common Geometric Platform Though Simulated Bench Testing, Galway J Mech Bio Mat 12 (2012)

${ }^{21}$.R. DAVIS. ASM Speciality Handbook, Nickel, Cobalt, and Their Alloys. ASM International, Pg 340 december 2000

22 J.V. GIACCHI; O. FORNARO; H. PALACIO; Microstructural evolution during solution treatment of $\mathrm{Co}-\mathrm{Cr}-\mathrm{Mo}-\mathrm{C}$ biocompatible alloys, Tandil, Materials Characterization, Volume 68, June 2012, Pages 49-57

${ }^{23}$ W.H. Jiang, H.R. Guan, Z.Q. Hu , Effects of heat treatment on microstructures and mechanical properties of a directionally solidified cobalt-base superalloy, Material Science and Engineering A721 (1999) 101-108

24 T. Hryniewicz, R. Rokicki , K. Rokosz, Co-Cr alloy corrosion behaviour after electropolishing and "magnetoelectropolishing" treatments, Materials Letters 62 (2008) 3073-3076 science direct 
${ }^{25}$ S. Virtanen, I. Milos, E. Gomez-Barrena, R. Trebs, J. Salo , Y.T. Konttinen, Special modes of corrosion under physiologica and simulated physiological conditions, acta Biomaterialia 4 (2008) 468-476

${ }^{26}$ Barry O'Brien, William Carrol, The evolution of cardiovascular stent materials and surfaces in response of clinical drivers: A review, Acta Biomaterialia 5 (2009) 945958

${ }^{27}$ Serrus PW, de Jaegere P, Kiemeneij F, Macaya C, Rutch W, Heyndricx G, et Al. A Comparison of balloon-expandable-stent implantation with balloon angioplasty in patients with coronary artery disease. Benestent Study Group. NEngl J Med. 1994;331(8):489-95

${ }^{28}$ Fichman DL, Leon MB, baim DS, Shatz RA, Savage MP, Penn I, et al. A randomized comparison of coronary-stent placement and balloon angioplasty in the treatment od coronary artery desase. Stent Restenosis Study investigators. N Engl J Med. 1994;331(8):496-501

29 Topol EJ. Coronary-artery stents: gauging, gorging, and gouging.N Engl J Med. 1998;339(23):1702-4

30 Daniel Chamié, Alexandre Abizaid, Stent Cronus: Chegou o momento de adotarmos um stent nacional?, São Paulo, Ver Bras Cardiol Invas. 2009;17(3);3004

31 Adnan Kastrati, Julinda Mehilli, Josef Dirschinger, Franz Dotzer, Helmut Schühlen,Franz-Josef Neumann, Martin Fleckenstein, Conrad Pfafferott, Melchior Seyfarth, Albert Schömig, Intracoronary Stenting and Angiographic Results: Strut Thickness Effect on Restenosis Outcome, Circulation. 2001;103:2816-2821

${ }^{32}$ Rittersma S, de Winter R, Piek J, et al. Impact of strut thickness on late luminal loss after coronary artery stent placement. American Journal Of Cardiology . February 15, 2004;93(4):477.

33 R.V. MARREY; R. BURGERMEISTER; R. B. GRISHABER, R.O. RITCHIE. Implant Device Design Dased on Failure not Survival: A Damage-Tolerant Analysis of a Cardiovascular Stent, Med Device Materials III, Boston, Massachusetts, USA. November 14-16, 2005

${ }^{34}$ RAMESH V. MARREY; ROBERT BURGERMEISTER; RANDY B. GRISHABER; R.O. RICHIE. Fatigue and Life Prediction for Cobalt-Chromium stents: a Fracture Mechanics Analysis, Warren biomaterials 27 (2006) 1988-2000

35 J.A. Grogan, S.B. Leen, P.E. McHGugh, Influence of statistical size effects on the plastic deformation of coronary stents, Galway, Ireland, Journal of the mechanical behavior of Biomedical Materials 20 (2013) 6i-76 
${ }^{37}$ DINA O. HALWANI; PETER G. ANDERSON; BRIGITTA C. BROTT; ANDREAS S. ANAYIOTOS; JACK E. LEMONS. The role of vascular calcification in inducing fatigue and fracture of coronary stents. Birmingham J Biomed Behav Mat, jan 2012 vol 100b, issue 1.

38 CATETERISMO CARDÍACO, Angioplastia com stent, http://www.mdsaude.com/2010/12/cateterismo-cardiaco-angioplastia-stent.html, Acessado em 14/04/2014

39 Standard Test Methods for Tension Testing of Metallic Materials, ASTM E8/E8M - 11, American Association State Highway and Transportation Officials Standard. 2009

$40 \quad$ Grain Structure Types, disponível em < http://www.metallography.com/types.htm> acessado em 6 de abril de 2012

${ }^{41}$ R. W. Armstrong, On size effects in polycristal plasticity, London, J. Merh. Phys. Solids, 1961, Vol. 9, pp. 196 to 199.

${ }^{42}$ X.X. Chen , A.H.W. Ngan, Specimen size and grain size effects on tensile strength of microwires, Scripta Materialia 64 (2011) 717-720

${ }^{43}$ P. PONCIN, J. PROFT. Stent Tubing: Understanding the Desired Attributes, Mat Proc Med Dev 8-10 September 2003

${ }^{44}$ J.R. DAVIS. ASM Speciality Handbook, Nickel, Cobalt, and Their Alloys. ASM International, Pg 350 december 2000. 